\title{
EQUIPAMENTO EXPERIMENTAL PARA DETERMINAÇÃO DE ISOTERMAS DE ADSORÇÃ̃O DE FARINÁCEOS
}

\author{
ANA CLÁUdIA CHESCA
}

Orientador: Prof. Dr. LUIZ GONZAGA DO PRADO FILHO

Dissertação apresentada à Escola Superior de Agricultura "Luiz de Queiroz", da Universidade de São Paulo, para obtenção do tútulo de Mestre em Ciências, Área de Concentração: Ciência e Tecnologia de Alimentos.

PIRACICABA

Estado de São Paulo - Brasil

Setembro de 1995 
Dadas Internacionais de CAtalogação na Ablicação (CIP) DIVISÃO DE BIRLIOTECA E IOIMENIAGÃO - Campus "Luiz de Qeiroz"

Chesca, Ana Clária

Equipanento exprimental para determinaçã de istermas de adłurçä de farinácans. Piracicaba, 1995.

65. ilus.

Diss. (Mestre) - ESALQ

Biblicgrafia.

1. Farima - Teunlagia 2. Farima - Umidade de equilibrio Deteminação I. Escolla Sperior de Agrioultura Luciz de QReiroz, Piracicaba, $\mathbb{S P}$

CD 664.7207 


\title{
EQUIPAMENTO EXPERIMENTAL PARA DETERMINAÇÃO DE ISOTERMAS DE ADSORÇÃ̃O DE FARINÁCEOS
}

\author{
ANA CLÁUdIA CHESCA
}

Aprovada em: 30/11/1995

Comissão Julgadora:

Prof. Dr. Luiz Gonzaga do Prado Filho - ESALQ/USP

Prof. Dr. Marco Antonio Azeredo Cesar - ESALQ/USP

Prof. Dr. Hugo Ghelfi Filho - ESALQ/USP

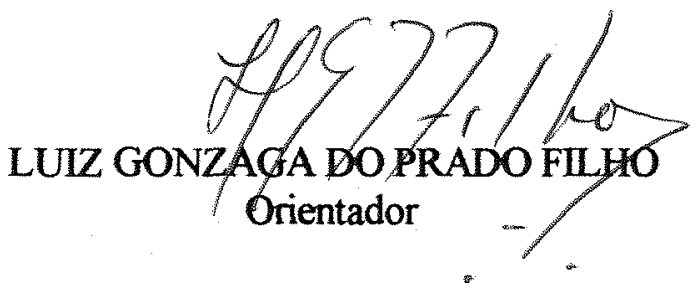


Aos meus pais e ao meu irmão DEDICO 


\section{AGRADECIMENTOS}

- À DEUS, pelo dom da vida;

- À Escola Superior de Agricultura "Luiz de Queiroz" e ao Departamento de Ciência e Tecnologia Agroindustrial, às bibliotecárias Beatriz Giongo e Mídian Gustinelli e ao funcionário Sr. Constante Cristofoletti;

- Ao Prof. Dr. Luiz Gonzaga do Prado Filho pela orientação;

- À Fundação de Amparo à Pesquisa do Estado de São Paulo pela bolsa concedida;

- À Universidade do Tocantins;

- Aos amigos Ricardo, Cristianny, Lilian e Hilkias. 


\section{ÍNDICE}

RESUMO

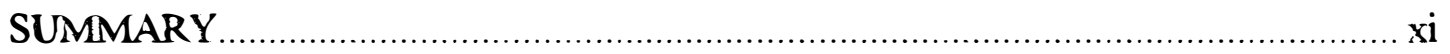

1. INTRODUÇÃO

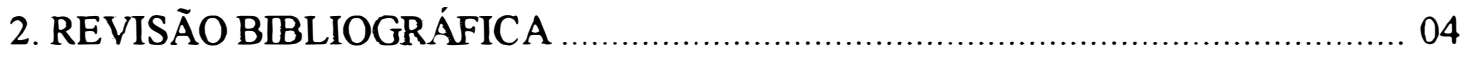

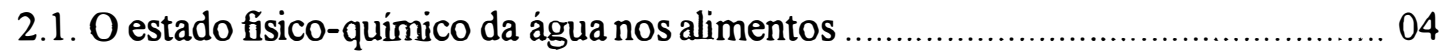

2.2. Determinação da atividade de água em alimentos ........................................ 05

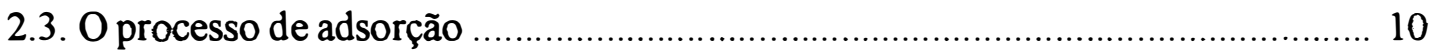

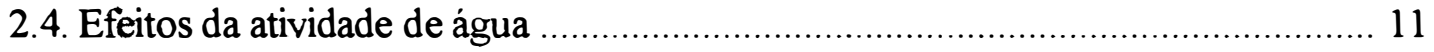

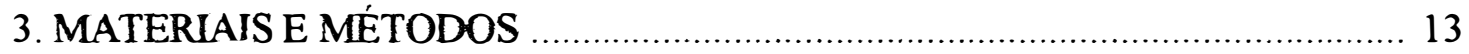

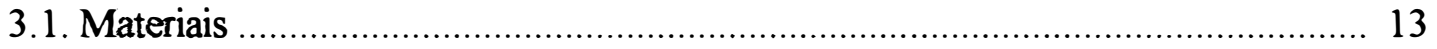

3.1.1. Equipamento experimental utilizado para a obtenção de isotermas parciais de adsorção ........................................................................... 13

3.1.2. Sementes de soja, fubá Mimoso e farinha de mandioca ....................... 16

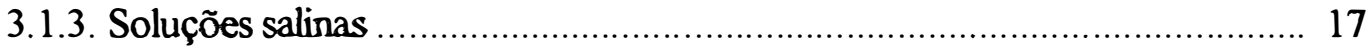

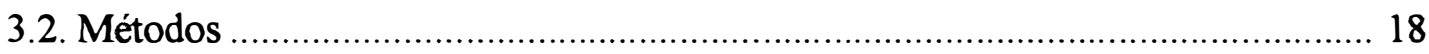

3.2.1. Preparo das faninhas de soja integral e sem casca ...................................18

3.2.2. Determinação dos pontos para o traçado das isotermas parciais ................20

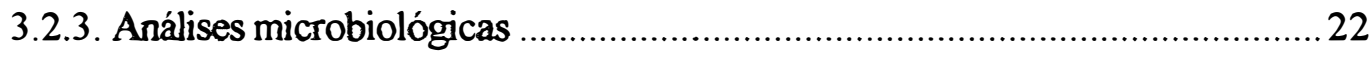

4. RESULTADOS E DISCUSSÃO

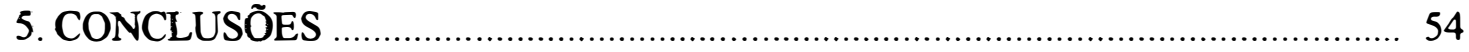

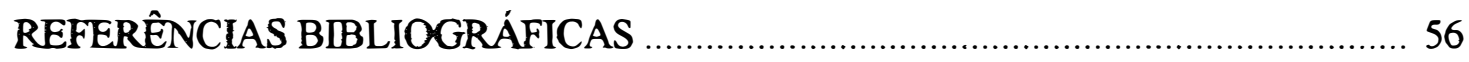

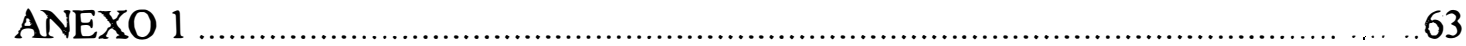




\section{INDICE DE FIGURAS}

Pág.

Figura 1. Câmara de equilibrio - vista lateral com detalhe de dispositivo de ajuste de umidade

Figura 2. Torre de umidificação 15

Figura 3. Fluxograma do processo de fabricação da farinha de soja (KELLOR, 1974) . 19

Figura 4. Torre de umidificação 23

Figura 5. Câmara de equilíbrio com as amostras . 24

Figura 6. Tempo necessário para equilíbrio. Fubá Mimoso $30^{\circ} \mathrm{C}$ reciclado 25

Figura 7. Tempo necessário para equilíbrio. Fubá Mimoso $30^{\circ} \mathrm{C}$ não reciclado . 25

Figura 8. Tempo necessário para equilibrio. Fubá Mimoso $35^{\circ} \mathrm{C}$ reciclado 26

Figura 9. Tempo necessário para equilíbrio. Fubá Mimoso $35^{\circ} \mathrm{C}$ não reciclado 26

Figura 10. Tempo necessário para equilíbrio. Fubá Mimoso $40^{\circ} \mathrm{C}$ reciclado 27

Figura 11. Tempo necessário para equilíbrio. Fubá Mimoso $40^{\circ} \mathrm{C}$ não reciclado 27

Figura 12. Tempo necessário para equilibrio. Farinha de Mandioca $30^{\circ} \mathrm{C}$ reciclada ...... 28

Figura 13. Tempo necessário para equilíbrio. Farinha de Mandioca $30^{\circ} \mathrm{C}$ não reciclada 28

Figura 14. Tempo necessário para equilíbrio. Farinha de Mandioca $35^{\circ} \mathrm{C}$ reciclada ....... 29

Figura 15. Tempo necessánio para equilíbrio. Farinha de Mandioca $35^{\circ} \mathrm{C}$ não reciclada 29

Figura 16. Tempo necessário para equilíbrio. Farinha de Mandioca $40^{\circ} \mathrm{C}$ reciclada ....... 30

Figura 17. Tempo necessário para equilíbrio. Farinha de Mandioca $40^{\circ} \mathrm{C}$ não reciclada 30

Figura 18. Tempo necessário para equilibrio. Farinha Integral de soja Céu Azul $30^{\circ} \mathrm{C}$ reciclada 
Figura 19. Tempo necessário para equilibrio. Farinha Integral de soja Céu Azul $30^{\circ} \mathrm{C}$ não reciclada

Figura 20. Tempo necessário para equilíbrio. Farinha Integral de soja Céu Azul $35^{\circ} \mathrm{C}$ reciclada

Figura 21. Tempo necessário para equilíbrio. Farinha Integral de soja Céu Azul $35^{\circ} \mathrm{C}$ não reciclada

Figura 22. Tempo necessário para equilibrio. Farinha Integral de soja Céu Azul $40^{\circ} \mathrm{C}$ reciclada

Figura 23. Tempo necessário para equilibrio. Farinha Integral de soja Céu Azul $40^{\circ} \mathrm{C}$ não reciclada

Figura 24. Tempo necessário para equilíbrio. Farinha de soja sem casca Céu Azul $30^{\circ} \mathrm{C}$ reciclada

Figura 25. Tempo necessário para equilíibrio. Farinha de soja sem casca Céu Azul $30^{\circ} \mathrm{C}$ não reciclada

Figura 26. Tempo necessário para equilíibrio. Farinha de soja sem casca Céu Azul $35^{\circ} \mathrm{C}$ reciclada

Figura 27. Tempo necessário para equilíibrio.Farinha de soja sem casca Céu Azul $35^{\circ} \mathrm{C}$ não reciclada

Figura 28. Tempo necessário para equilíbrio. Farinha de soja sem casca Céu Azul $40^{\circ} \mathrm{C}$ reciclada

Figura 29. Tempo necessário para equilíibrio. Farinha de soja sem casca Céu Azul $40^{\circ} \mathrm{C}$ não reciclada

Figura 30. Tempo necessário para equilíbrio. Farinha Integral de soja IAC- $0830^{\circ} \mathrm{C}$ reciclada

Figura 31. Tempo necessário para equilíbrio. Farinha Integral de soja IAC-08 $30^{\circ} \mathrm{C}$ não reciclada

Figura 32. Tempo necessário para equilíbrio. Farinha Integral de soja IAC-08 $35^{\circ} \mathrm{C}$ reciclada

Figura 33. Tempo necessário para equilíbrio. Farinha Integral de soja IAC- $0835^{\circ} \mathrm{C}$ não reciclada 
Figura 34. Tempo necessário para equilibrio. Farinha Integral de soja IAC- $0840^{\circ} \mathrm{C}$ reciclada

Figura 35. Tempo necessário para equilibrio. Farinha Integral de soja IAC- $0840^{\circ} \mathrm{C}$ não reciclada

Figura 36. Tempo necessário para equilibrio. Farinha de soja sem casca IAC- $0830^{\circ} \mathrm{C}$ reciclada

Figura 37. Tempo necessário para equilibrio. Farinha de soja sem casca IAC-08 $30^{\circ} \mathrm{C}$ não reciclada

Figura 38. Tempo necessário para equilibrio. Farinha de soja sem casca IAC- $0835^{\circ} \mathrm{C}$ reciclada

Figura 39. Tempo necessário para equilíbrio. Faninha de soja sem casca IAC-08 $35^{\circ} \mathrm{C}$ não reciclada

Figura 40. Tempo necessário para equilibrio. Farinha de soja sem casca IAC- $0840^{\circ} \mathrm{C}$ reciclada

Figura 41. Tempo necessário para equilibrio. Faninha de soja sem casca IAC- $0840^{\circ} \mathrm{C}$ não reciclada

Figura 42. Isotermas parciais de adsorção de fubá Mimoso reciclado a $30^{\circ} \mathrm{C}, 35^{\circ} \mathrm{Ce}$ $40^{\circ} \mathrm{C}$

Figura 43. Isotermas parciais de adsorção de fubá Mimoso não reciclado a $30^{\circ} \mathrm{C}, 35^{\circ} \mathrm{C}$ e $40^{\circ} \mathrm{C}$

Figura 44. Isotermas parciais de adsorção de farinha de mandioca reciclada a $30^{\circ} \mathrm{C}$, $35^{\circ} \mathrm{C}$ e $40^{\circ} \mathrm{C}$

Figura 45. Isotermas parciais de adsorção de farinha de mandioca não reciclada a $30^{\circ} \mathrm{C}$, $35^{\circ} \mathrm{C}$ e $40^{\circ} \mathrm{C}$

Figura 46. Isotermas parciais de adsorção de farinha integral de soja Céu Azul reciclada a $30^{\circ} \mathrm{C}, 35^{\circ} \mathrm{C}$ e $40^{\circ} \mathrm{C}$

Figura 47. Isotermas parciais de adsorção de farinha integral de soja Céu Azul não reciclada a $30^{\circ} \mathrm{C}, 35^{\circ} \mathrm{C}$ e $40^{\circ} \mathrm{C}$

Figura 48. Isotermas parciais de adsorção de farinha de soja sem casca Céu Azul reciclada a $30^{\circ} \mathrm{C}, 35^{\circ} \mathrm{C}$ e $40^{\circ} \mathrm{C}$ 
Figura 49. Isotermas parciais de adsorção de farinha de soja sem casca Céu Azul não reciclada a $30^{\circ} \mathrm{C}, 35^{\circ} \mathrm{C}$ e $40^{\circ} \mathrm{C}$

Figura 50. Isotermas parciais de adsorção de farinha integral de soja IAC-08 reciclada a $30^{\circ} \mathrm{C}, 35^{\circ} \mathrm{C}$ e $40^{\circ} \mathrm{C}$

Figura 51. Isotermas parciais de adsorção de farinha integral de soja não reciclada a $30^{\circ} \mathrm{C}, 35^{\circ} \mathrm{C}$ e $40^{\circ} \mathrm{C}$

Figura 52. Isotermas parciais de adsorção de faninha de soja sem casca IAC-08 reciclada a $30^{\circ} \mathrm{C}, 35^{\circ} \mathrm{C}$ e $40^{\circ} \mathrm{C}$

Figura 53. Isotermas parciais de adsorção de farinha de soja sem casca IAC-08 não reciclada $30^{\circ} \mathrm{C}, 35^{\circ} \mathrm{C}$ e $40^{\circ} \mathrm{C}$ 


\section{ÍNDICE DE TABELAS}

Pág.

Tabela 1. Atividades de água, umidades absolutas na base úmida e base seca dos materiais estudados, antes dos experimentos

Tabela 2. Umidade relativa e atividade de água de soluções salinas saturadas

Tabela 3. Resultado das Análises Microbiológicas 


\title{
RESUMO
}

\section{EQUIPAMENTO EXPERIMENTAL PARA DETERMINAÇĀO DE ISOTERMAS DE ADSORÇĀO DE FARINÁCEOS}

\author{
Autor: ANA CLÁUDIA CHESCA \\ Orientador: Prof. Dr. LUIZ GONZAGA DO PRADO FILHO
}

No presente trabalho, foi realizada a avaliação do desempenho de equipamento experimental, para a determinação prática de curvas de umidade de equilíbrio ou isotermas de adsorção.

O equipamento construído é de baixo custo, de fácil construção e operação, não exigindo ferramentaria e mão-de-obra especializada.

Para o ajuste dos valores de atividade de água (Aa) no interior do equipamento, foram usadas soluções saturadas de sais, abrangendo o âmbito de maior interesse para fins práticos de armazenagem e conservação de materiais particulados, ou seja 0,$51 ; 0,57 ; 0,67 ; 0,75 ; 0,79 ; 0,84 ; 0,91$.

Foram empregadas para a determinação das isotermas de adsorção, farinha de mandioca "Deusa", fubá mimoso "Kitano", farinha integral e sem casca de 
soja das variedades Céu Azul e IAC-08. Foram utilizadas amostras recicladas e não recicladas dessas farinhas.

As isotermas de adsorção desses materiais foram traçadas a $30^{\circ} \mathrm{C}$, $35^{\circ} \mathrm{C}$ e $40^{\circ} \mathrm{C}$

O tempo total de exposição de uma amostra a uma dada Aa foi de 34 horas, com pesagens intermediárias as $10^{\mathrm{a}}, 11^{\mathrm{a}}, 12^{\mathrm{a}}, 24^{\mathrm{a}}, 25^{\mathrm{a}}, 26^{\mathrm{a}}, 27^{\mathrm{a}}, 28^{\mathrm{a}}, 29^{\mathrm{a}}$, $30^{\mathrm{a}}, 31^{\mathrm{a}}, 32^{\mathrm{a}}, 33^{\mathrm{a}}$ e $34^{\mathrm{a}}$ horas.

A partir da última tomada de dado, ou seja, na $34^{\mathrm{a}}$ hora, as amostras eram submetidas às análises microbiológicas, com o objetivo de se determinar a presença de microrganismos amilolíticos.

Observou-se que os tempos necessários para as farinhas utilizadas entrarem em equilibrio, com as atividades de água estudadas, foram sensivelmente mais curtos, da ordem de 10 a 12 horas, quando comparados com métodos estáticos de equilibrio. 


\title{
SUMMARY
}

\section{EXPERIMENTAL EQUIPMENT FOR DETERMINATION OF ADSPRPTION ISOTHERMS OF VARIOUS FLOURS}

\author{
Author: ANA CLÁUDIA CHESCA \\ Adviser: Prof. Dr. LUIZ GONZAGA DO PRADO FILHO
}

In the actual work the performance evaluation of an experimental equipment for practical determination of moisture equilibrium curves or adsorcion isotherms were carried out.

The built equipment is inexpensive, of easy constructuion and operation, so that it does not need specialized tools or manocuvre.

Salt satured solutions were used to adjust the water activity (Aw) inside the equipament, compresing the highest scope of values in practical storage and conservation of particulated material, which are 0,$51 ; 0,57 ; 0,67 ; 0,75 ; 0,79 ; 0,84$ and 0,91 .

In order to determine the adsorption isotherms, "Deusa" manihot flour, "Kitano" corn meal, whole and coreless soybean floury from Céu AzuI and IAC08 cultivars. Recycled and non- recycled samples of these flours were used. 
The adsorption isotherms of these materials were taken at $30^{\circ} \mathrm{C}$, $35^{\circ} \mathrm{C}$ and $40^{\circ} \mathrm{C}$.

The total exposition time of the samples to a given Aw was 34 hours with intermediary weightings at the $10^{\text {th }}, 11^{\text {th }}, 12^{\text {th }}, 24^{\text {th }}, 25^{\text {th }}, 26^{\text {th }}, 27^{\text {th }}, 28^{\text {th }}, 29^{\text {th }}, 30^{\text {th }}$, $31^{\text {s }}, 32^{\text {nd }}, 33^{\text {rd }}$ and $34^{\text {rd }}$ hours.

After the last data taking, which was at the $34^{\text {th }}$ hour, the samples were submitted to microbiological analysis, in order to determine the presence of search degradating microrganisms. It has been observed that necessary time to settle the equilibrium between the testd flours and the studied water activities (Aw) were sensibly shorter, ranging from 10 to 12 hours, when compared to static equilibrium methods. 


\section{INTRODUÇÃO}

Ponderavelmente, a água é, em quase todos os alimentos e matérias primas, um dos mais importantes componentes. De seu teor dependerão a consistência, o aspecto e mesmo a cor do alimento. Também, a água influi no crescimento microbiano, nas reações enzimáticas, oxidação de lipídios, hidrólise e escurecimento não enzimático, assim como em fenômenos de ordem física, como a cristalização e a retrogradação, que podem ocorrer nos alimentos.

Atualmente, a moderna tecnologia do processamento e armazenamento, preocupa-se em evitar alteraçōes favorecidas pela umidade natural das matérias primas e alimentos, controlando-a, seja através de sua eliminação, ou através do emprego de técnicas que a tornem indisponível para reações físico-químicas e biologicas nos supra citados sistemas.

A disponibilidade de umidade em quaisquer sistemas não é quantificada pela umidade absoluta do mesmo, mas sim, pela umidade relativa (UR\%) ou, atividade de água (Aa) que reina nos mesmos.

As relações entre Aa de um sistema (biológico ou não) e a umidade absoluta do mesmo são reproduzidas, graficamente, através das curvas de umidade de equilibrio ou isotermas de adsorção. A isoterma de adsorção de um material qualquer 
define, também, os valores onde a umidade desse material está em equilîbrio com a umidade do ambiente onde o material está localizado, isto é, os pontos onde não há troca de umidade entre o sistema e o ambiente.

O conhecimento e a compreensão das isotermas de adsorção são de grande importância, tanto na área de Tecnologia como na de Ciência dos Alimentos, para a resolução de problemas, tais como: avaliação e caracterização do tipo da ligação da água com o substrato, otimização de processos de produção, avaliação de problemas de armazenamento e embalagem, estimativa de estabilidade física, química e microbiológica dos alimentos, etc (SPIESS \& WOLF, 1983).

O método mais difundido para obtenção de isotermas de adsorção (ou dessorção) de um produto alimentício, é o que utiliza dessecadores contendo soluções saturadas de sais com atividades de água definidas e constantes, para uma dada temperatura.

O presente trabalho teve por objetivo a construção de um protótipo de um equipamento que permitisse a determinação prática e rápida de isotermas parciais de adsorção de matérias primas e alimentos particulados, dentro do âmbito de atividade de água que interessa para fins práticos de armazenagem e conservação, ou seja, entre atividade de água 0,51 e 0,91.

O equipamento montado é de baixo custo, de fácil operação, não exigindo treinamento específico para a operação. Ele é também de fácil construção. E dispensando ferramentaria e mão-de-obra especializadas. 
Para testar e comprovar a aplicabilidade do equipamento montado para a obtençāo de isotermas de materiais particulados, foram usados os seguintes materiais: farinhas de soja das variedades Céu Azul e IAC-08, integral e sem casca, ambas desengorduradas, farinha de mandioca e fubá Mimoso. 


\section{REVISĀO BIBLIOGRÁFICA}

\subsection{O estado físico-químico da água nos alimentos}

A molécula da água, é de natureza fortemente polar por causa da distribuição assimétrica das cargas positivas e negativas e, por isso, apresenta a marcante tendência a ligar-se de diferentes maneiras, seja por pontes de hidrogênio, por forças capilares, ou com iontes (UBOLDI-EIROA, 1981; BOBBIO, 1985).

Pode-se concluir que há pelo menos dois tipos de água em um alimento: um em que se denomina água livre - a água fracamente ligada ao substrato e entre si, e que funciona como solvente em reações permitindo crescimento de microrganismos e, que é eliminada com relativa facilidade. $\mathrm{O}$ outro tipo, a água combinada, fortemente ligada ao substrato, mais difícil de ser eliminada e, que não é utilizável por microrganismos e nem como solvente (KARMAS, 1973; SCOTT \& BERNARD, 1983; BOBBIO, 1985).

Apesar do termo "água combinada" ainda não estar bem definido pelos pesquisadores, um dos critérios mais comuns é o fato dela não ser congelável. Outras propriedades incluem baixa pressão de vapor, alta energia de ligação, não 
disponibilidade como solvente, reduzida mobilidade molecular e mudanças nas propriedades dielétricas quando comparada com a água livre (LEUNG, 1981).

Controlar a água presente nos alimentos é uma das práticas mais antigas de preservação (PRIOR, 1979), sendo que este controle leva em consideração somente a água livre disponível.

O teor de água livre pode ser controlado pela sua remoção por secagem, solidificação por congelamento ou pela adição de eletrólitos como $\mathrm{NaCl}$ ou não eletrólitos, como a sacarose. A adição destes solutos faz com que menos moléculas de água estejam disponíveis para os microrganismos e, devido à deficiência em água livre, estes suspendam suas atividades. Assim, o alimento torna-se estável sob o ponto de vista microbiano (QUAST \& TEIXEIRA NETO, 1975; ANAGNOSTOPOULOS, 1979).

\subsection{Determinação da atividade de água em alimentos}

A medida da atividade de água está baseada nas propriedades coligativas das soluções. Os métodos empregados podem ser complexos ou simples, dispendiosos ou não (TROLLER, 1983).

PRIOR (1979), os classifica a partir de dois tipos de medidas:

1 - Medida de abaixamento do ponto de congelamento de uma solução e posterior conversão em valores de Aa. 
2 - Medida de umidade relativa de equilíbrio (URE) de um sólido ou líquido; neste caso os métodos subdividem-se em métodos que utilizam instrumentos comuns de laboratório e os que utlizam equipamentos especiais.

A medida do ponto de congelamento pode ser feita utilizando-se um termômetro com sensibilidade de $\pm 0,1^{\circ} \mathrm{C}$. A amostra é resfriada num banho de álcool numa temperatura abaixo de $0^{\circ} \mathrm{C}$ e o congelamento induzido pela adição de um cristal de gelo na solução super resfriada. Este método é mais adequado para se determinar a atividade de água em soluções com Aa acima de 0,8 e baseia-se na lei de Raoult, a qual afirma que o abaixamento do ponto de congelamento de uma solução está diretamente relacionada com a diminuição da pressão de vapor da solução comparada com a da água pura na mesma temperatura e pressão. A pressão de vapor da solução (P) é obtida em tabelas a partir do abaixamento do ponto de congelamento e a atividade de água é calculada dividindo-se a pressão de vapor da solução pela pressão de vapor da água pura (Po) (PRIOR, 1979).

Uma outra maneira de se calcular a Aa, segundo FETT (1973), baseia-se numa forma da lei de Raoult a qual afirma qua a pressão de vapor do solvente numa solução (P) dividida pela pressão de vapor do solvente puro (Po) é igual a fração molar do solvente na solução:

$$
\text { Aa }=\underset{\text { Po }}{-\frac{P}{--}}=\text { fração molar do solvente }=\frac{N_{1}}{-N_{1}+N_{2}}
$$


Onde: $\mathrm{N}_{1}=$ número de moles do solvente, e $\mathrm{N}_{2}=$ número de moles do soluto e pode ser determinado a partir do abaixamento do ponto de congelamento e a partir da seguinte equação:

$$
\mathrm{N}_{2}=\frac{\mathrm{G} T f}{2000 \mathrm{Kf}}
$$

Sendo $\mathrm{G}=$ gramas do solvente usados na preparação, $\mathrm{Tf}=$ abaixamento do ponto de congelamento em ${ }^{\circ} \mathrm{C}, \mathrm{Kf}=$ constante molal do abaixamento do ponto de congelamento (para a água, $\mathrm{Kf}=1,86$ ).

Dentre os métodos de determinação de umidade relativa de equilibrio que utilizam instrumentos comuns de laboratório, os métodos das isotermas de adsorção de umidade é o mais simples, o melhor e, o que oferece maior precisão. Neste método, amostras do alimento exatamente pesadas são colocadas em dessecadores, contendo soluções saturadas de sais com Aa conhecida. Atingindo o equilibrio nas amostras (peso constante), é determinado, nas amostras, os teores de umidade absoluta correspondentes às atividades de água dos sais empregados. Os pares de valores obtidos, localizados em a isoterma de adsorção. A partir desta pode-se conhecer a atividade de água de um (sistema) alimento, conhecendo-se a sua umidade absoluta (FETT, 1973)

O método do papel de filtro impregnado, baseia-se no fato de que um sal não se dissolve, a menos que o nível de umidade do ambiente se eleve até o ponto em que iguala o conteúdo de umidade de saturação do sal. Fitas de papel são mergulhadas em várias soluções saturadas de sais e, em seguida, secadas e fixadas no 
interior da tampa de uma placa de Petri. A amostra do alimento é colocada na parte inferior da placa de Petri, que é selada e colocada a $20^{\circ} \mathrm{C} / 20 \mathrm{~h}$, para permitir o estabelecimento do equilibrio. Se a fita absorver umidade, a Aa da amostra é superior a Aa do sal do papel. A Aa da amostra terá um valor compreendido entre a Aa do papel úmido de maior Aa e a Aa do papel seco de Aa mais baixa. A exatidão obtida por este método vai depender da escolha dos sais (DUCKWORTH, 1975).

No método da interpolação gráfica de LANDROCK \& PROCTOR (1951), as amostras são colocadas em atmosferas de umidade relativa conhecida, por um tempo arbitrário, geralmente uma hora. Os valores obtidos de ganho ou perda de massa são colocados num gráfico em função das umidades relativas e, por interpolação, obtêmse a umidade relativa em que ocorre alteração na massa da amostra.

A determinação da Aa por meio de higrômetros de fibra, psicrômetros, métodos manométricos, ponto de orvalho, higrômetros eletrônicos, são amplamente utilizados, porém, exigem instrumentos especiais de laboratórios (AYRANCY, 1990).

GAL (1975), descreve os métodos gravimétricos de determinação de atividade de água onde o princípio e o registro da variação de peso da amostra, podendo ser este registro feito continuamente ou descontínuo, ambos podendo ser estático ou dinâmico, ou seja sem recirculação de ar ou com recirculação de ar do ambiente onde estão as amostras.

LONCIN et al. (1968), usaram um equipamento com recirculação de ar para obter isotermas de um grande número de alimentos. GUR-ARIEH et al. 
(1965) descrevem um equipamento com recirculação de ar, obtendo isotermas de adsorção de 24 a 36 horas. A recirculação propicia o estabelecimento rápido de uma umidade relativa estável na corrente de ar, o que reflete a rapidez com que as amostras atingem o equilibrio.

XAVIER et al. (1986), obtiveram isotermas de adsorção de umidade de blocos salgados, prensados e secos de pescado, utilizando-se dessecadores com diferentes umidades relativas e sem recirculação, totalizando-se 20 dias.

TEIXEIRA NETO \& QUAST (1977), determinaram isotermas de adsorção de 40 alimentos, utilizando-se de dessecadores contendo soluçōes saturadas de sais, empregando o método estático, levando-se em média 8 dias para atingir o equilibrio de umidade nas amostras.

SABBAGH (1985), determinou a umidade de equilibrio em farinhas de sementes oleaginosas, utilizando os métodos de recirculação de ar e sem recirculação de ar. Para os mesmos materiais, o tempo para atingir o equilíbrio para as amostras que se apresentaram em ambiente sem recirculação de ar foi de aproximadamente 105 horas, as amostras em embiente com ar recirculado apresentou equilibrio em aproximadamente 48 horas. Observou-se uma redução bastante significativa de tempo, utilizando-se o método de ar recirculado.

PARK (1992) traçou curvas de equilibrio higroscópico de três genótipos de grão-de-bico, onde o tempo necessário para se atingir a umidade de equilßbrio foi de 56 dias, variando em função do genótipo do grão-de-bico. As amostras permaneceram em dessecadores sem recirculação de ar. 
KIMURA \& MAEDA (1993), construiram isotermas de adsorção de água do alginato de sódio, utilizando-se dessecadores de 500, 250 e $125 \mathrm{ml}$, contendo soluções salinas saturadas de diferentes sais de atividade de água conhecidas. As diferentes dimensões não influenciaram na obtenção das isotermas. O tempo de equilíbrio das amostras foi de aproximadamente 10 dias.

KONTOMINAS (1993), traçou curvas de adsorção de umidade de massa para macarrão convencional e "diet". O tempo de equilíbrio para o método gravimétrico, foi de 3 semanas.

SPIESS \& WOLF (1983) e SPIESS \& WOLF (1987), descrevem um método gravimétrico estático padrão para a obtenção das isotermas de adsorção, objetivando obter dados mais precisos. O projeto foi denominado "COST $90^{n}$. Onde uma isoterma de adsorção padrão da celulose microcristalina foi estabelecida, servindo como material de referência para uma metodologia baseada na utilização de recipientes com solução saturadas de dimensões padronizadas.

\subsection{O processo de adsorção}

O processo de adsorção consiste em 4 etapas de transferência de massa e 3 etapas de transferência de calor; liberação do adsorvato da fonte de adsorvato, transporte do adsorvato para a superfície do produto; adsorção do adsorvato pela superfície do adsorvente e, finalmente, o processo de transporte dentro do adsorvante para os locais onde as moléculas de água estarão ligadas (SPIESS \& WOLF, 1987). 
Dependendo do tipo e composição do produto a incorporação de moléculas de água dentro do alimento pode conduzir à formação de hidratos e/ou soluções, ou géis por inchamento (SALTMARCH \& LABUZA, 1980).

O processo de transferência de calor tem a direção oposta, o calor liberado durante o processo de adsorção é transportado para a superfície do adsorvente, onde é descarregado nos arredores do adsorvente e em alguns casos transmitido para a fonte de adsorvato (BOLIN, 1980).

Termodinamicamente, o processo de sorção é espontâneo (AG < 0), o aumento de temperatura no entanto representa uma condição desfavorável ao processo de sorção de água, pois a temperatura afeta a mobilidade das moléculas de água, fixando-se um certo valor de Aa, observa-se que o produto torna-se menos higroscópico com o aumento da temperatura (BENEDETTI et al., 1987).

\subsection{Efeitos da atividade de água}

\section{Segundo QUAST \& TEIXEIRA NETO (1975) e ALVES \&}

PADULA (1992), o conhecimento da atividade de água é mais importante que o conhecimento do teor de umidade, tanto para a escolha de sistemas adequados de embalagem, como para prever o comportamento de misturas de alimentos com diferentes atividades de água.

LABUZA (1970), afirma que alimentos com baixo teor de Aa, como mel, balas, alimentos desidratados e alguns produtos para panificação, geralmente sofrem 
oxidação mais rápida dos lipídios, por falta de uma camada monomolecular protetora de água.

Os microrganismos apresentam um comportamento bastante diverso em relação à Aa favorável para o seu desenvolvimento, pois seu crescimento e metabolismo exigem a presença de água numa forma disponível, sendo a Aa um índice desta disponibilidade (UBOLDI-EIROA, 1981; LEITĀO et al., 1987).

QUAST \& TEIXEIRA NETO (1975), afirmam que muitos microrganismos podem sobreviver em estado latente, por tempo indeterminado na forma desidratada. Após o restabelecimentos da Aa adequada inicia-se o seu crescimento e multiplicação.

Abaixo de Aa igual a 0.6 não há menção de crescimento de qualquer tipo de microrganismo, sendo o alimento microbiologicamente estável (CHRISTIAN, 1980). 


\section{MATERIAIS E MÉTODOS}

\subsection{Materiais}

3.1.1. Equipamento experimental utilizado para a obtenção de isotermas parciais de adsorção

O protótipo consta de câmara de equilíbrio com equipamentos auxiliares de controle e medição.

A câmara de equilibrio é constituída de uma caixa plástica (Figura 1), comum em comércio, com as seguintes medidas $30 \times 26 \mathrm{~cm}$ e altura $12 \mathrm{~cm}$, dotada de tampa, acoplada à tampa há uma torre de umidificação em contato, na sua extremidade inferior, com uma placa de Petri contendo solução saturada de sal, conforme a Aa desejada no ambiente.

A torre de umidificação (Figura 2), foi construída com um segmento de tubo de PVC com aberturas superiores e inferiores, dotada de um motor de corrente contínua de $12 \mathrm{~V}$ e $2.400 \mathrm{rpm}$, encontrado em estabelecimento do ramo de equipamentos de áudio. O motor aciona hélice com oito pás, construída de folha de cobre de $0,1 \mathrm{~mm}$ de espessura e $30 \mathrm{~mm}$ de diâmetro. 


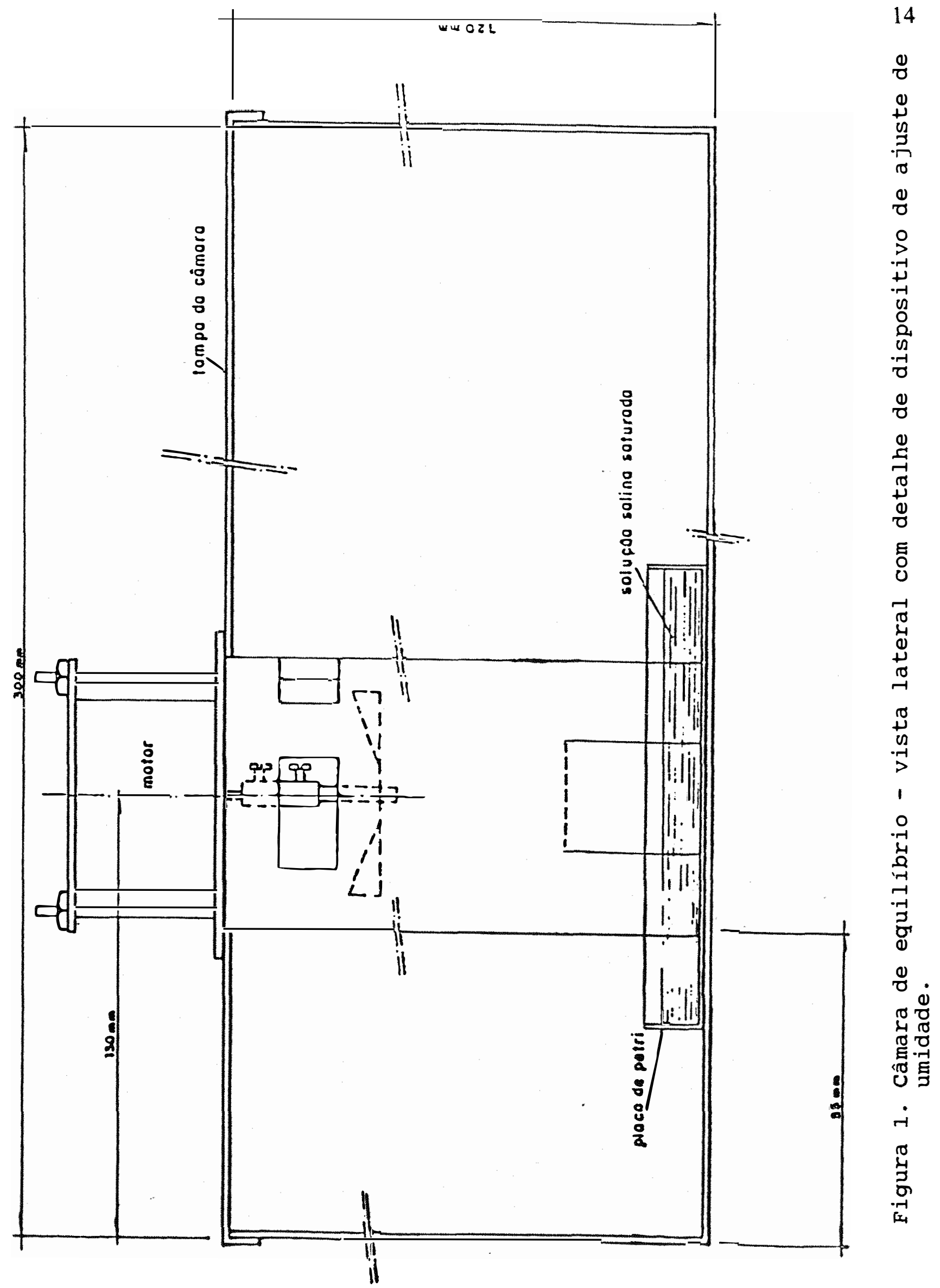




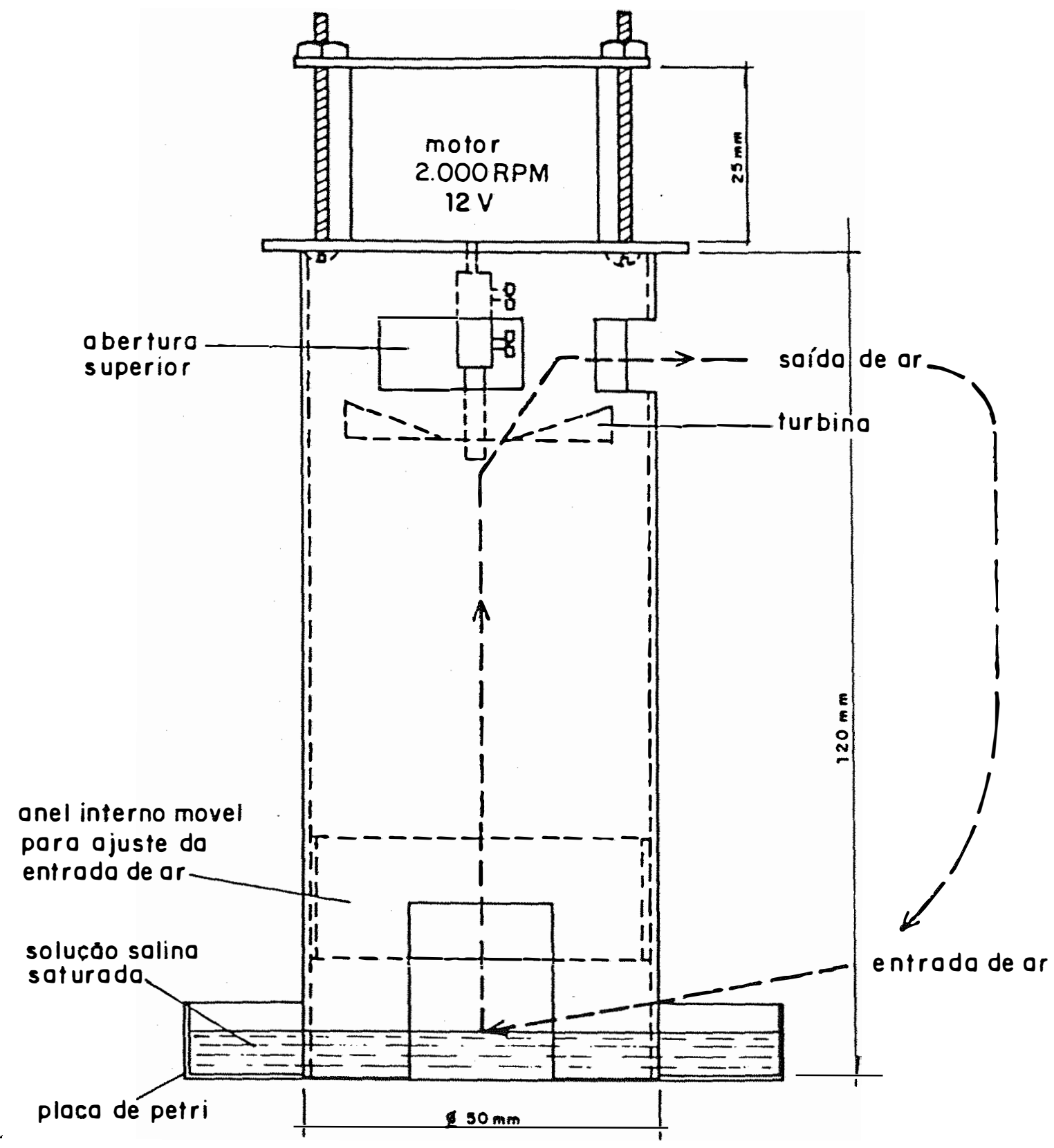

Figura 2. Torre de umidificação. 
As temperaturas desejadas durante os experimentos foram mantidas colocando-se o equipamento montado em estufa marca HERAUS, modelo VT/ $\mathrm{N}_{2}$, com controle eletrônico de temperatura. As operações de pesagens foram realizadas em balança marca SARTORIUS modelo EXCELLENCE E 5500 com precisão de 10mg.

O equipamento foi montado em duplicata. Quando estavam na estufa, permaneciam separados por anéis de PVC.

\subsubsection{Sementes de soja, fubá Mimoso e farinha de mandioca}

As sementes de soja empregadas no preparo das farinhas utilizadas para a execução do presente trabalho são procedentes do Departamento de Genética da Escola Superior de Agricultura "Luiz de Queiroz", da Universidade de São Paulo. As variedades utilizadas foram: IAC-08 e Céu Azul.

A farinha de mandioca, marca Deusa, e o fubá Mimoso, marca Kitano, foram adquiridos em comércio local. As umidades absolutas e as atividades de água dos materais estudados, antes dos experimentos, são mostrados na Tabela 1, a seguir. 
Tabela 1. Atividades de água*, umidades absolutas na base úmida e base seca dos materiais estudados, antes dos experimentos.

\begin{tabular}{|c|c|c|c|}
\hline \multirow[t]{2}{*}{ Material } & \multirow{2}{*}{$\begin{array}{l}\text { Atividade } \\
\text { de água }\end{array}$} & \multicolumn{2}{|c|}{ Umidade absoluta } \\
\hline & & base úmida & base seca \\
\hline Fubá mimoso & 0,381 & 5,59 & 5,92 \\
\hline Farinha de Mandioca & 0,324 & 5,39 & 5,69 \\
\hline $\begin{array}{l}\text { Farinha integral de } \\
\text { soja céu Azul }\end{array}$ & 0,519 & 6,86 & 7,36 \\
\hline $\begin{array}{l}\text { Farinha de soja Céu } \\
\text { Azul, sem casca }\end{array}$ & 0,521 & 6,06 & 6,45 \\
\hline $\begin{array}{l}\text { Farinha integral de } \\
\text { soja IAC-08 }\end{array}$ & 0,534 & 6,75 & 7,23 \\
\hline $\begin{array}{l}\text { Farinha de soja } \\
\text { IAC-08, sem casca }\end{array}$ & 0,548 & 6,84 & 7,34 \\
\hline
\end{tabular}

"Medida com termohigrômetro eletrônico Cole Parmer, precisão $\pm 0,02$

\subsubsection{Soluçōes salinas}

As soluções salinas saturadas utilizadas para ajustar as Aa definidas de equilíbrio das amostras de farinha de soja, fubá Mimoso e farinha de mandioca, são as mencionadas por SMITH (1971), resumidas na Tabela 2, apenas para os valores de umidades relativas estudadas neste trabalho. 
Tabela 2. Umidade relativa e atividade de água de soluções salinas saturadas.

\begin{tabular}{|c|c|c|c|}
\hline \multicolumn{2}{|l|}{ SAL } & \multirow{2}{*}{$\frac{\text { UMIDADE RELATIVA }}{51}$} & \multirow{2}{*}{$\frac{\mathrm{Aa}}{0,51}$} \\
\hline Nitrato de & magnésio & & \\
\hline Brometo de & sódio & 57 & 0,57 \\
\hline Cloreto de & cobre & 67 & 0,67 \\
\hline Cloreto de & sódio & 75 & 0,75 \\
\hline Sulfato de & amônio & 79 & 0,79 \\
\hline Cloreto de & potássio & 84 & 0,84 \\
\hline Nitrato de & potássio & 91 & 0,91 \\
\hline
\end{tabular}

Fonte: SMITH (1971).

\subsection{Métodos}

\subsubsection{Preparo das farinhas de soja integral e sem casca}

O preparo das farinhas de soja integral e sem casca foi executado conforme o esquema apresentado por KELLOR (1974) (Figura 3). As sementes de soja foram selecionadas, quebradas, descascadas (para a obtenção da farinha sem casca), e trituradas para facilitar a extração de óleo, por éter de petróleo fração $30-40^{\circ} \mathrm{C}$ em extrator de Soxlhet, por um período de 18 horas. A farinha assim obtida foi submetida a tratamento térmico a $100^{\circ} \mathrm{C}$ por 30 minutos, para a inativação dos fatores antinutricionais (SMITH \& CIRCLE, 1972). Após este processo, as farinhas passaram por nova moagem e padronização, através de peneira de malha 20 "mesh". 

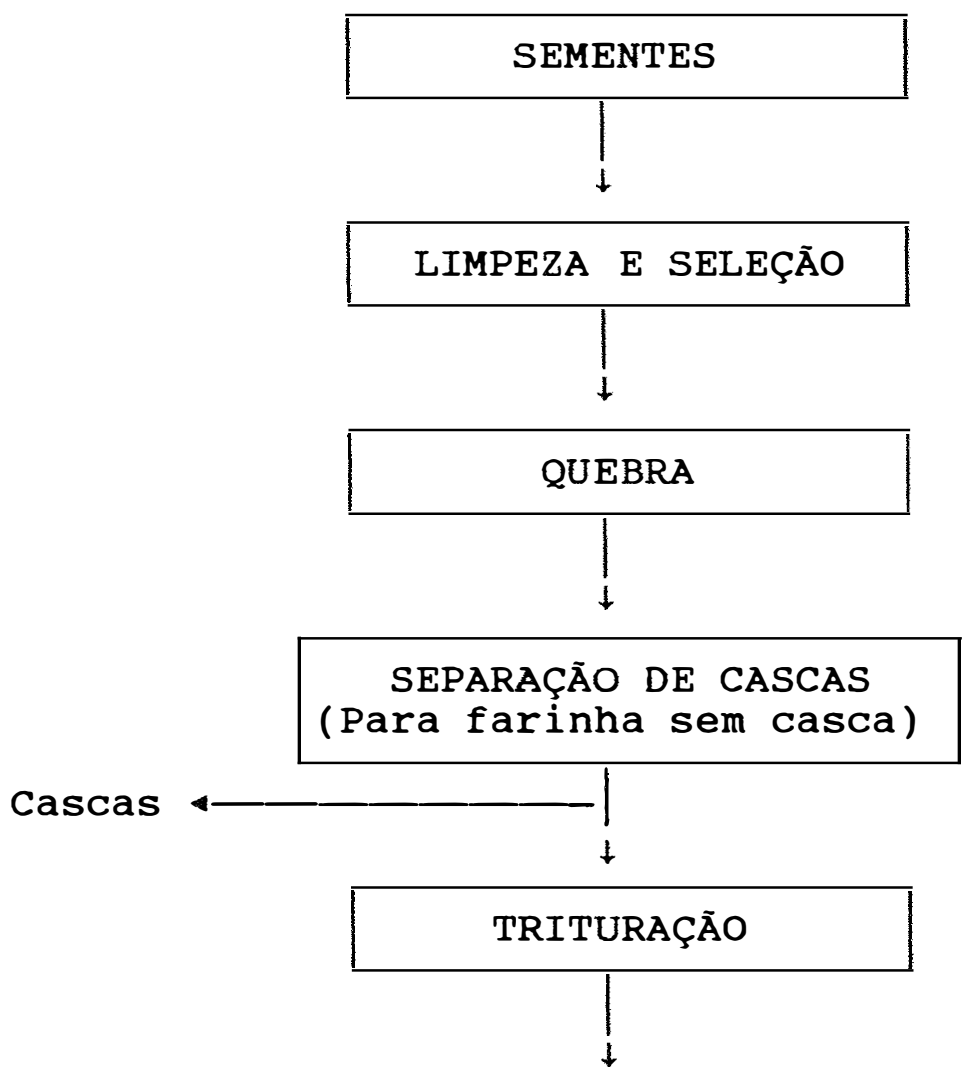

EXTRAÇÃO DE ÓLEO

(Soxlhet, $18 \mathrm{~h}$, éter de petróleo $\mathrm{PE} 30-40^{\circ} \mathrm{C}$ )

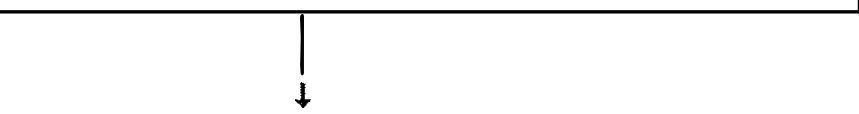

TRATAMENTO TÉRMICO $\left(100^{\circ} \mathrm{C} ; 30 \mathrm{~min}.\right)$

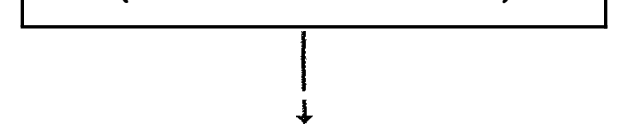

MOAGEM E PADRONIZAÇÃO

(peneira 20 "mesh")

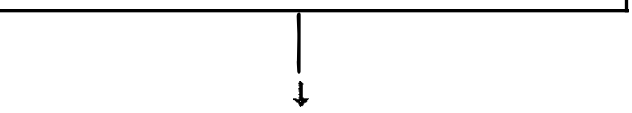

FARINHA

Figura 3. Fluxograma do processo de fabricação da farinha de soja (KELLOR, 1974) 


\subsubsection{Determinação dos pontos para o traçado das isotermas parciais}

Os pontos para o traçado das isotermas parciais das farinhas de soja, de mandioca e do fubá mimoso foram determinados seguindo-se o procedimento descrito a seguir.

Em fundos de placas de Petri de polipropileno, tarados, eram pesadas de 8 a 12 gramas do material a estudar. As placas eram levadas à câmara, esta era fechada, ajustada torre de umidificação e o conjunto levado à estufa sendo feita então, a conecção elétrica do motor.

Este procedimento era repetido para cada Aa e cada temperatura para as amostras não recicladas. Ao fim do período de equilíbrio as amostras eram transferidas para a estufa secadora por 6 horas a $105^{\circ} \mathrm{C}$ (AOAC, 1990), sendo então calculado o teor de água na base seca, no equilibrio. Para as amostras equilibradas no último ponto da isoterma parcial - Aa $=0,91$ - antes da secagem era retirada uma amostra parcial para determinação microbiana, como descrito em 3.2.3.

Para as amostras recicladas, ao fim de cada período de equilibrio era feita uma pesagem para determinação do peso total da amostra (matéria seca mais umidade) para posteriores cálculos da umidade na base seca. As amostras, então, retornavam à câmara já munida da solução saturada correspondente à Aa imediatamente superior, sendo este procedimento repetido até o último valor de Aa desejado. 
Ao fim do último período de equilibrio era feita a determinação da umidade após retirada de amostra para análise microbiológica, sendo o peso retirado considerado nos cálculos finais da umidade na base seca.

Tanto para as amostras recicladas, que eram aquelas que permaneciam no equipamento experimental a cada troca de solução salina, como para as amostras não recicladas, que eram aquelas trocadas a cada troca de solução salina, o tempo de equilíbrio foi de 34 horas, em cada valor de Aa estudado, determinado através de experimentos prévios, como tempo máximo suficiente para o equilibrio dos materiais estudados nas Aa de interesse.

Embora todas as amostras tivessem tido o mesmo tempo total de equilibrio, foram feitas, sistematicamente, pesagens na $10^{\mathrm{a}}, 11^{\mathrm{a}}, 12^{\mathrm{a}}, 24^{\mathrm{a}}, 25^{\mathrm{a}}, 26^{\mathrm{a}}$, $27^{\mathrm{a}}, 28^{\mathrm{a}}, 29^{\mathrm{a}}, 30^{\mathrm{a}}, 31^{\mathrm{a}}, 32^{\mathrm{a}}, 33^{\mathrm{a}}$ e $34^{\mathrm{a}}$ horas, pois, materiais diferentes mostraram tempos de equilibrio diferentes nas Aa estudadas.

As pesagens eram feitas levando-se a câmara para junto da balança. Para cada repetição, a operação de pesagem durava menos que um minuto.

As Figuras 6 a 41, mostram os gráficos de tempos de equilíbrio dos materiais estudados.

Estas operações foram repetidas para as amostras recicladas e não recicladas de cada material nas temperaturas de $30^{\circ} \mathrm{C}, 35^{\circ} \mathrm{C}$ e $40^{\circ} \mathrm{C}$. Obtidos todos os pontos de equilíbrio para uma amostra à cada uma das temperaturas previstas, as isotermas parciais de adsorção foram traçadas com auxílio do editor gráfico Harvard Graphics da SoftWare Publishing Corp., versão 2.30 para microcomputador. 


\subsubsection{Análises microbiológicas}

As análises microbiológicas foram realizadas segundo método descrito por SPECK (1976). Foram feitas diluições até $10^{-8}$.

Após a incubação de 24 horas realizou-se a contagem, a coloração de Gram e coloração de esporos, segundo SPECK (1976), identificando-se os microrganismos predominantes como pertencentes ao gênero Bacillus. 


\section{RESULTADOS E DISCUSSĀO}

As Figuras 4 e 5 mostram, respectivamente a torre de umidificação e câmara de equilibrio, utilizada para a determinação das curvas de adsorção das farinhas.

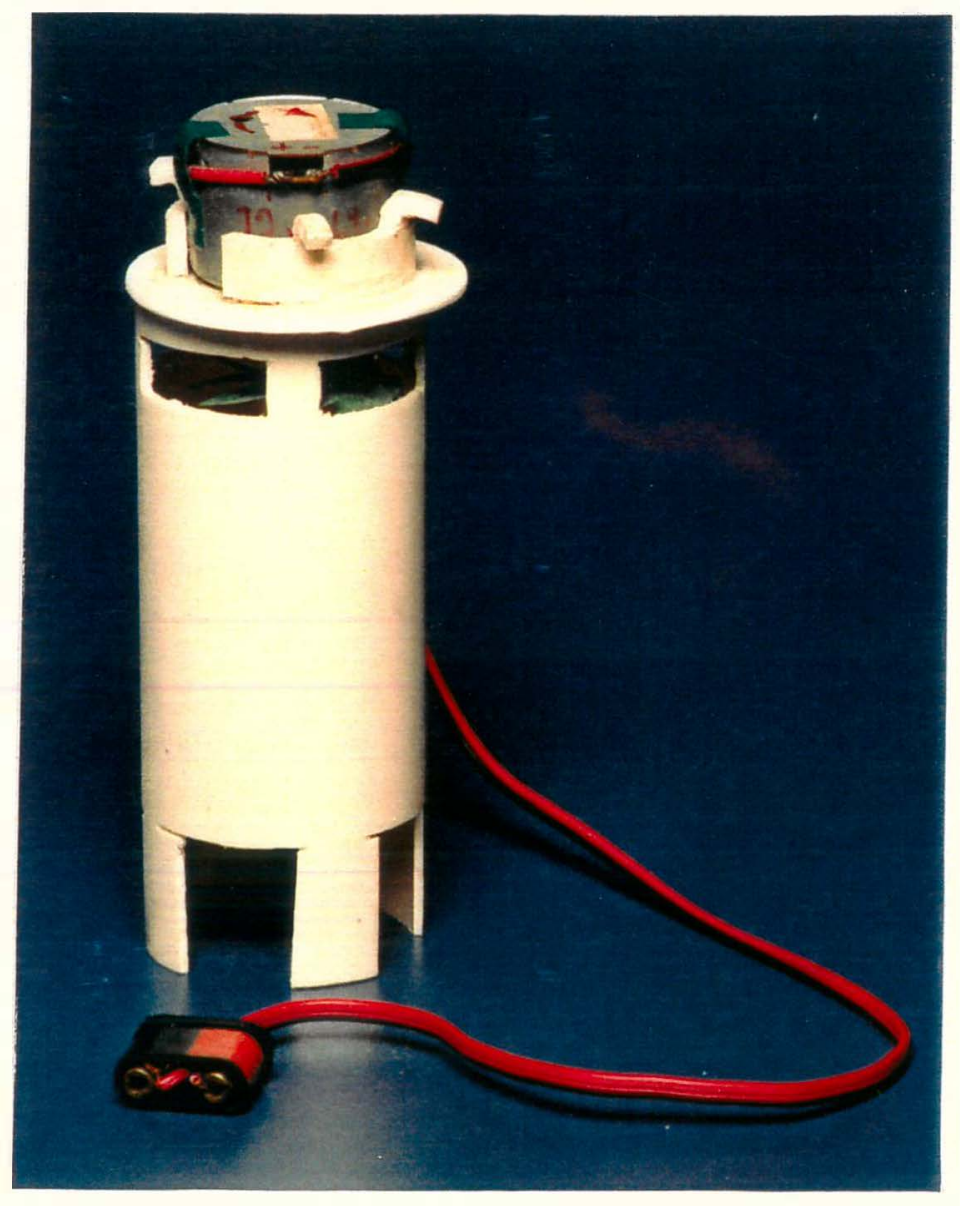

Figura 4. Torre de umidificação. 


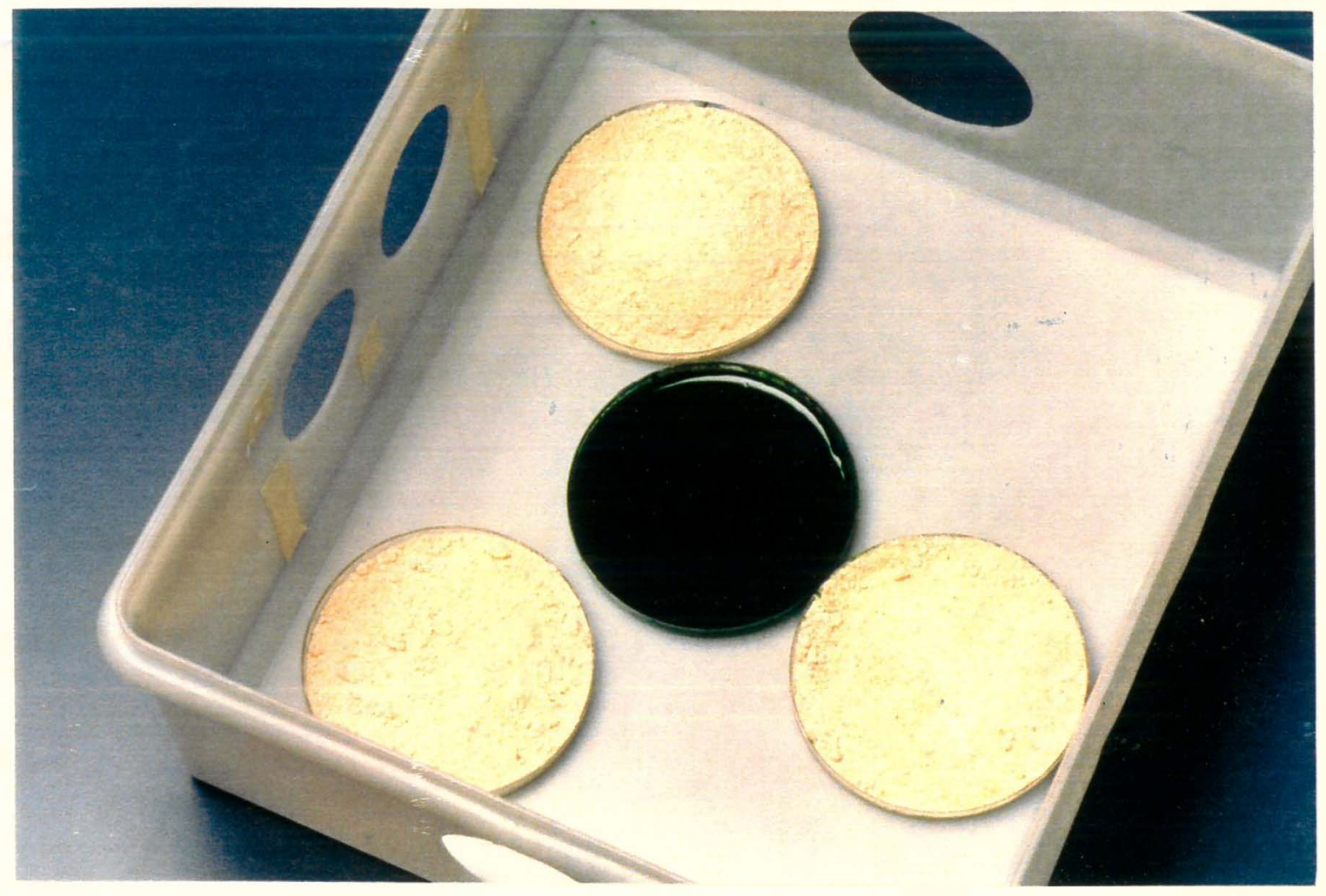

Figura 5. Câmara de equilibrio com as amostras.

As Figuras 6 a 41 mostram o tempo em horas de equilibrio das farinhas para as temperaturas de 30,35 e $40^{\circ} \mathrm{C}$, sendo as amostras recicladas e não recicladas. 


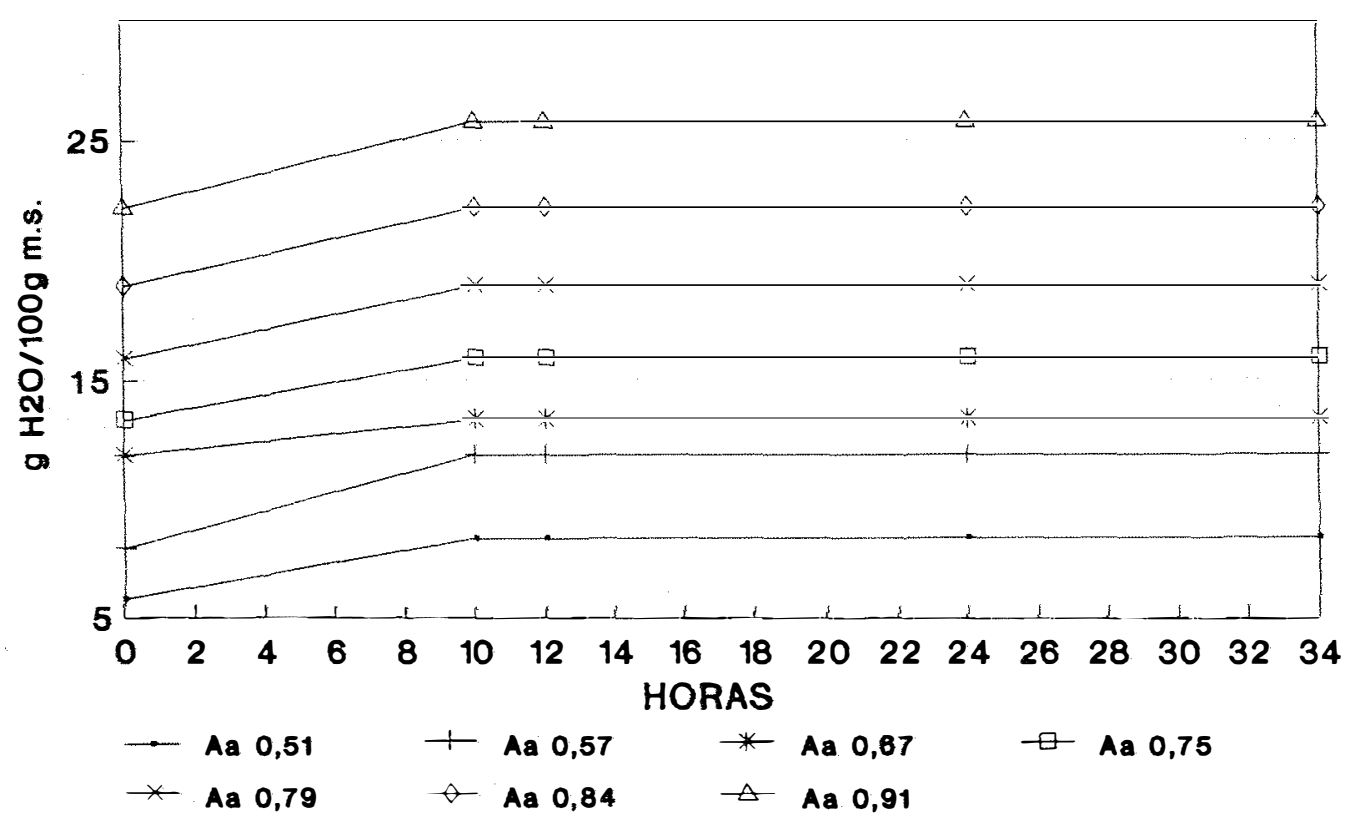

Figura 6. Tempo necessário para equilibrio. Fubá Mimoso $30^{\circ} \mathrm{C}$ reciclado.

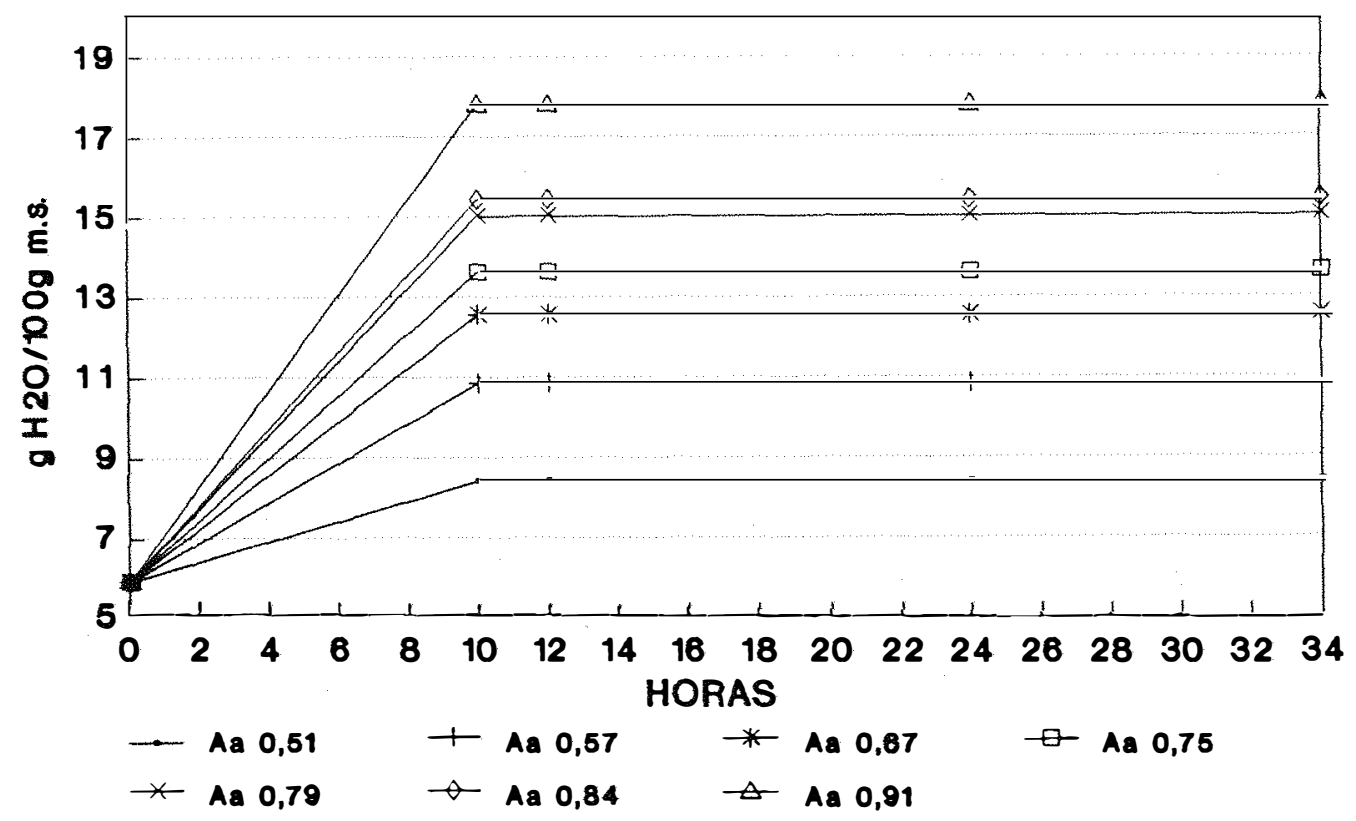

Figura 7. Tempo necessário para equilíbrio. Fubá Mimoso $30^{\circ} \mathrm{C}$ não reciclado. 


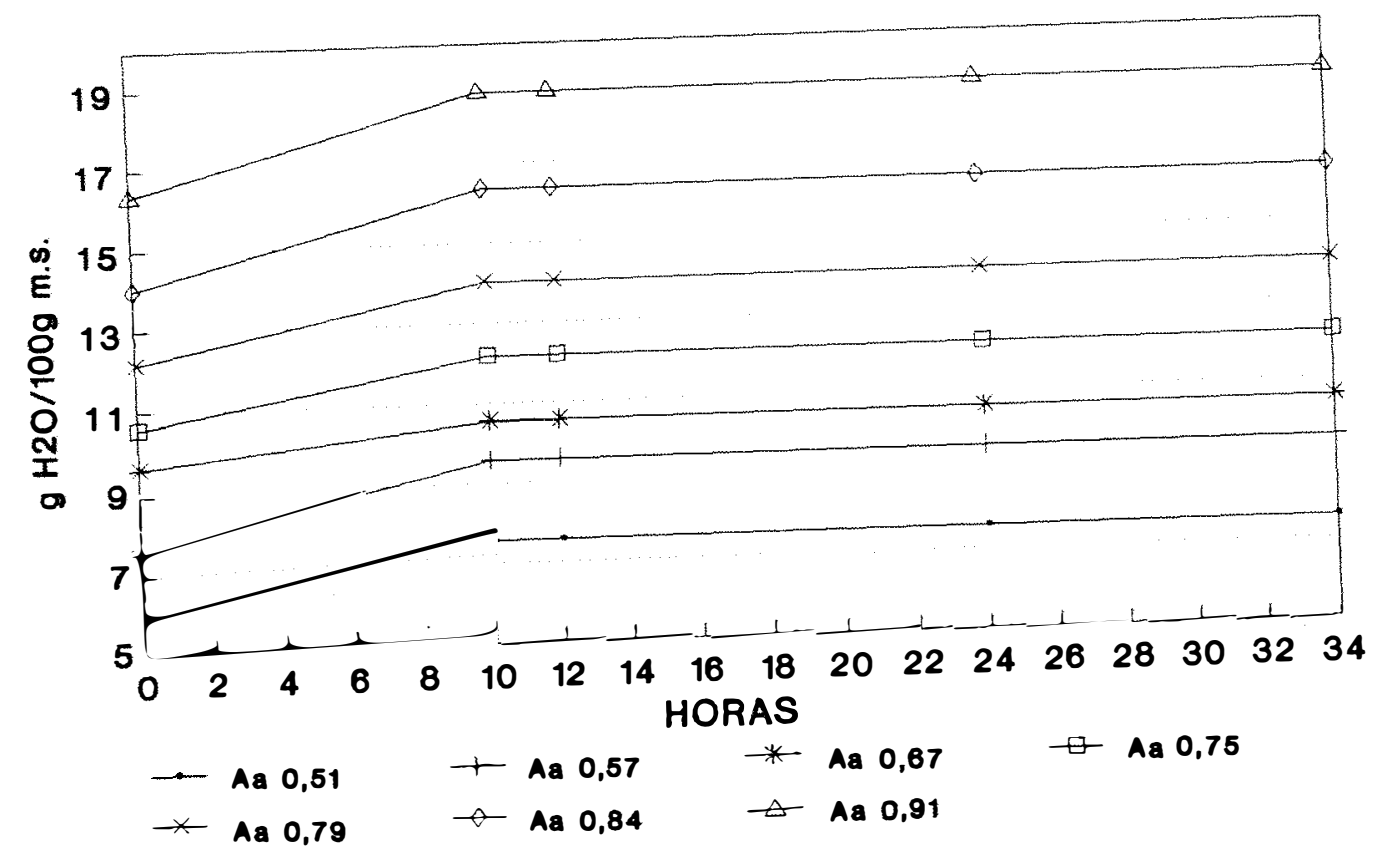

Figura 8. Tempo necessário para equilíbrio. Fubá Mimoso $35^{\circ} \mathrm{C}$ reciclado.

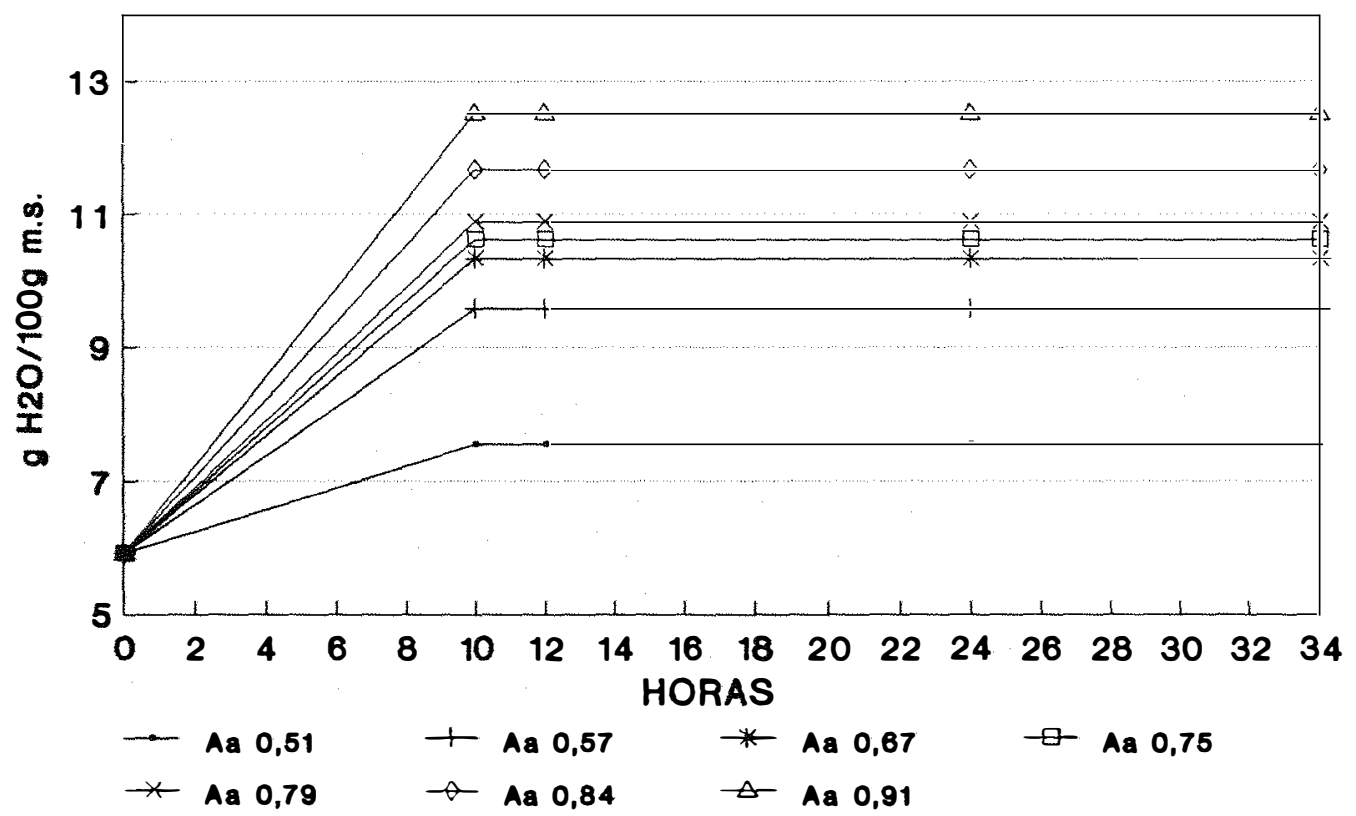

Figura 9. Tempo necessário para equilibrio. Fubá Mimoso $35^{\circ} \mathrm{C}$ não reciclado. 


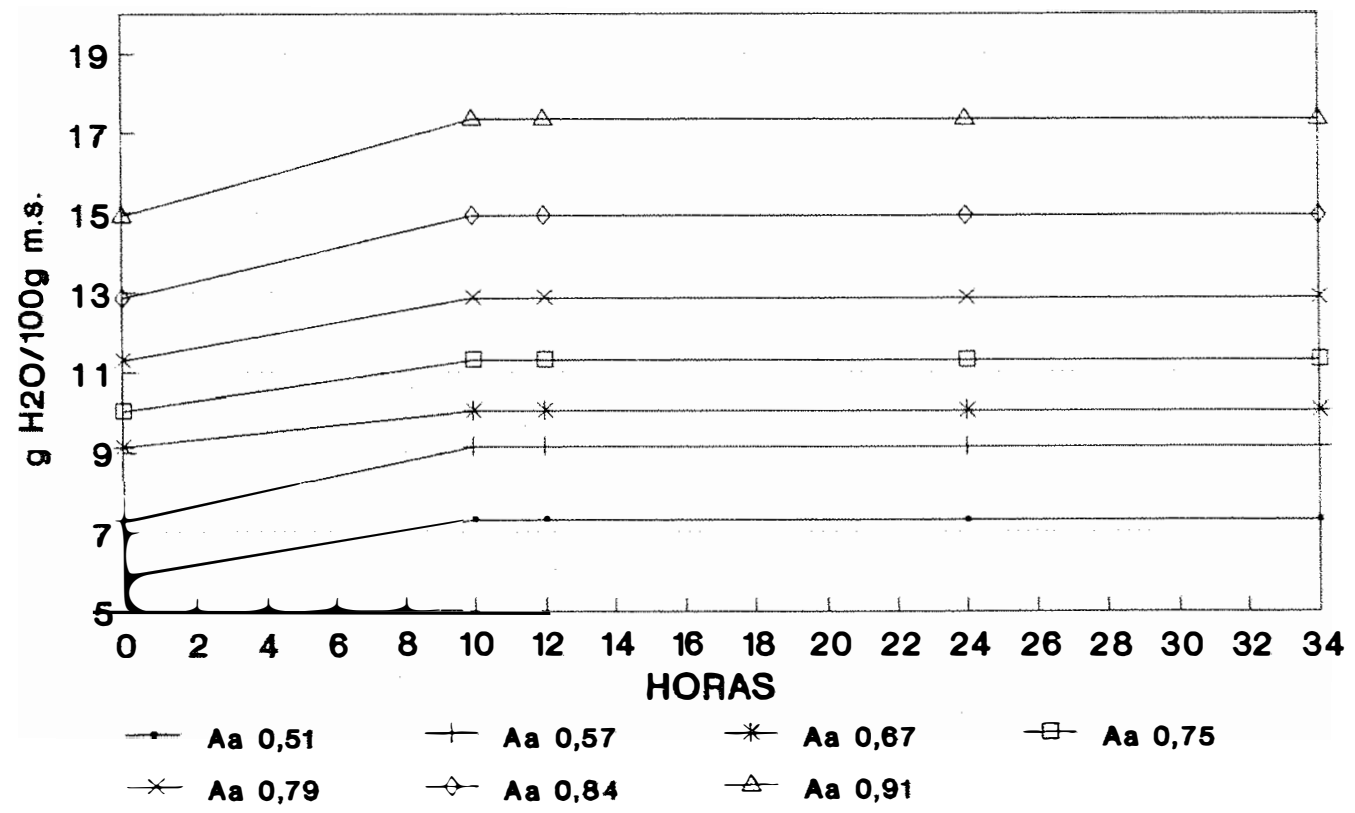

Figura 10. Tempo necessário para equilibrio. Fubá Mimoso $40^{\circ} \mathrm{C}$ reciclado.

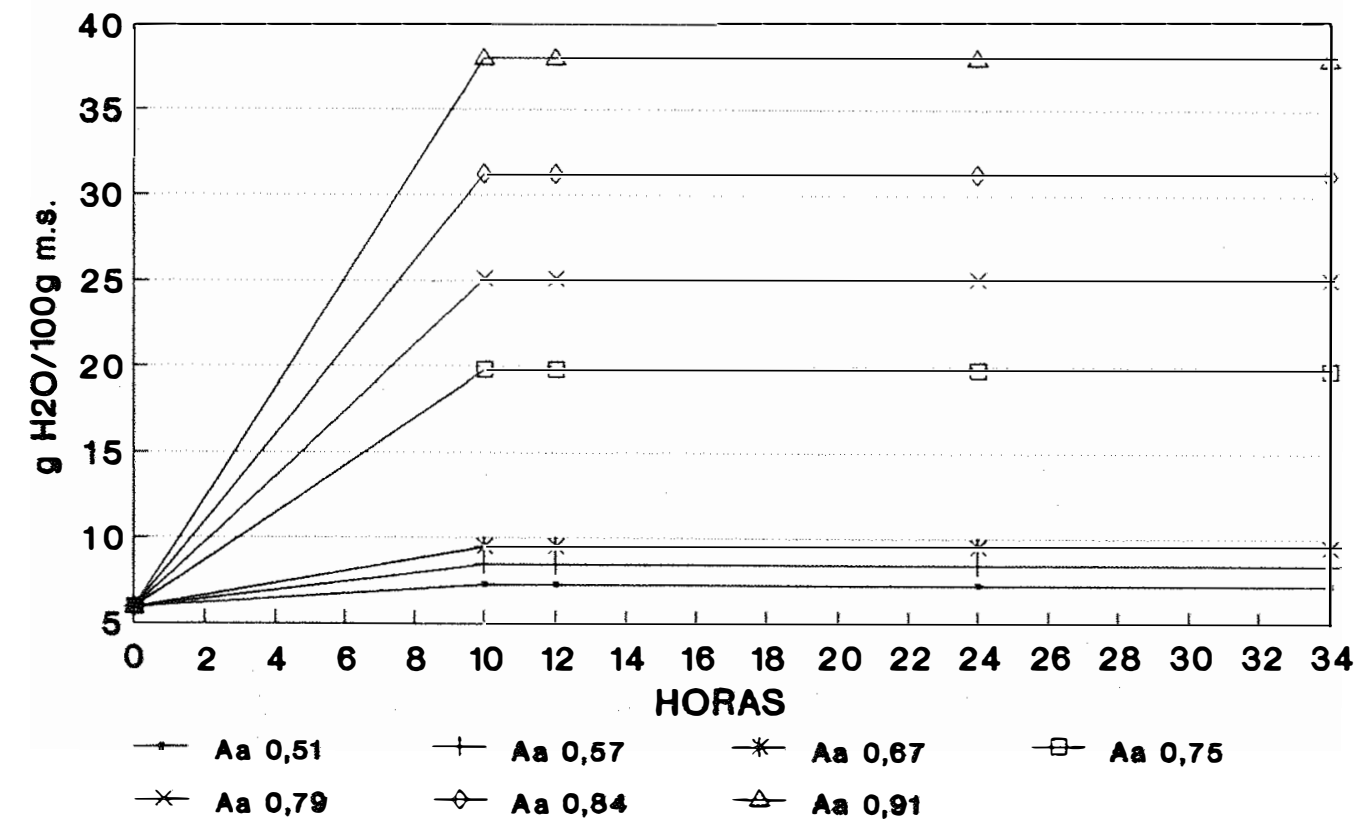

Figura 11. Tempo necessário para equilíbrio. Fubá Mimoso $40^{\circ} \mathrm{C}$ não reciclado. 


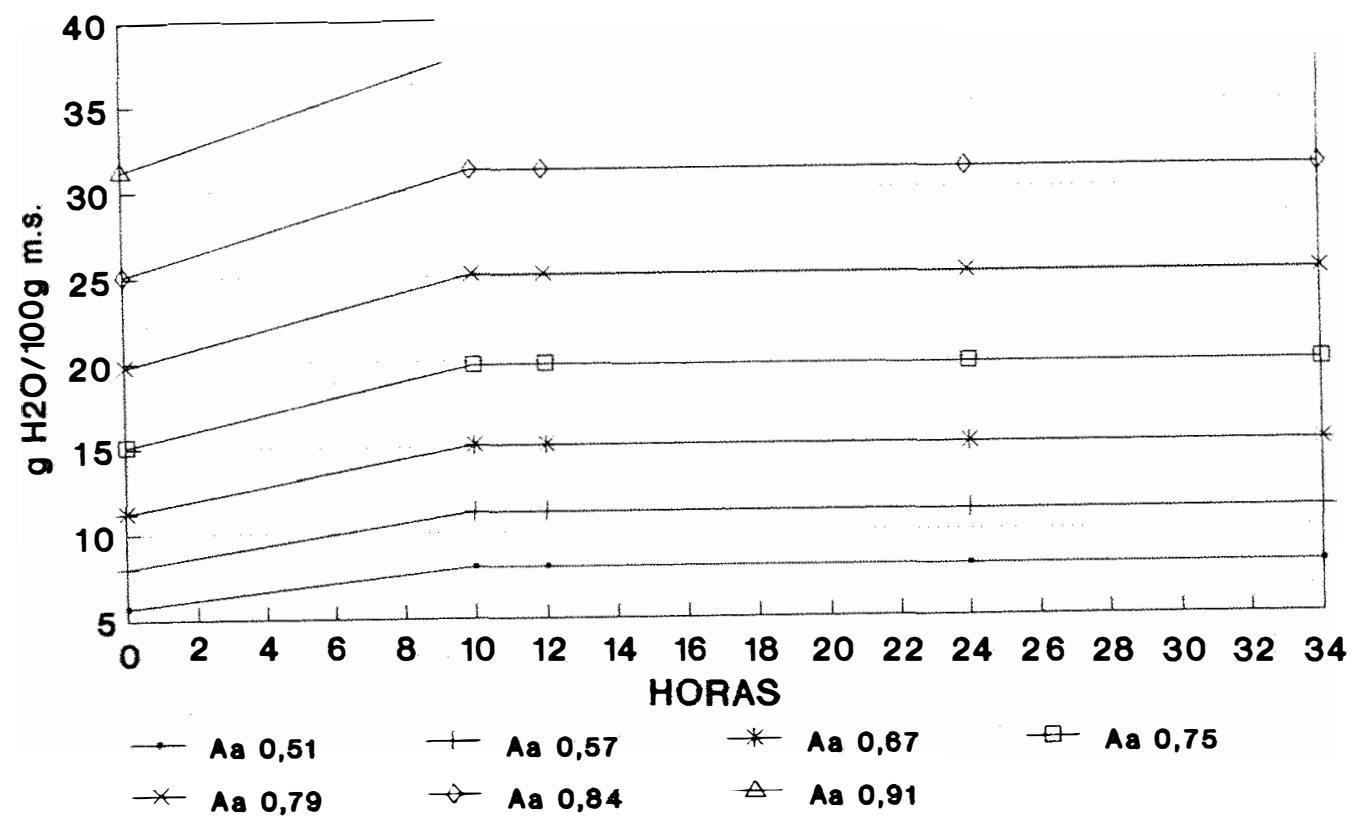

Figura 12. Tempo necessário para equilibrio. Farinha de Mandioca $30^{\circ} \mathrm{C}$ reciclada.

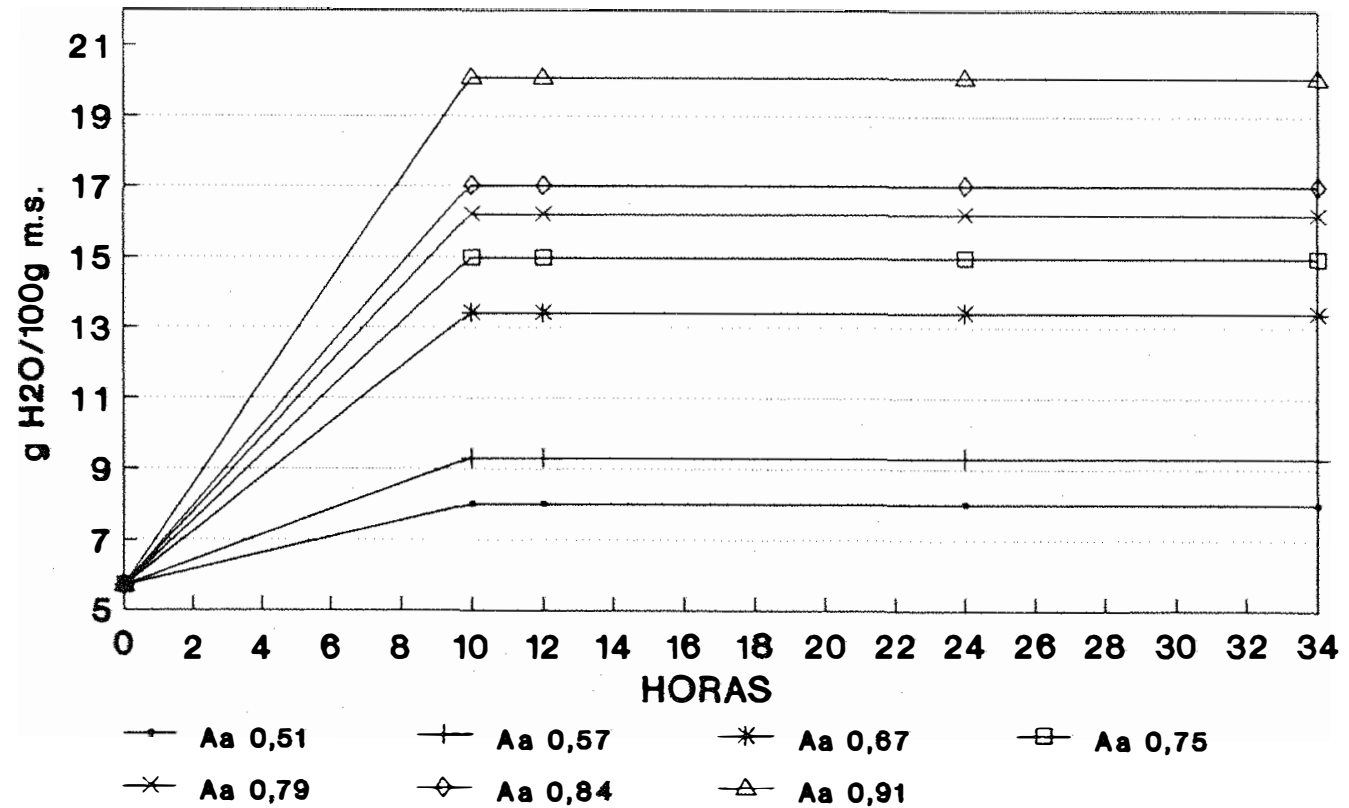

Figura 13. Tempo necessário para equilibrio. Farinha de Mandioca $30^{\circ} \mathrm{C}$ não reciclada. 


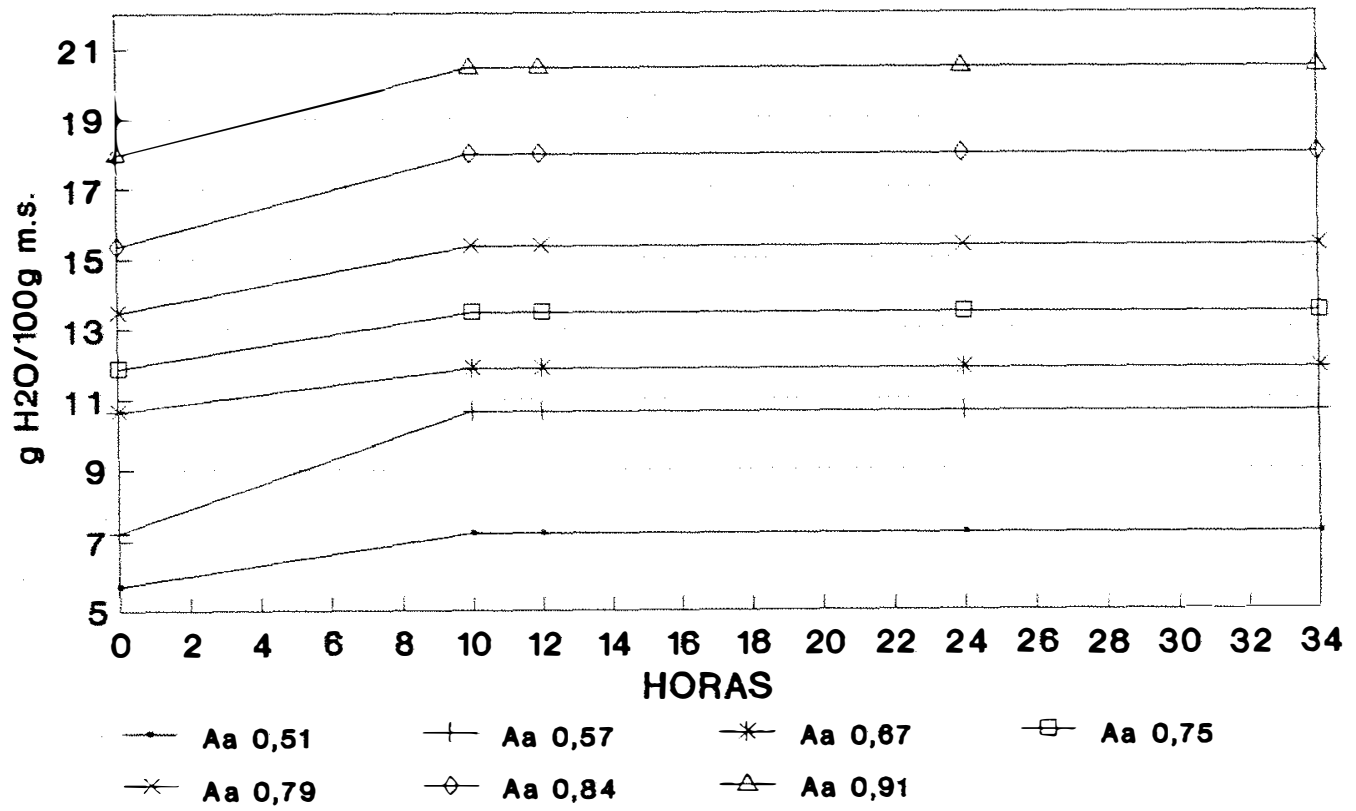

Figura 14. Tempo necessário para equilíbrio. Farinha de Mandioca $35^{\circ} \mathrm{C}$ reciclada.

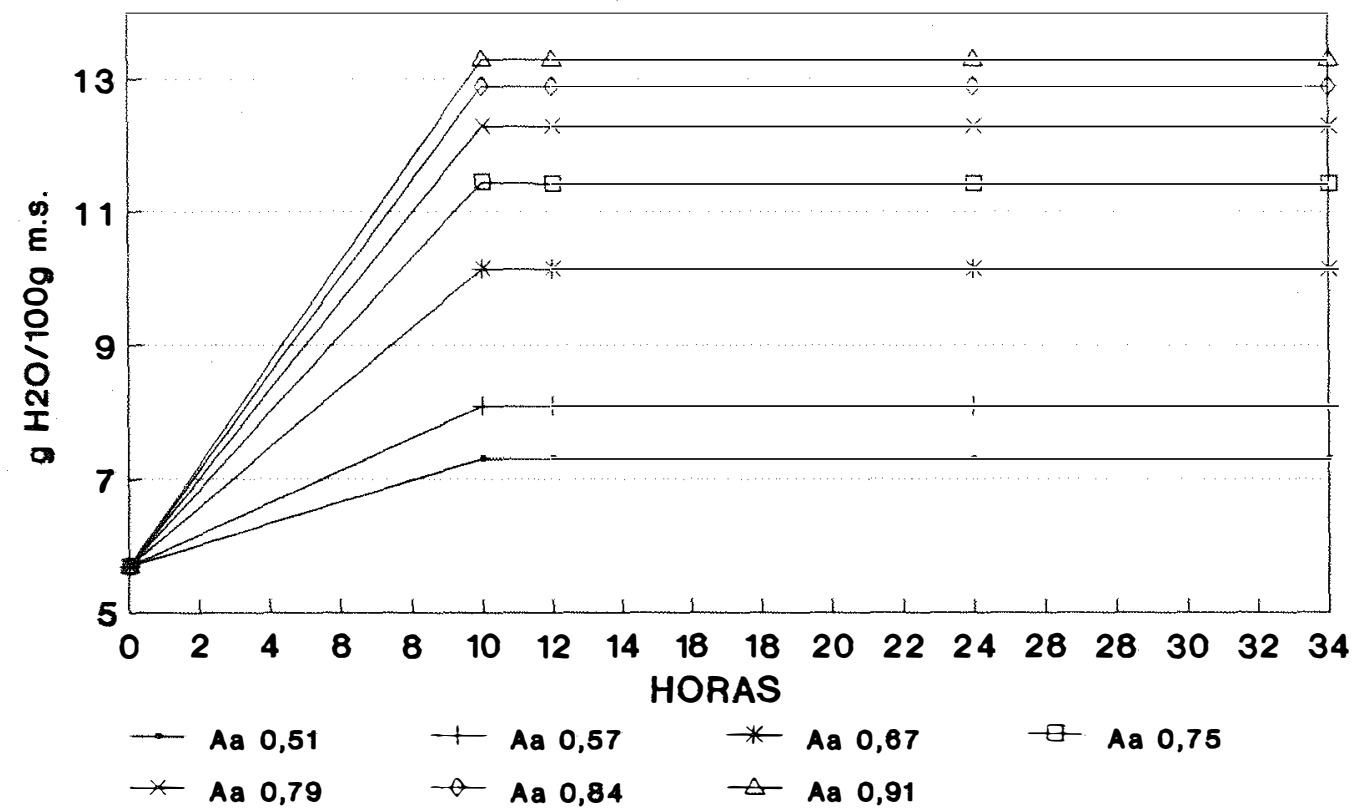

Figura 15. Tempo necessário para equilíbrio. Farinha de Mandioca $35^{\circ} \mathrm{C}$ não reciclada. 


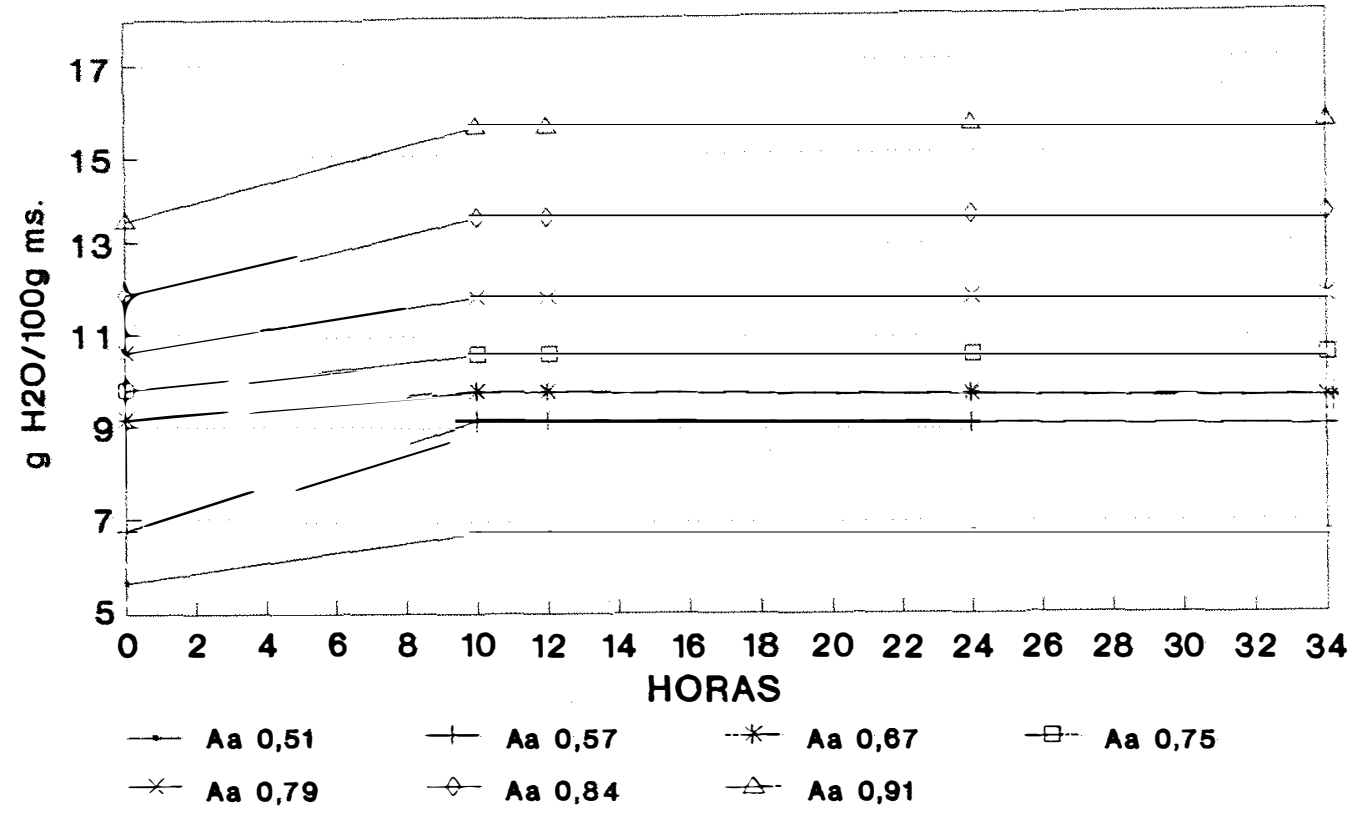

Figura 16. Tempo necessário para equilibrio. Farinha de Mandioca $40^{\circ} \mathrm{C}$ reciclada.

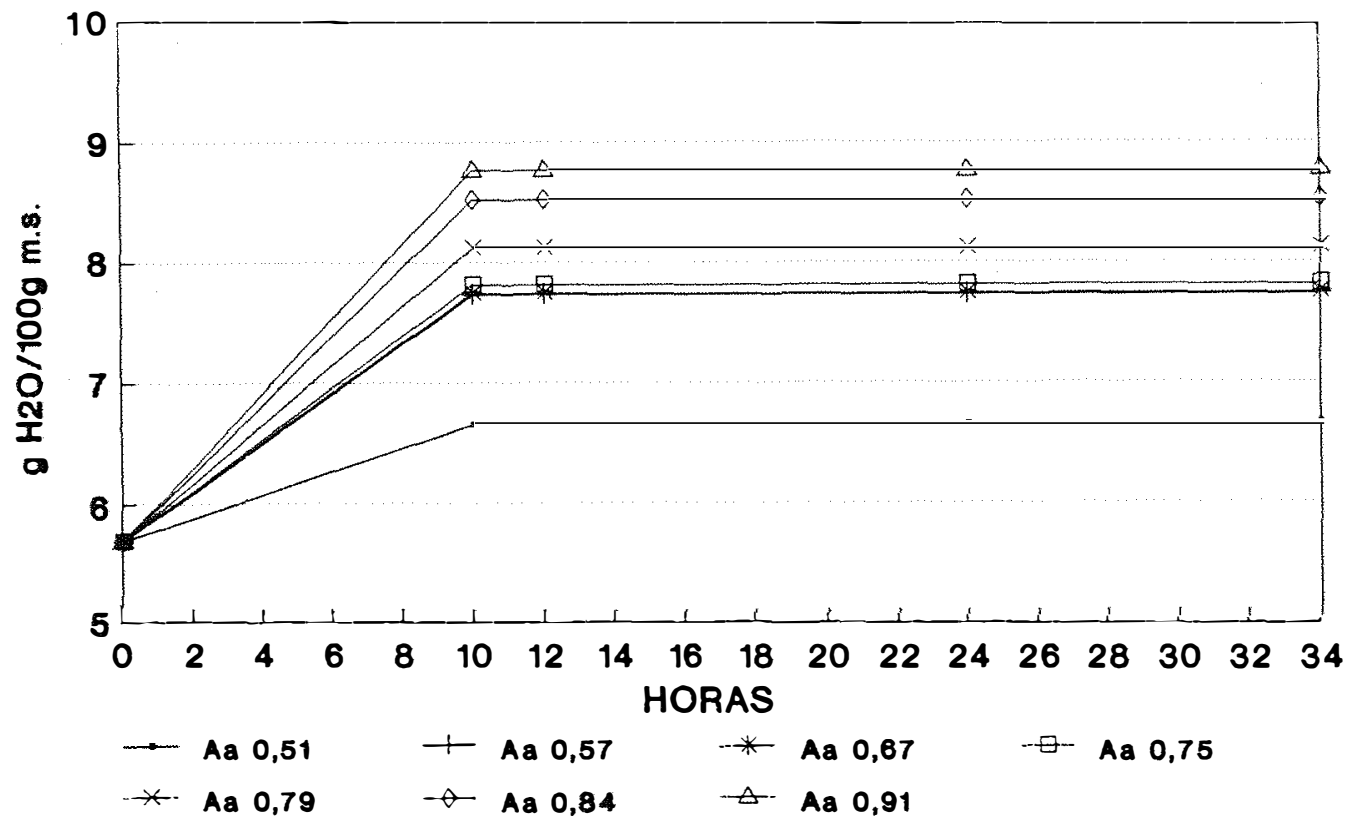

Figura 17. Tempo necessário para equilßbrio. Farinha de Mandioca $40^{\circ} \mathrm{C}$ não reciclada. 


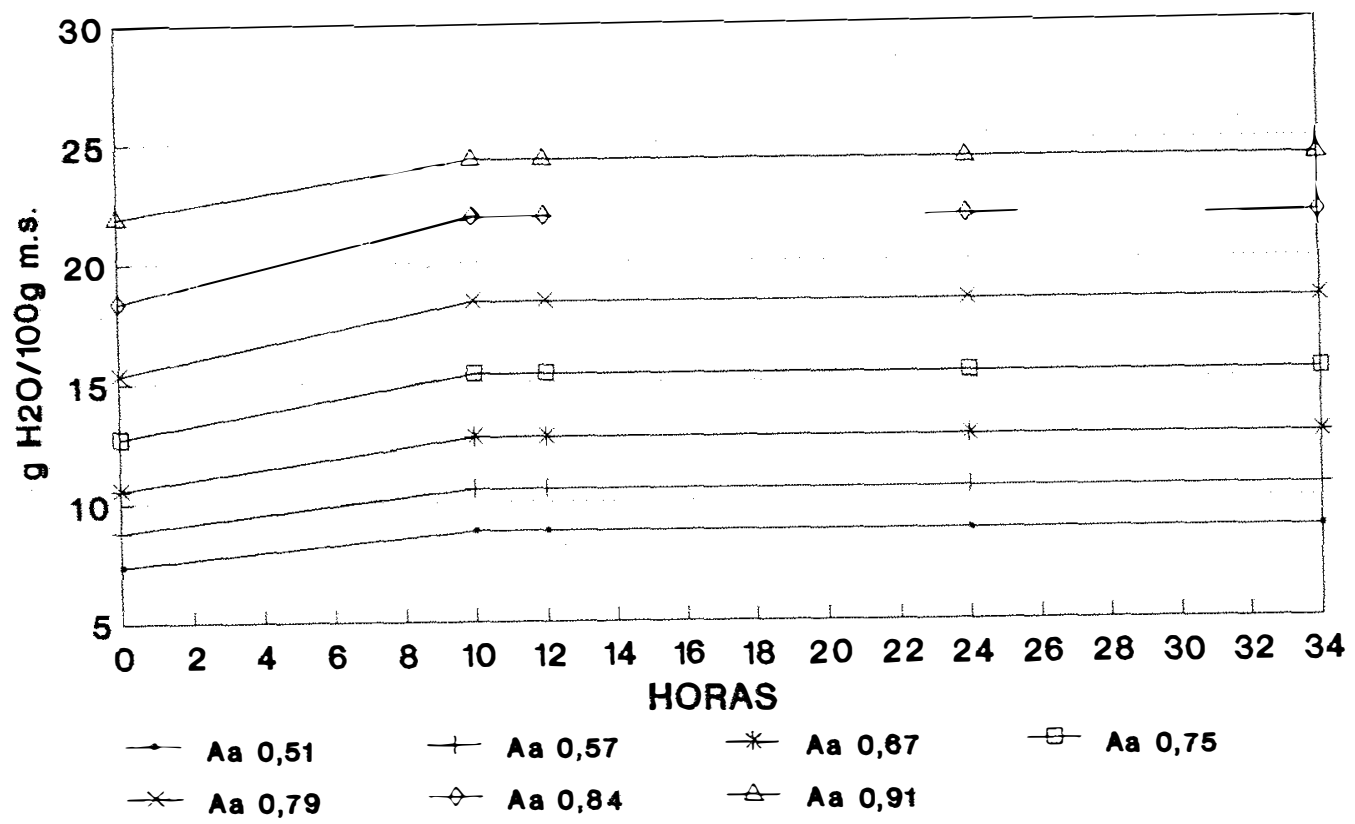

Figura 18. Tempo necessário para equilíbrio. Farinha Integral de soja Céu Azul $30^{\circ} \mathrm{C}$ reciclada.

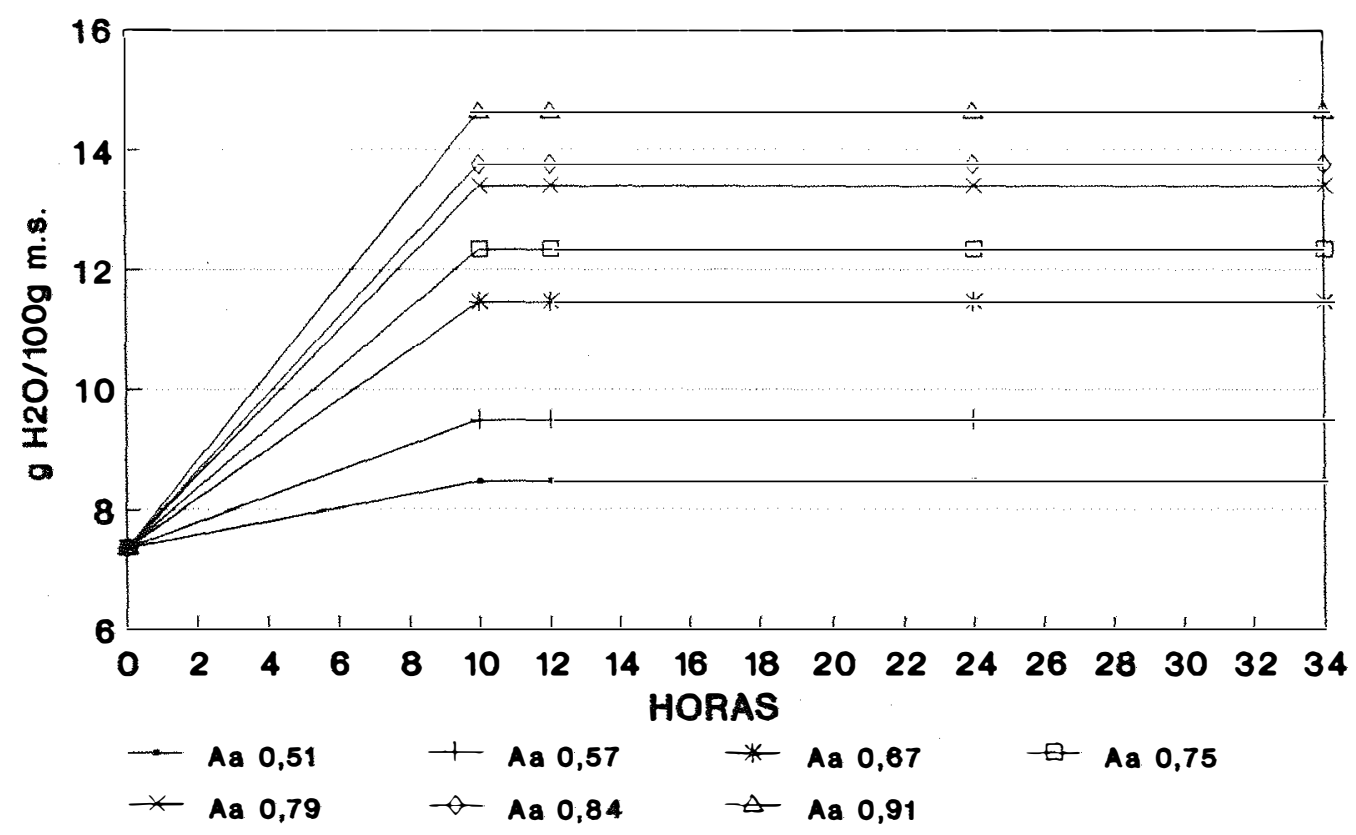

Figura 19. Tempo necessário para equilibrio. Farinha Integral de soja Céu Azul $30^{\circ} \mathrm{C}$ nāo reciclada. 


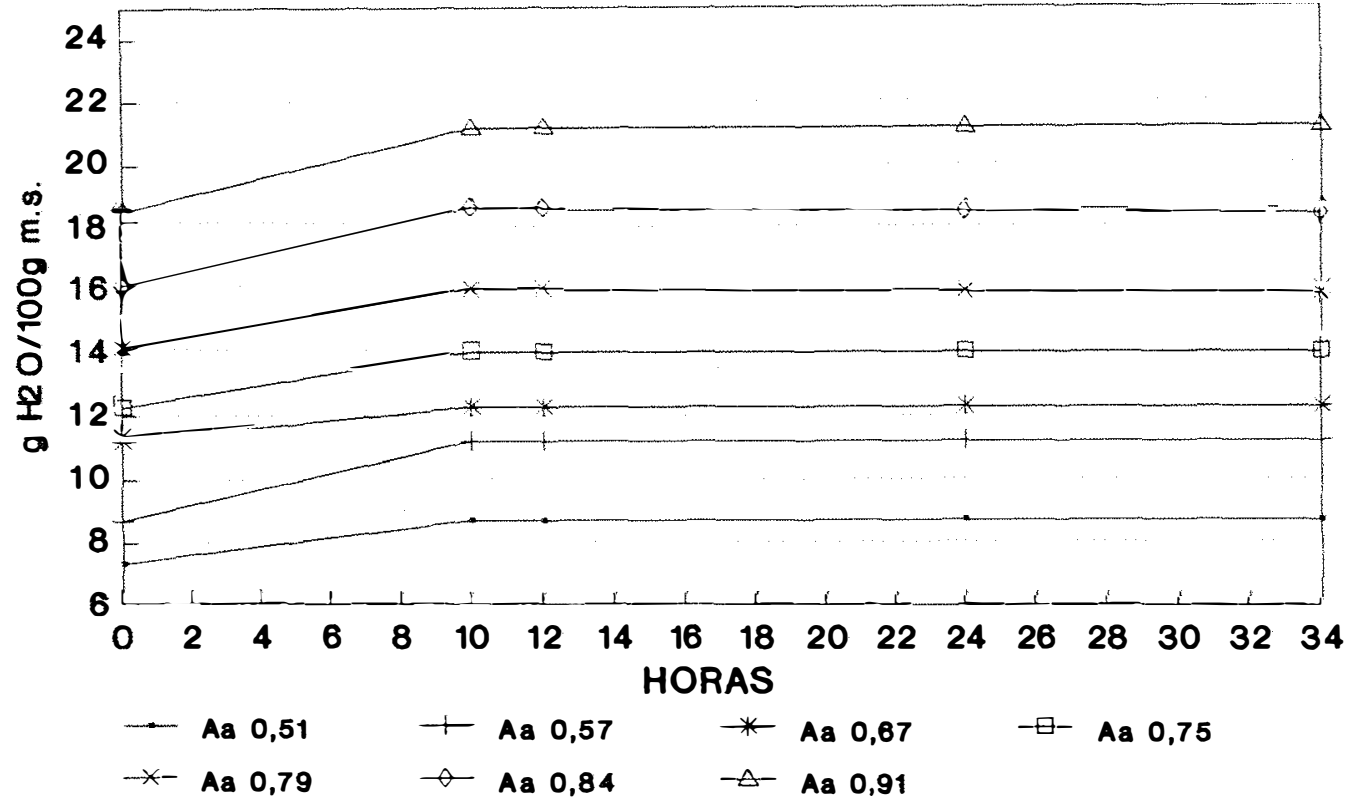

Figura 20. Tempo necessário para equilibrio. Farinha Integral de soja Céu Azul $35^{\circ} \mathrm{C}$ reciclada.

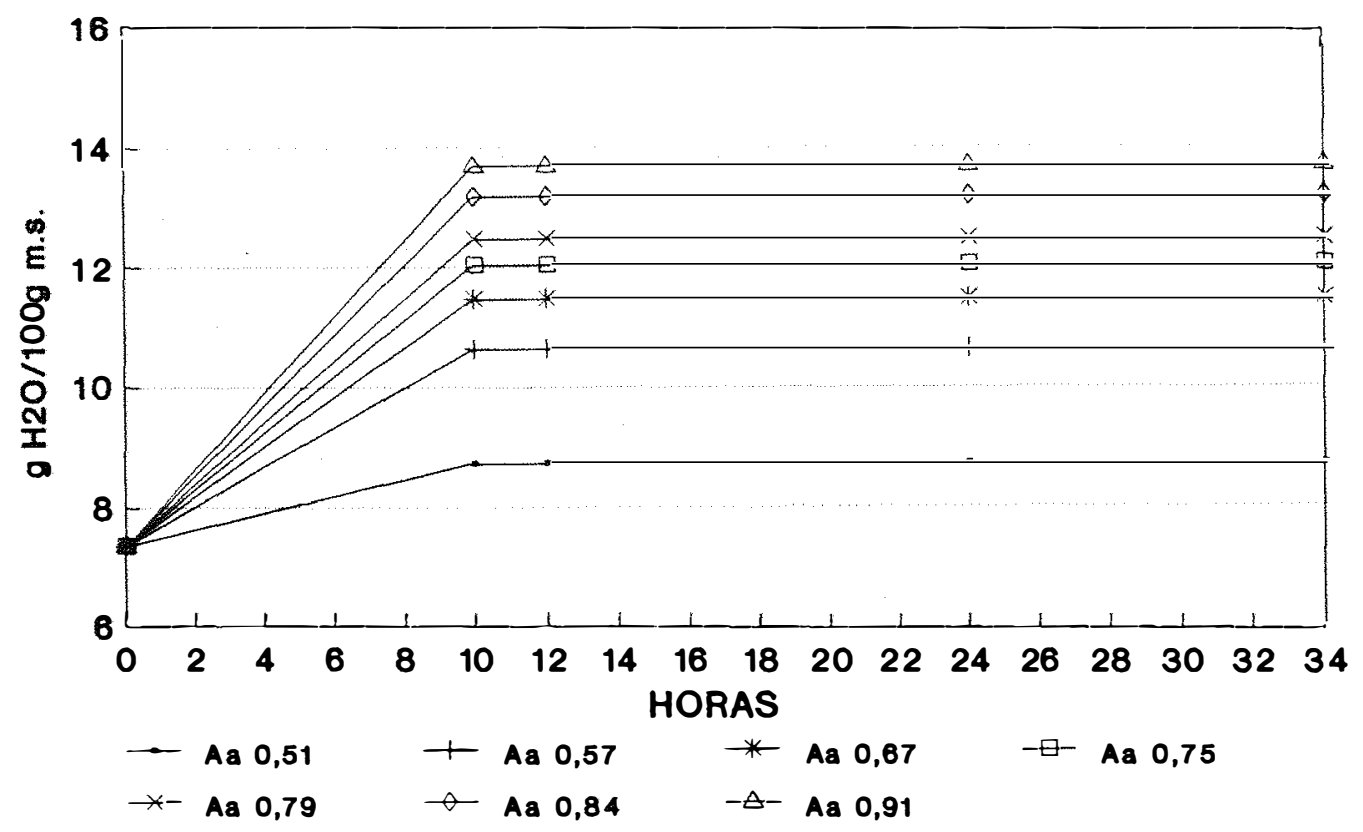

Figura 21. Tempo necessário para equilibrio. Farinha Integral de soja Céu Azul $35^{\circ} \mathrm{C}$ não reciclada. 


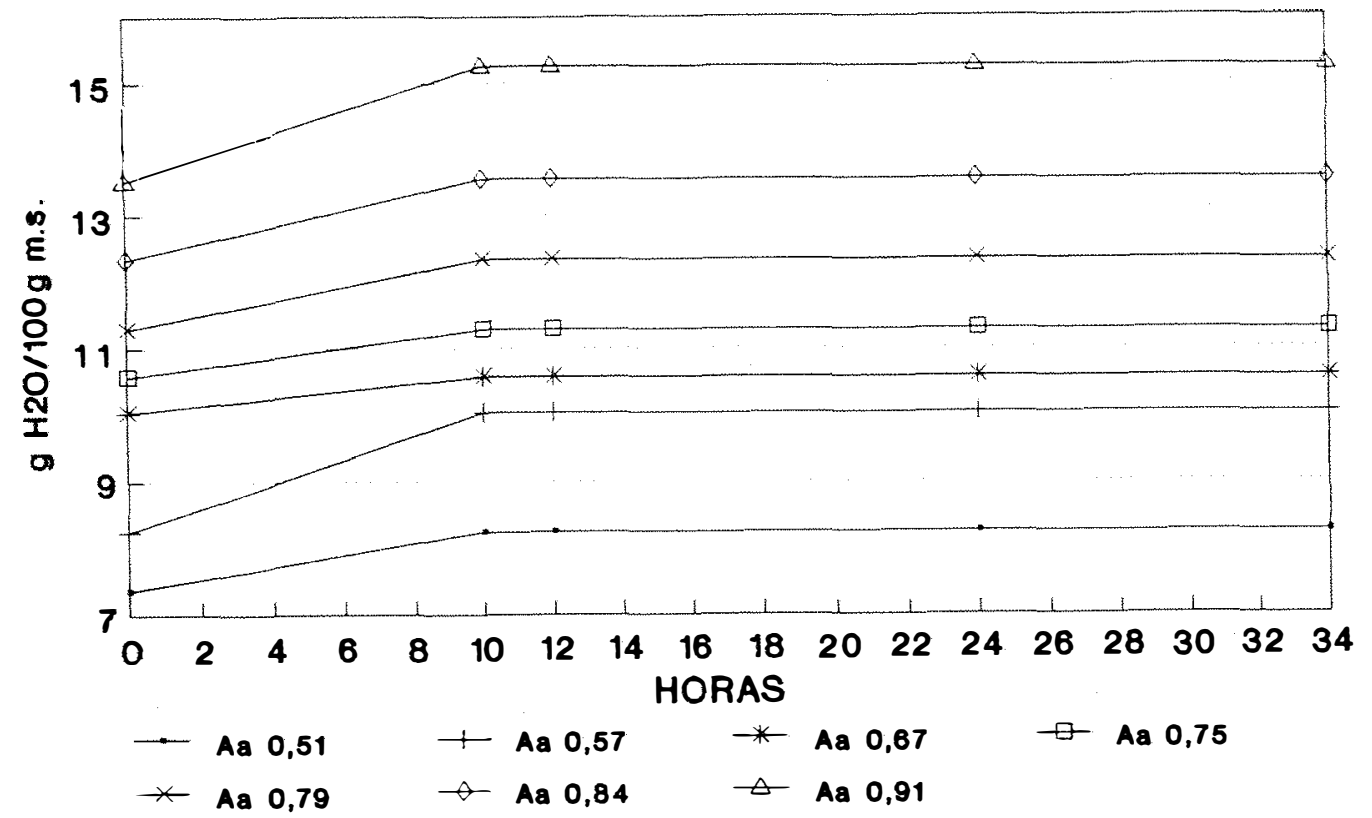

Figura 22. Tempo necessário para equilibrio. Farinha Integral de soja Céu Azul $40^{\circ} \mathrm{C}$ reciclada.

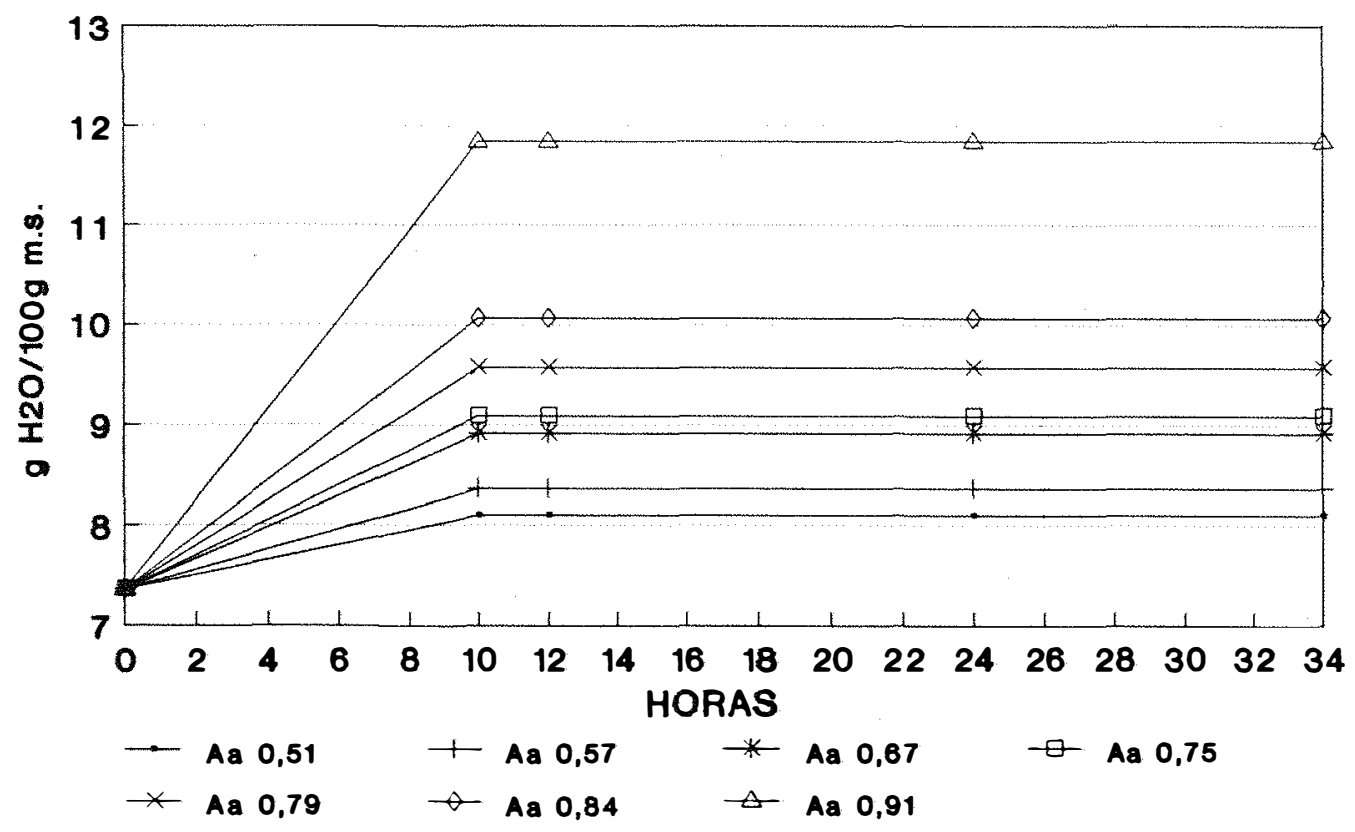

Figura 23. Tempo necessário para equilibrio. Farinha Integral de soja Céu Azul $40^{\circ} \mathrm{C}$ não reciclada. 


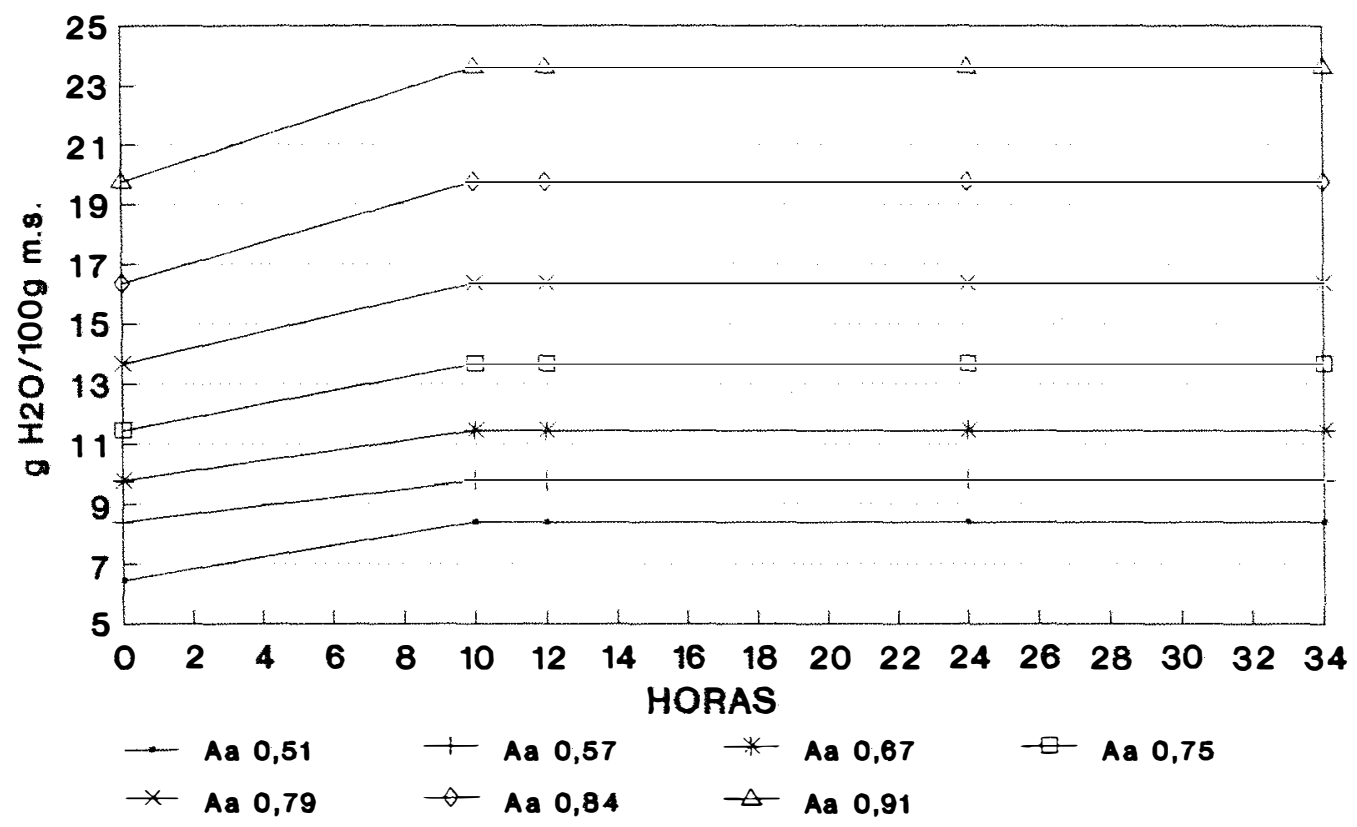

Figura 24. Tempo necessário para equilíbrio. Farinha de soja sem casca Céu Azul $30^{\circ} \mathrm{C}$ reciclada.

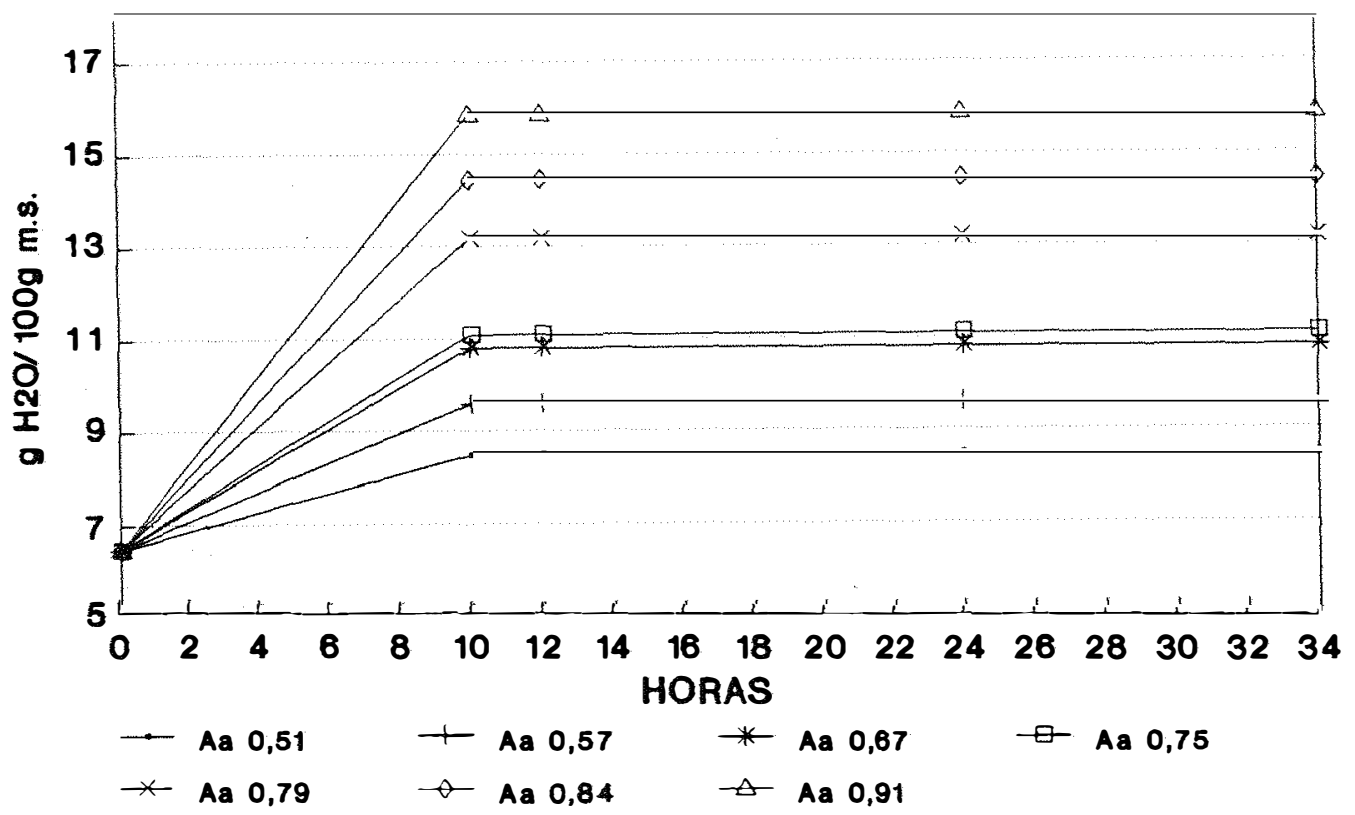

Figura 25. Tempo necessário para equilibrio. Farinha de soja sem casca Céu Azul $30^{\circ} \mathrm{C}$ não reciclada. 


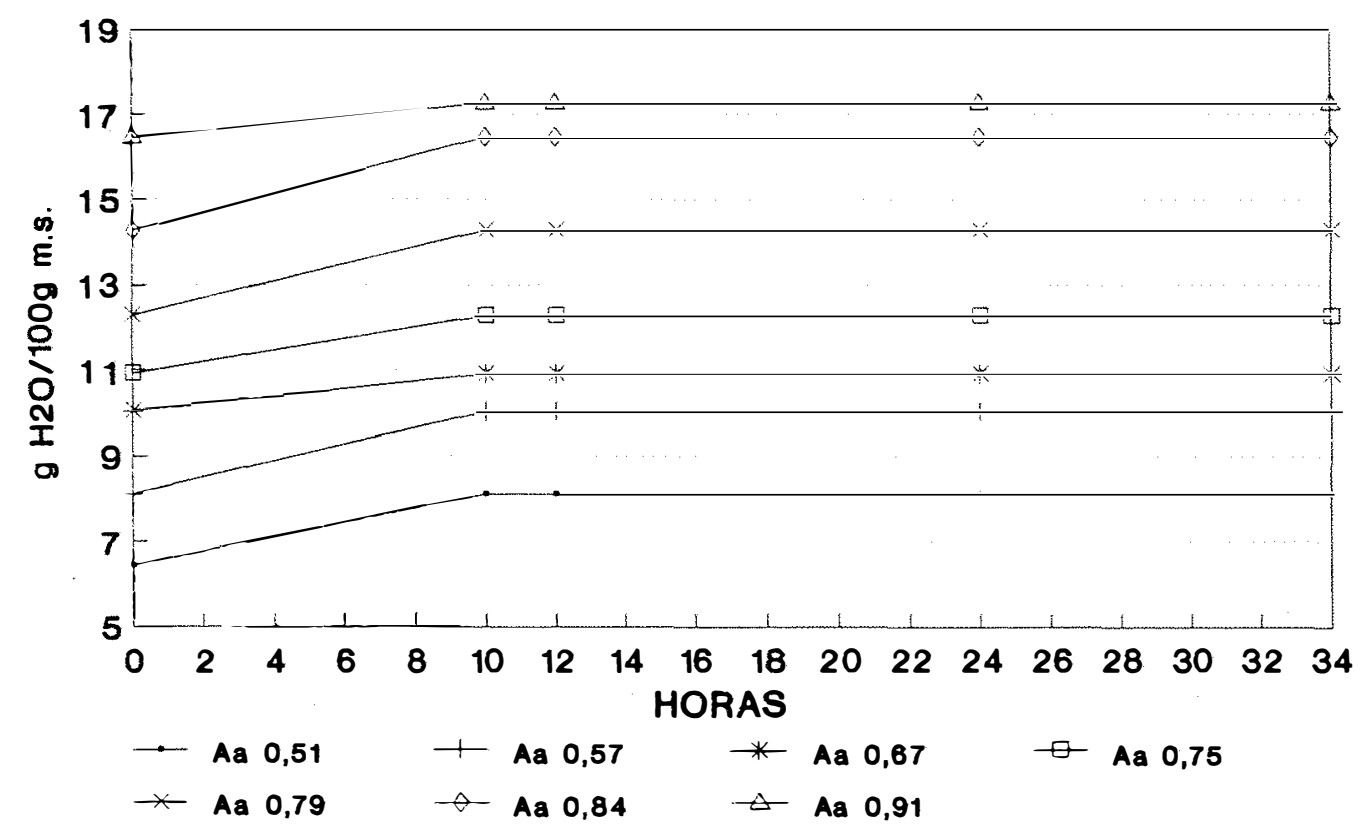

Figura 26. Tempo necessário para equilíbrio. Farinha de soja sem casca Céu Azul $35^{\circ} \mathrm{C}$ reciclada.

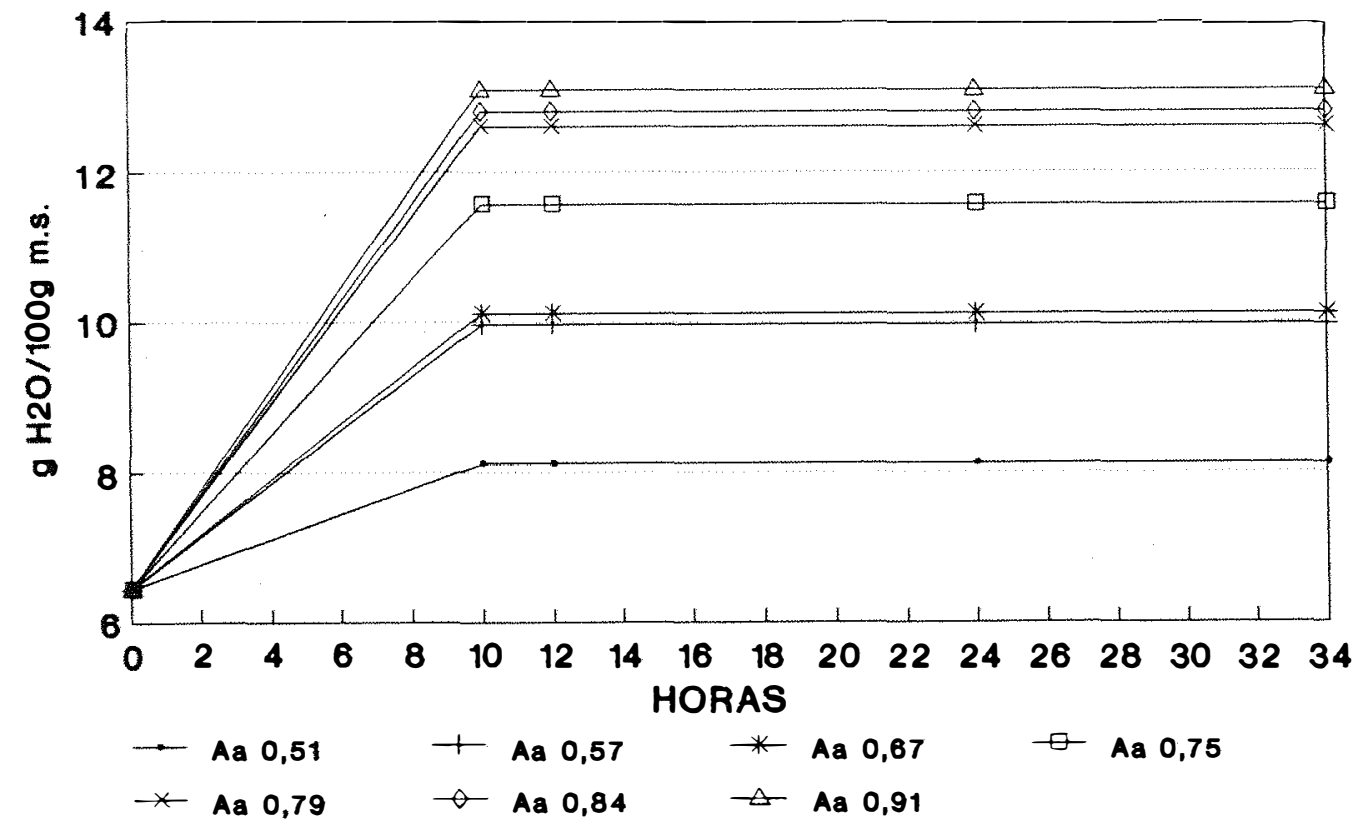

Figura 27. Tempo necessário para equilíbrio. Farinha de soja sem casca Céu Azul $35^{\circ} \mathrm{C}$ não reciclada. 


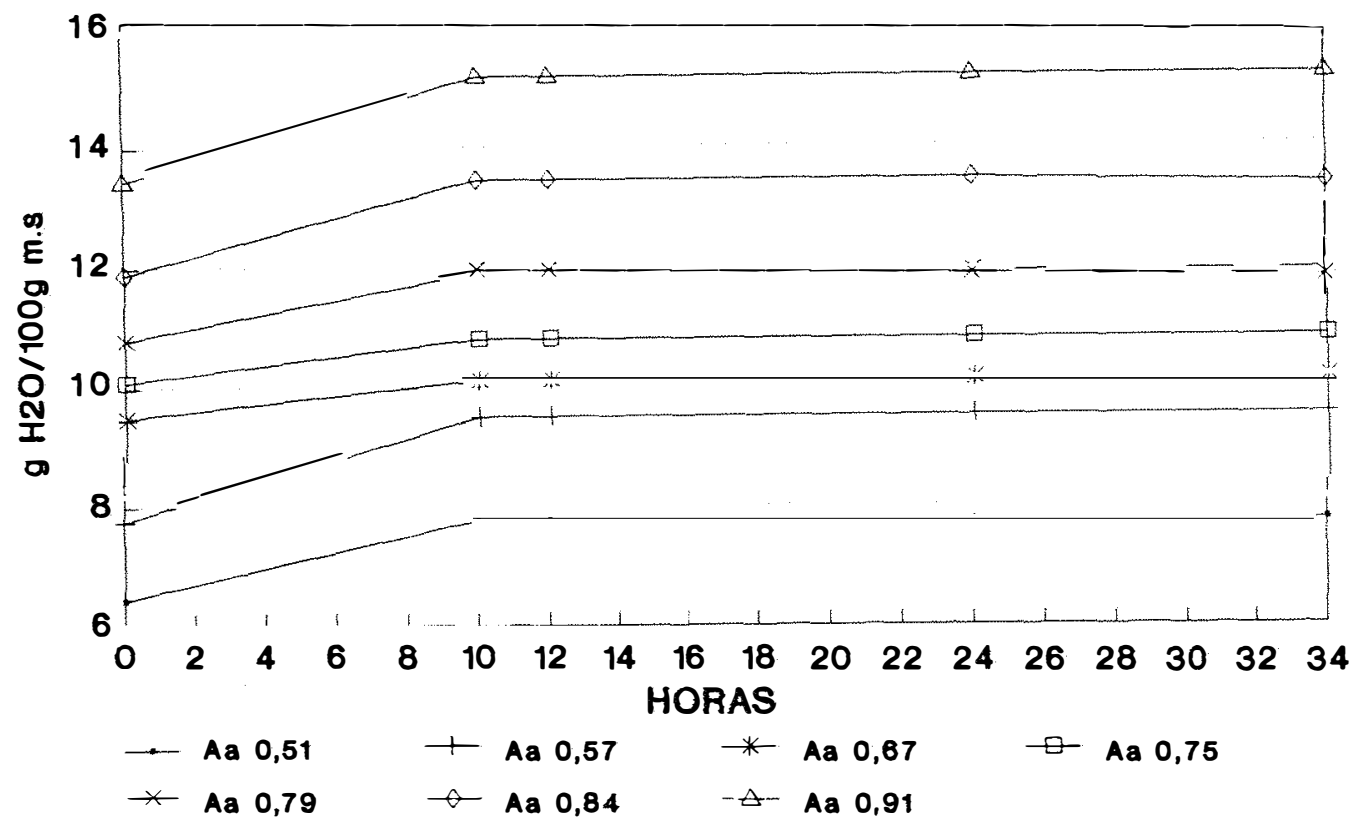

Figura 28. Tempo necessário para equilibrio. Farinha de soja sem casca Céu Azul $40^{\circ} \mathrm{C}$ reciclada.

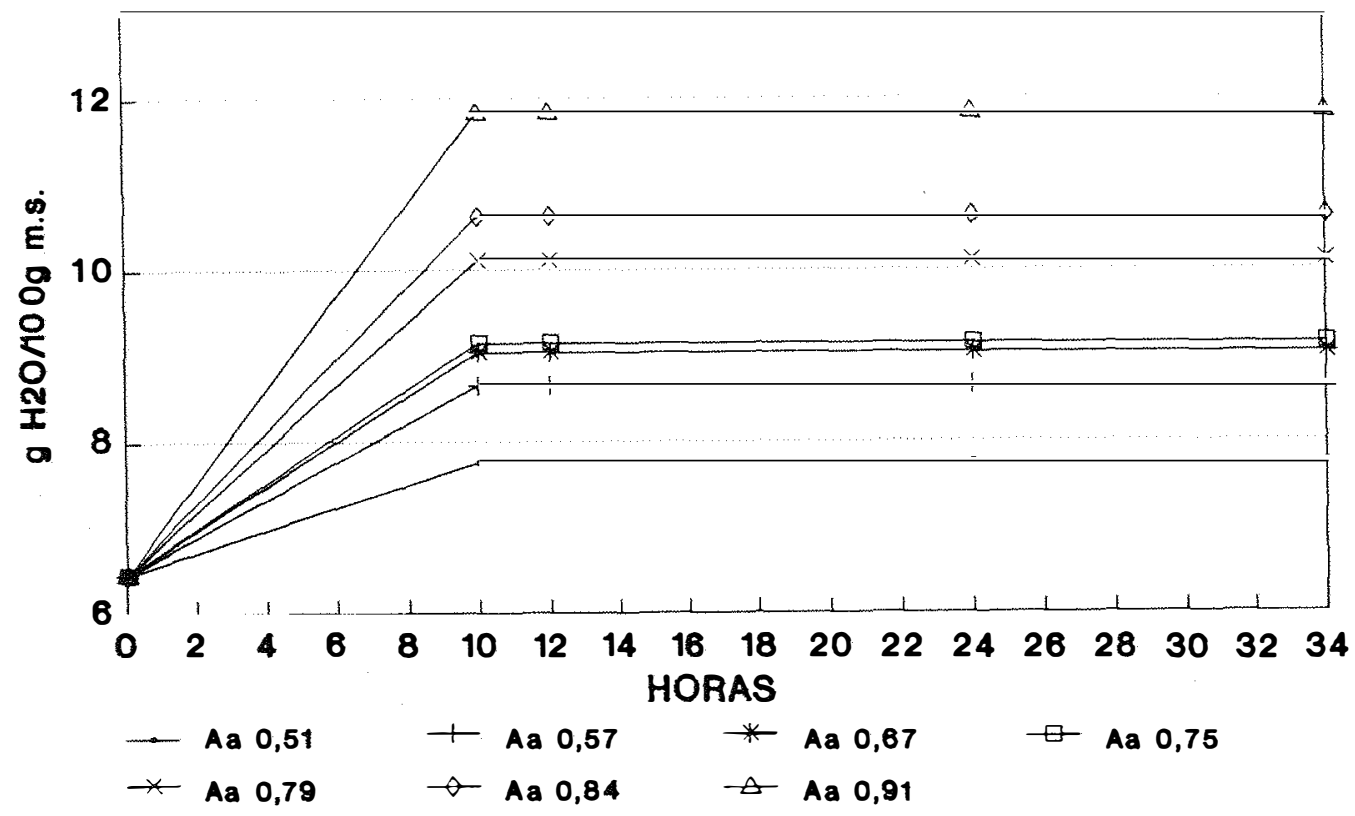

Figura 29. Tempo necessário para equilíbrio. Farinha de soja sem casca Céu Azul $40^{\circ} \mathrm{C}$ não reciclada. 


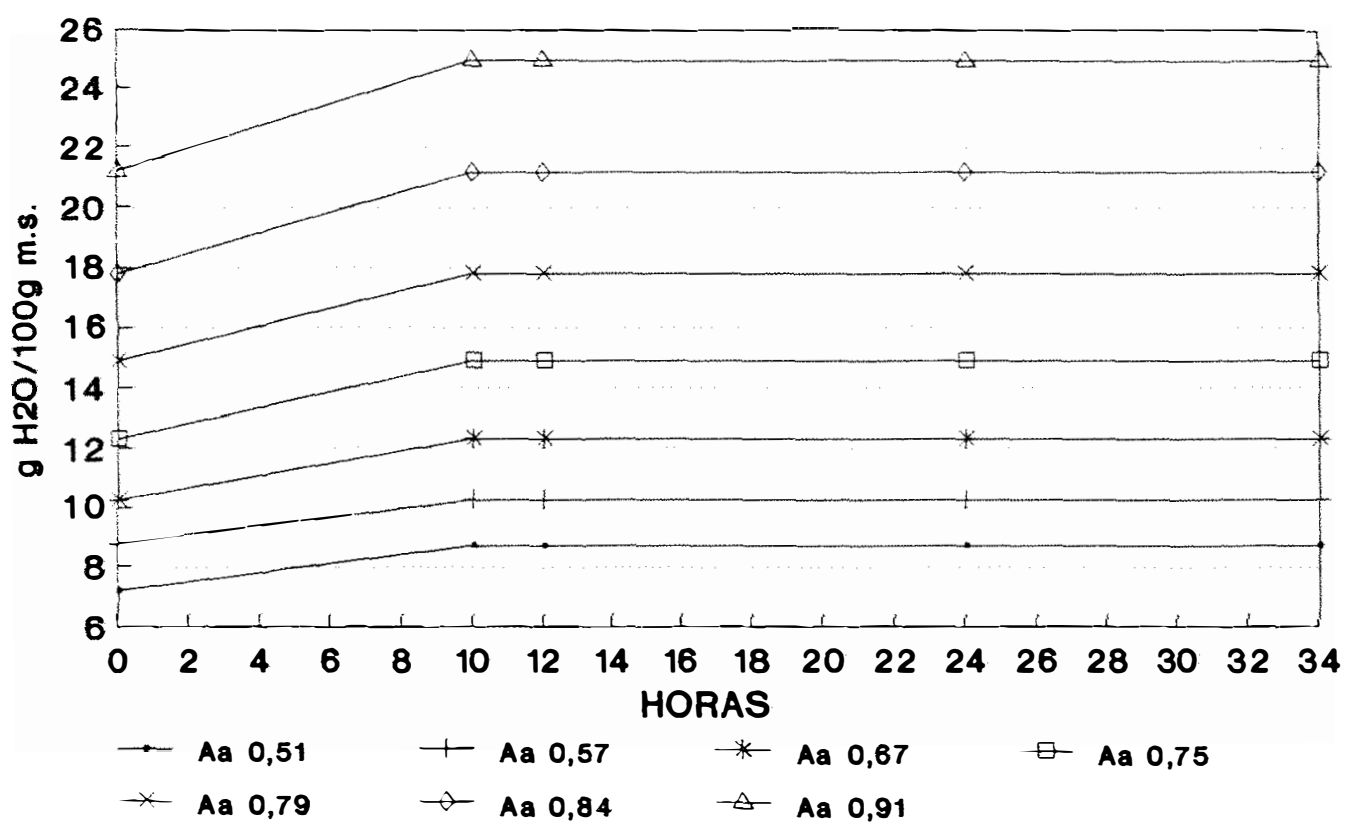

Figura 30. Tempo necessário para equilibrio. Farinha Integral de soja IAC-08 $30^{\circ} \mathrm{C}$ reciclada

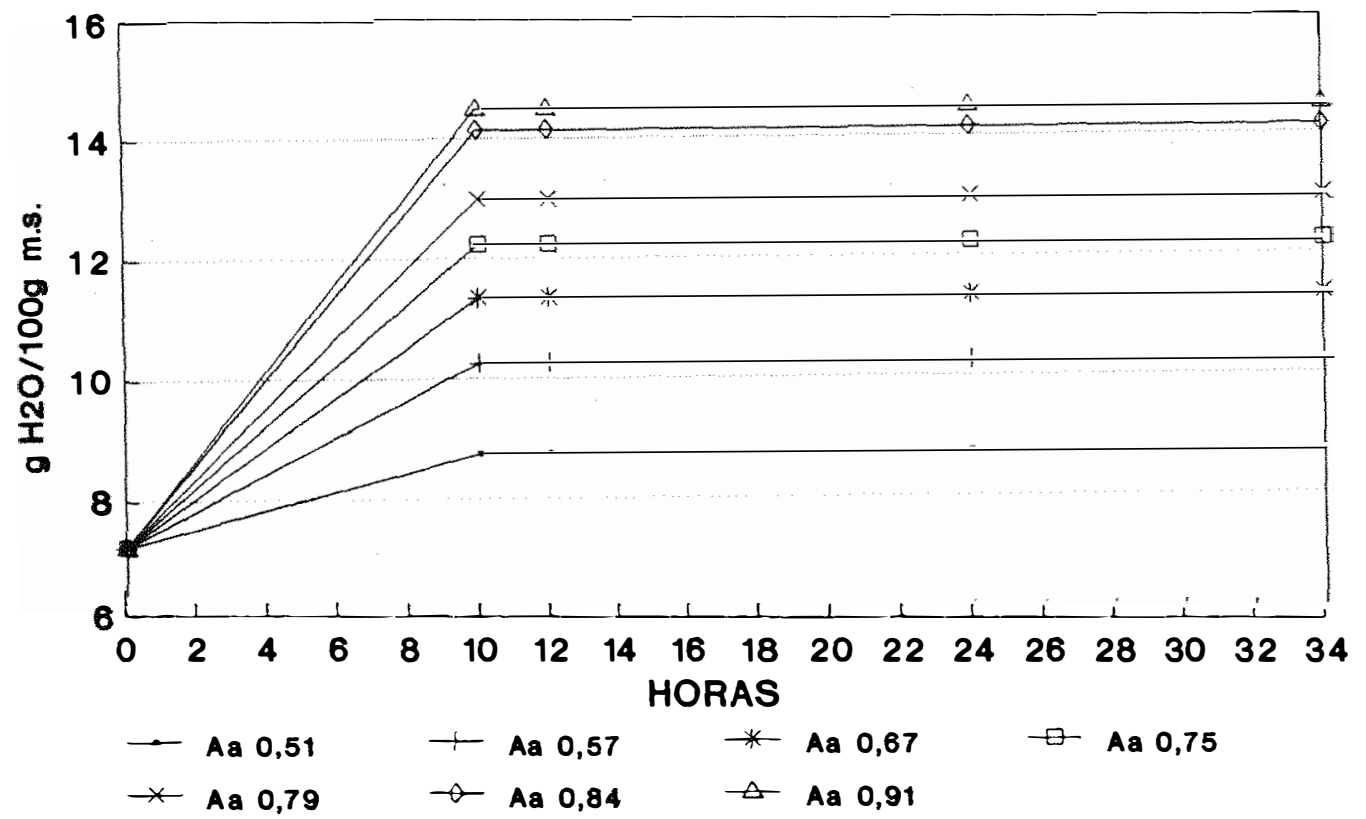

Figura 31. Tempo necessário para equilßorio. Farinha Integral de soja IAC-08 $30^{\circ} \mathrm{C}$ não reciclada 


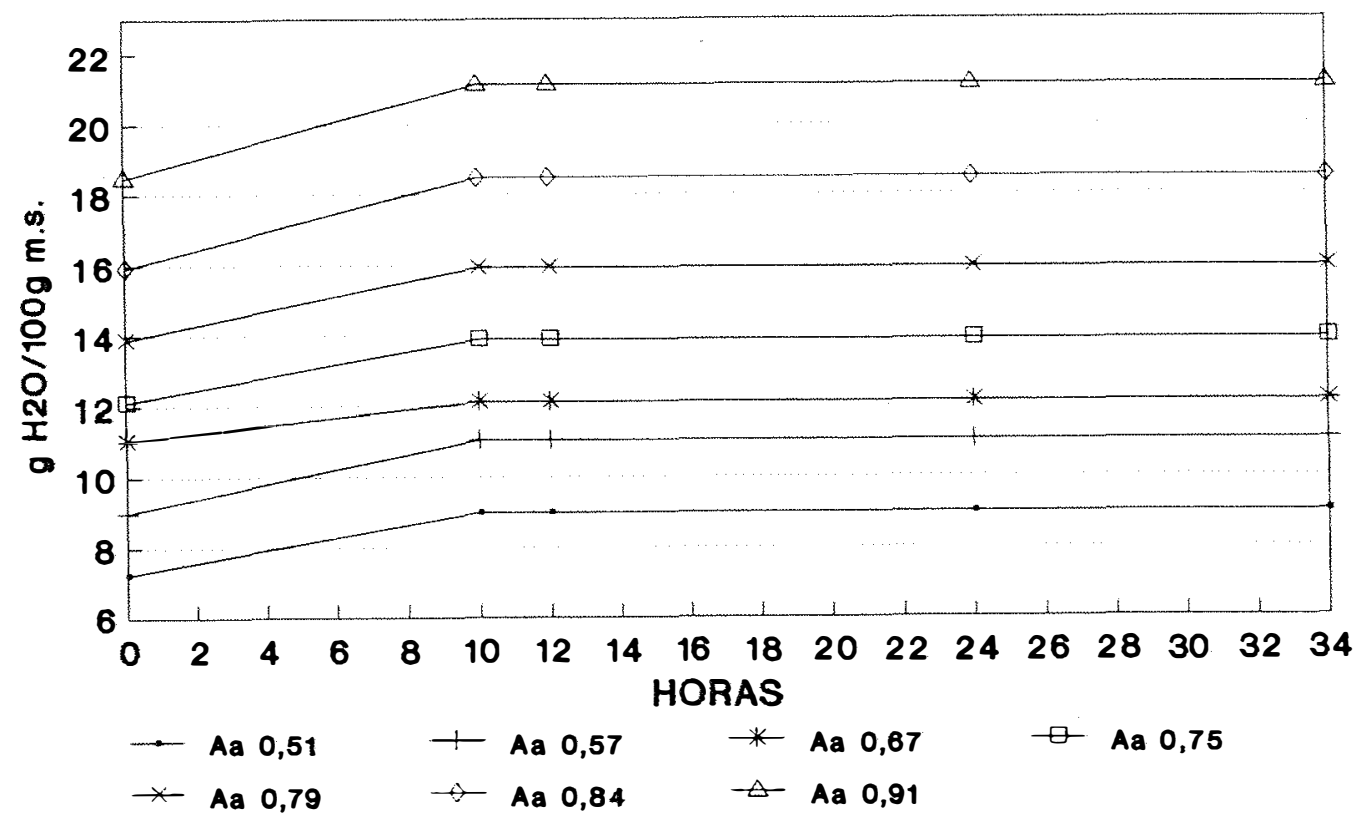

Figura 32. Tempo necessário para equilibrio. Farinha Integral de soja IAC-08 $35^{\circ} \mathrm{C}$ reciclada

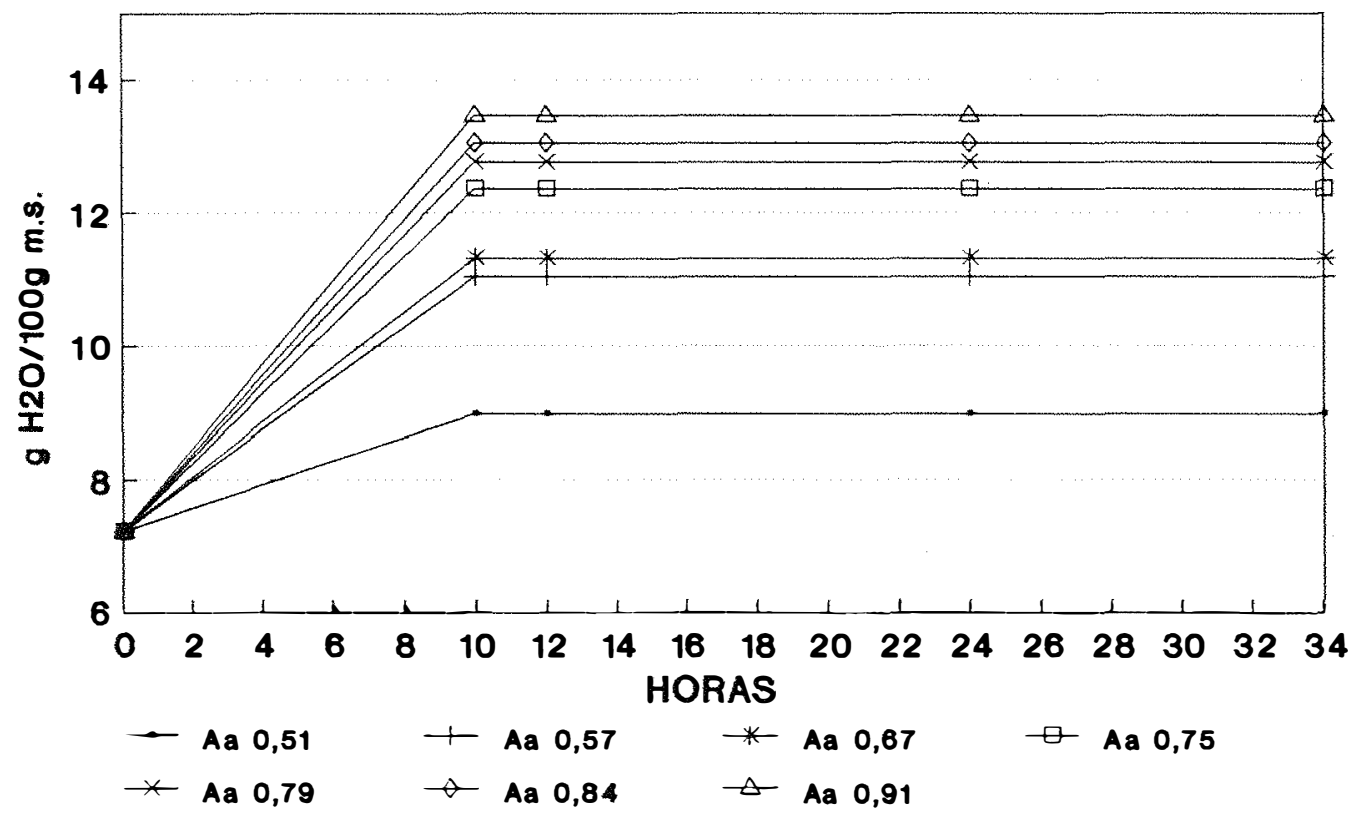

Figura 33. Tempo necessário para equilibrio. Farinha Integral de soja IAC-08 $35^{\circ} \mathrm{C}$ não reciclada 


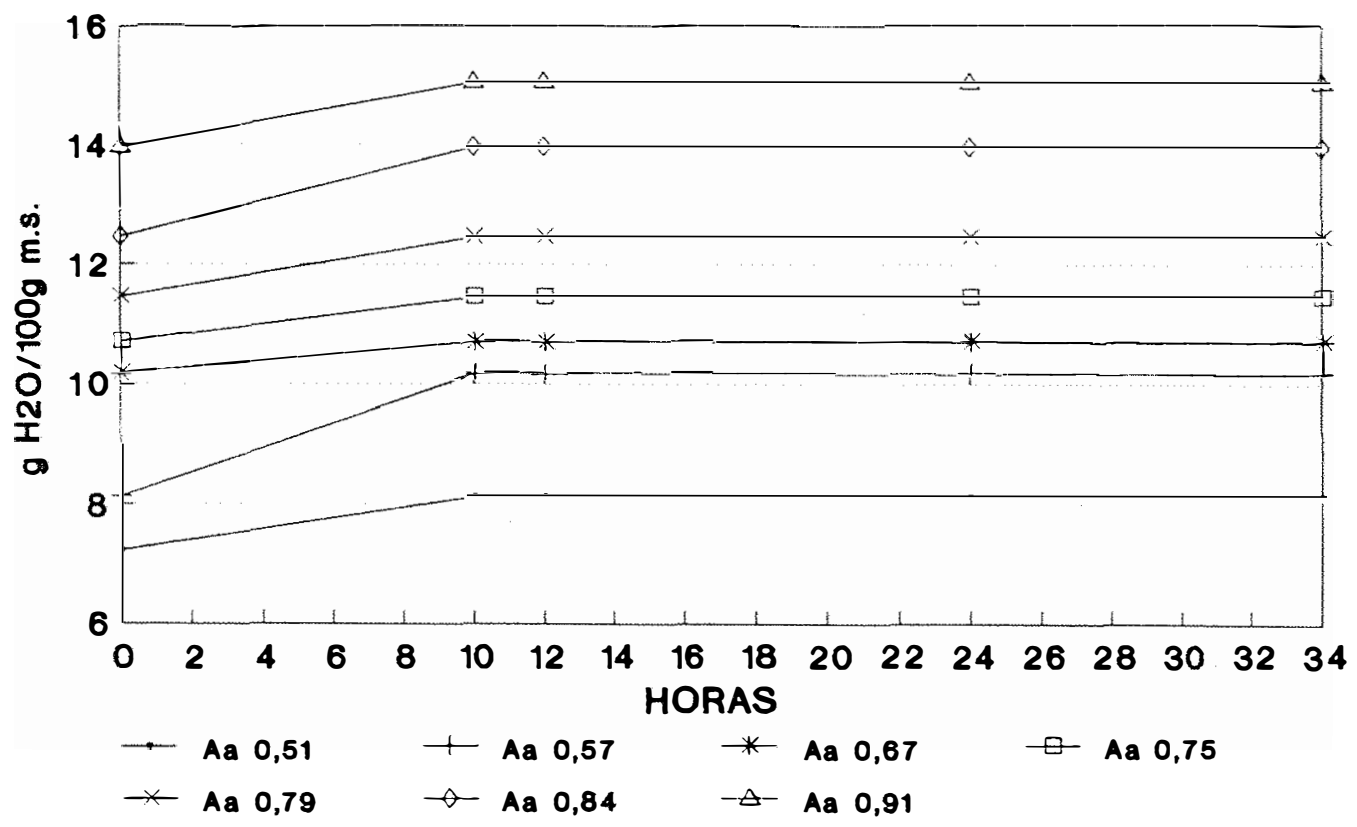

Figura 34. Tempo necessário para equilibrio. Farinha Integral de soja IAC-08 $40^{\circ} \mathrm{C}$ reciclada

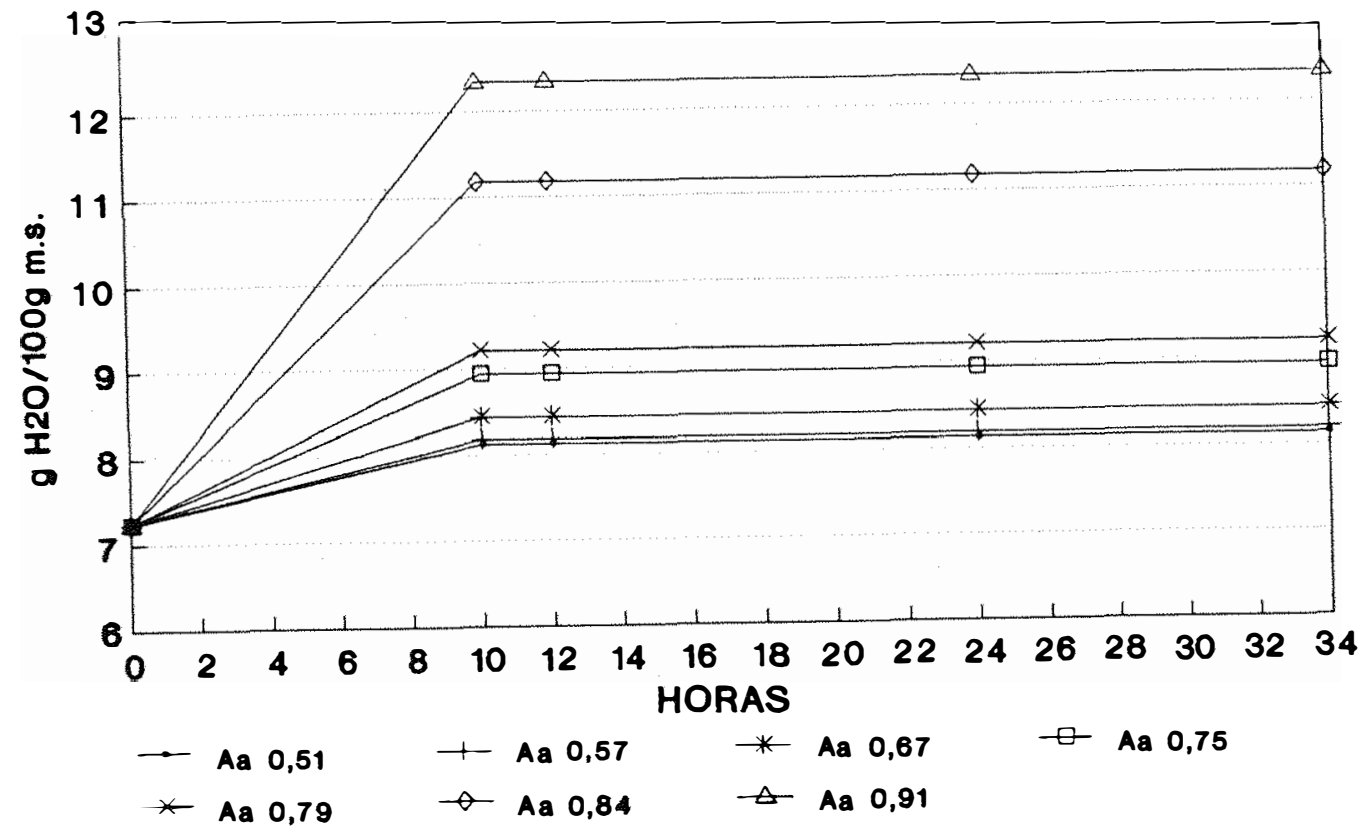

Figura 35. Tempo necessário para equilibrio. Farinha Integral de soja IAC-08 $40^{\circ} \mathrm{C}$ não reciclada 


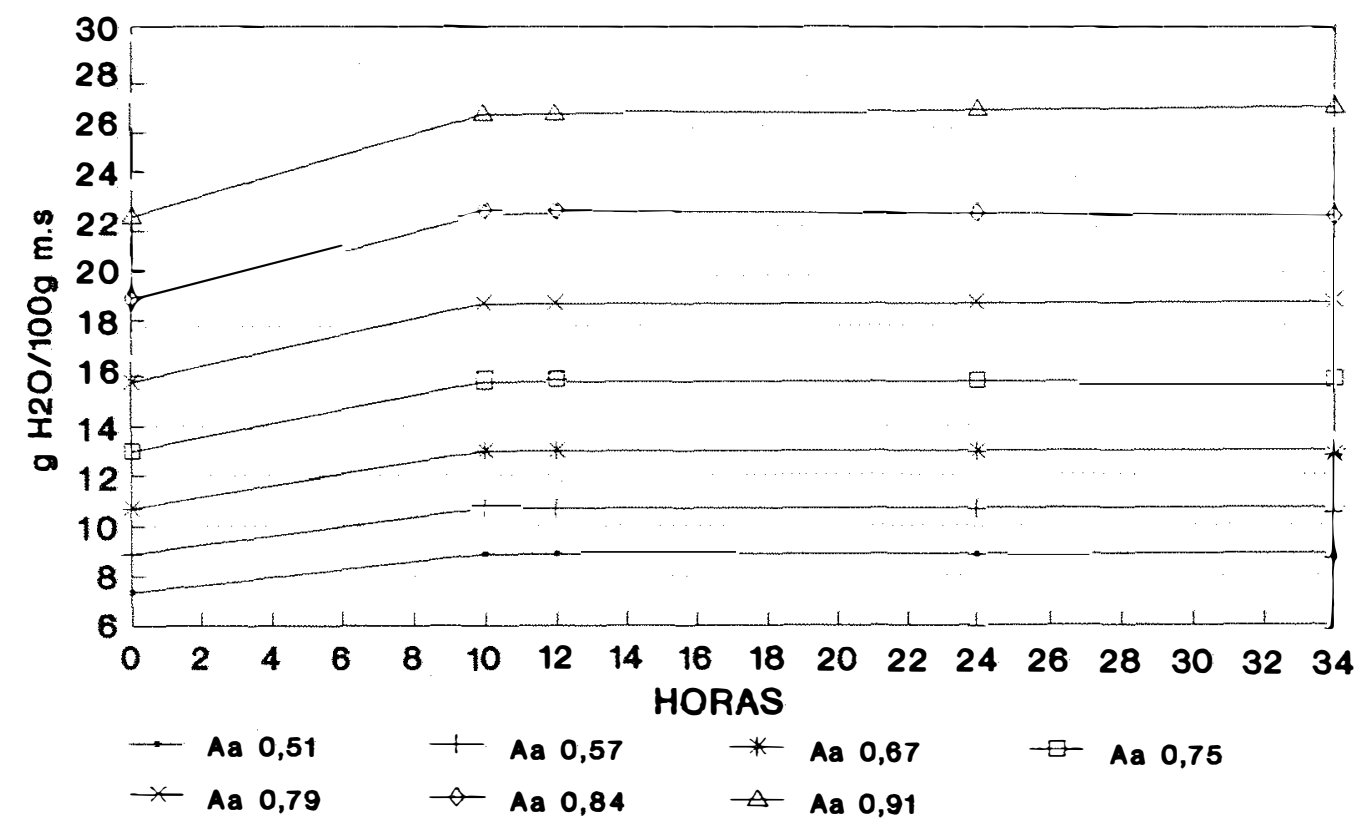

Figura 36. Tempo necessário para equilibrio. Farinha de soja sem casca IAC-08 $30^{\circ} \mathrm{C}$ reciclada.

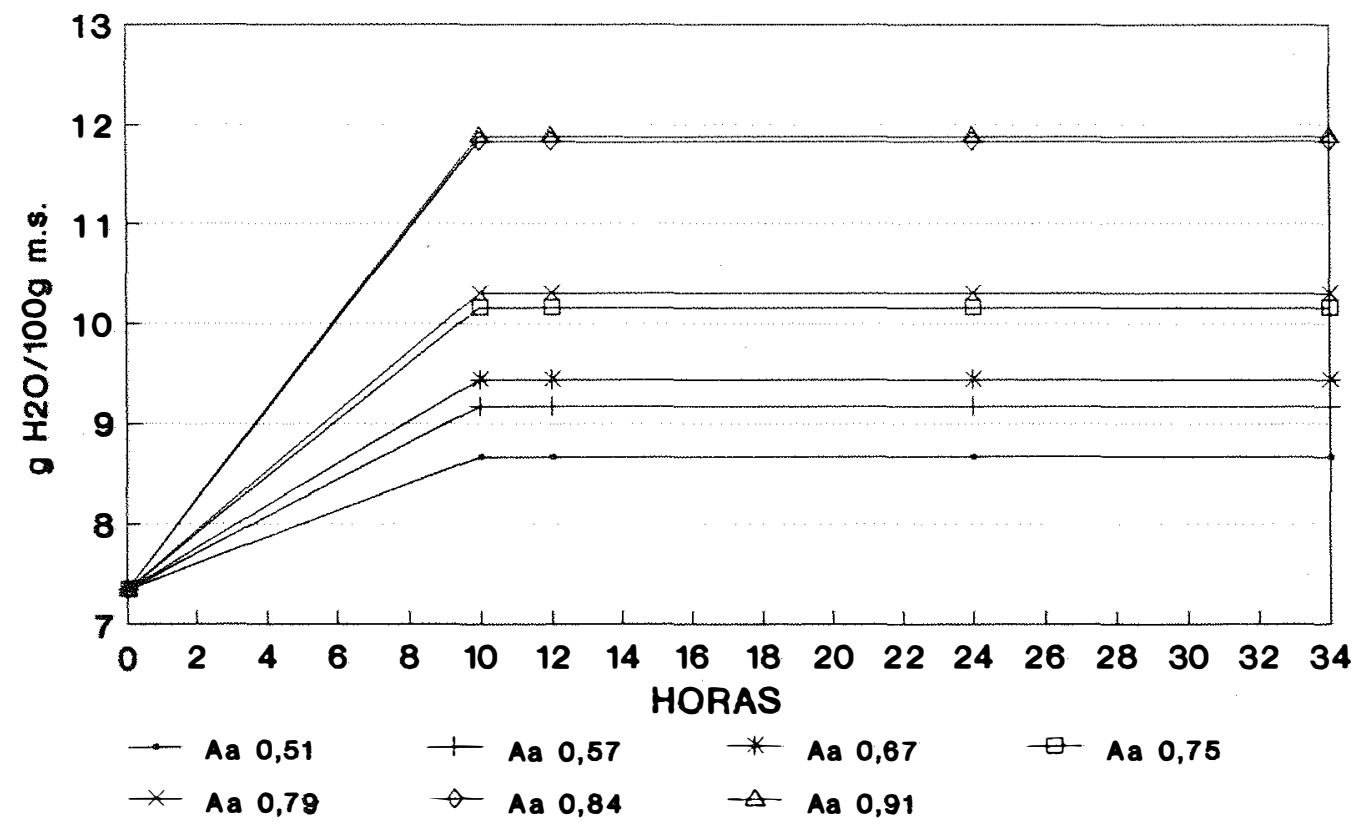

Figura 37. Tempo necessário para equilibrio. Farinha de soja sem casca IAC-08 $30^{\circ} \mathrm{C}$ não reciclada. 


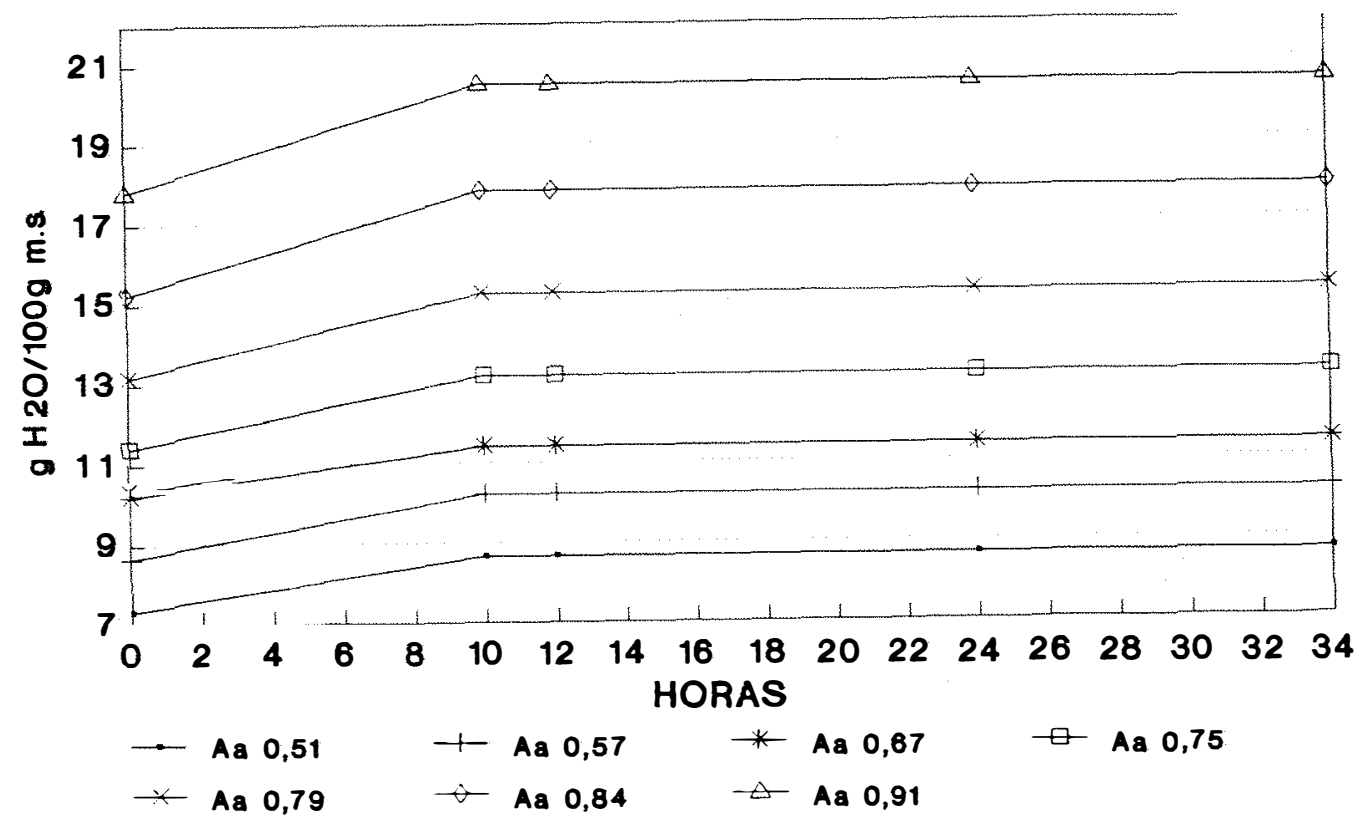

Figura 38. Tempo necessário para equilibrio. Farinha de soja sem casca IAC-08 $35^{\circ} \mathrm{C}$ reciclada.

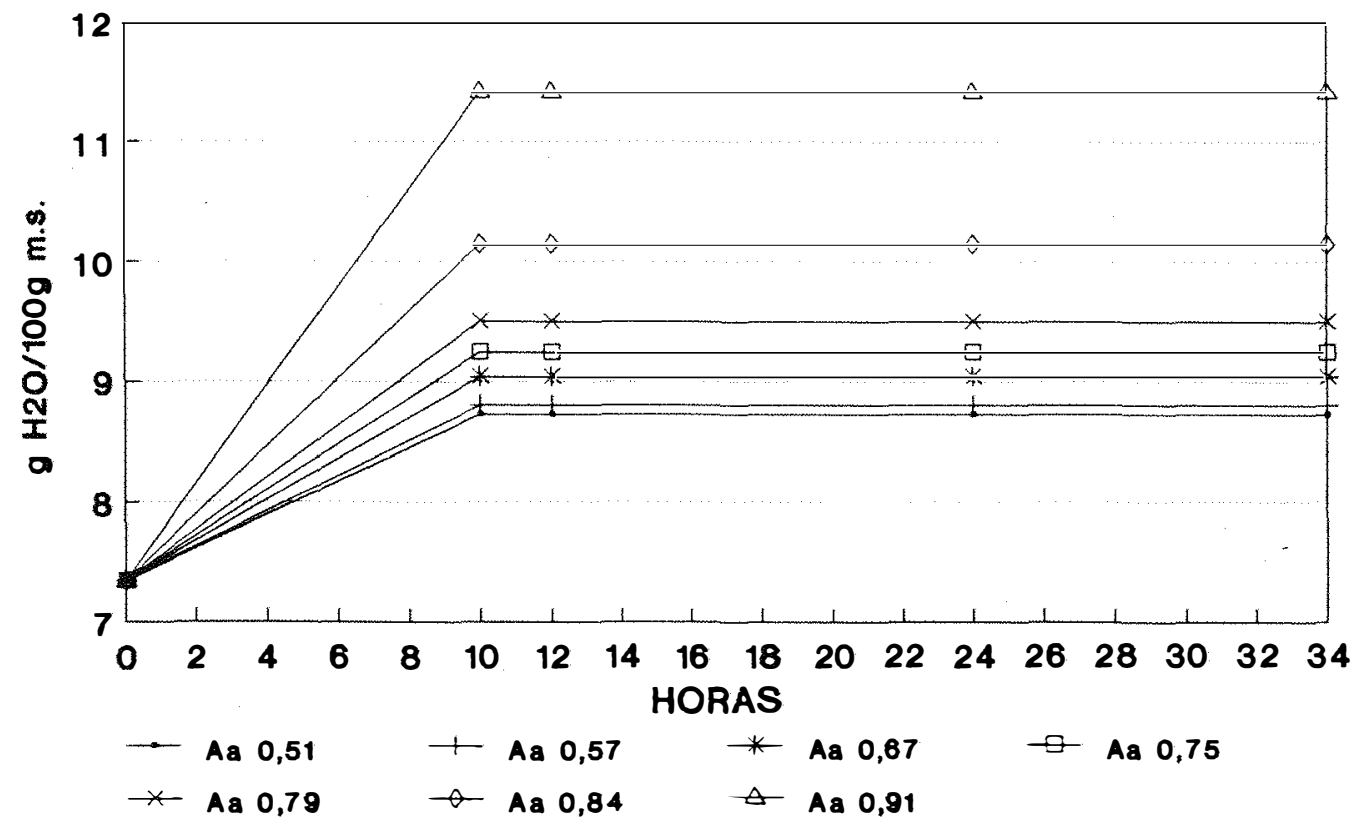

Figura 39. Tempo necessário para equilibrio. Farinha de soja sem casca IAC-08 $35^{\circ} \mathrm{C}$ não reciclada. 


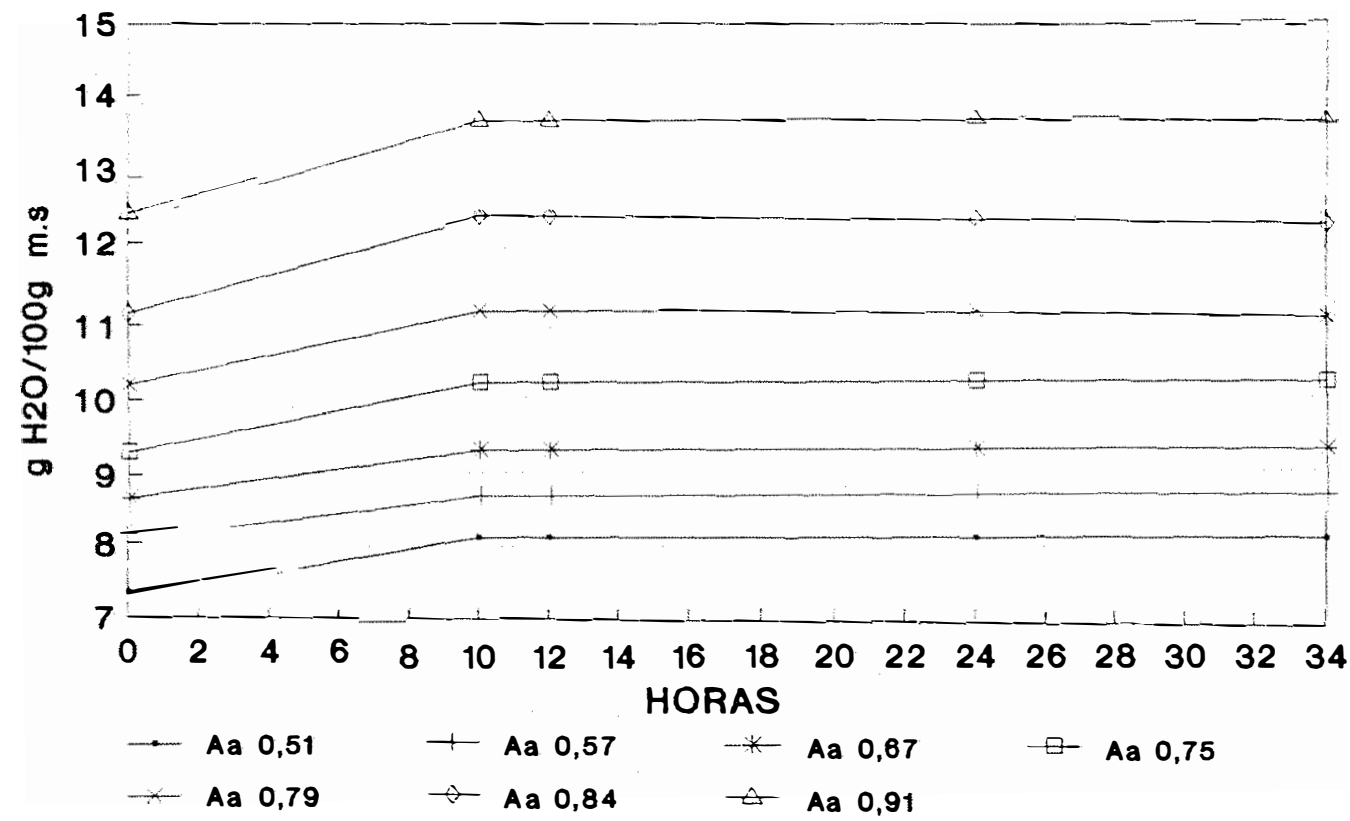

Figura 40. Tempo necessário para equilibrio. Farinha de soja sem casca IAC-08 $40^{\circ} \mathrm{C}$ reciclada.

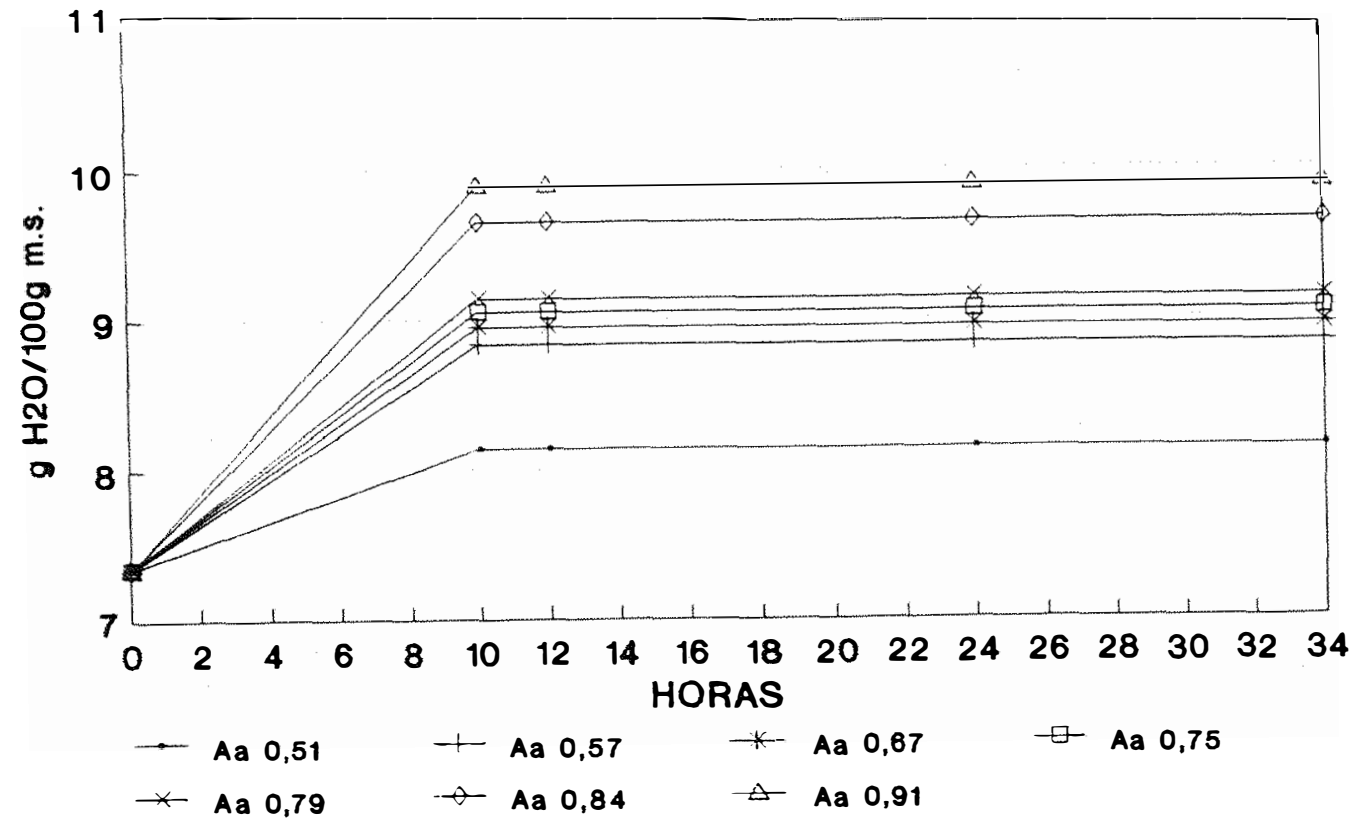

Figura 41. Tempo necessário para equilibrio. Farinha de soja sem casca IAC-08 $40^{\circ} \mathrm{C}$ não reciclada. 
Observa-se que, para todas as amostras, recicladas e não recicladas, em todas as temperaturas, o equilibrio já se estabelecia na $10^{a}$ hora, com única exceção para a farinha de mandioca onde o equilibrio se deu à $11^{\mathrm{a}}$ hora.

Para o modelo de equipamento construído, a torre de umidificação propicia um estabelecimento rápido de uma umidade relativa desejada na corrente do ar que recircula na câmara, levando a um tempo muito curto para atingir o equilibrio das amostras com a umidade relativa ambiental. A eficiência e a economia de tempo obtidos são, sensivelmente, superiores às conseguidas em equipamento com outra modalidade de recirculação e, com materiais similares (PRADO FILHO \& SABBAGH, 1993).

Não há termos de comparação para os tempos exigidos para equilibrio pelo método estático em dessecadores, como por exemplo, mais de 50 dias para grãos (PARK, 1992) ou 4 a 10 dias para alginato de sódio (KIMURA, 1992).

A introdução no equipamento de uma pequena turbina de 8 pás com acionamento interno, é uma solução muito econômica e eficiente, propiciando, com os materiais estudados, um ganho de tempo e mão-de-obra bastante significativos. Além disso, é possível trabalhar em Aa elevadas, com as amostras não recicladas, sem que houvesse proliferação microbiana notável, sem o uso de desinfectantes.

As Figuras 42 a 53, mostram as isotermas de adsorção das farinhas de mandioca Deusa, fubá mimoso Kitano, farinha de soja integral e sem casca das variedades Céu Azul e IAC-08, recicladas e não recicladas, às temperaturas de $30^{\circ} \mathrm{C}$, $35^{\circ} \mathrm{C}$ e $40^{\circ} \mathrm{C}$. Deve ser observada que a adsorção de umidade foi diferente para cada 
farinha, em uma mesma atividade de água, conforme observado por VAN DEN BERG \& BRUIN (1981).

A temperatura exerce efeitos significativos sobre o valor da umidade de equilíbrio, observa-se que, com o aumento da temperatura, os valores da umidade de equilibrio, para as diferentes Aa, sofriam uma diminuição para todas as farinhas utilizadas. Segundo BENEDETTI et al. (1987), um aumento de temperatura, a uma umidade relativa constante tem-se uma diminuição no valor de umidade de equilibrio. A temperatura afeta a mobilidade das moléculas de água e influência as isotermas de adsorção de umidade. Fixado um certo valor de Aa, observa-se que o produto torna-se menos higroscópico com o aumento da temperatura (PITOMBO et al., 1993). 


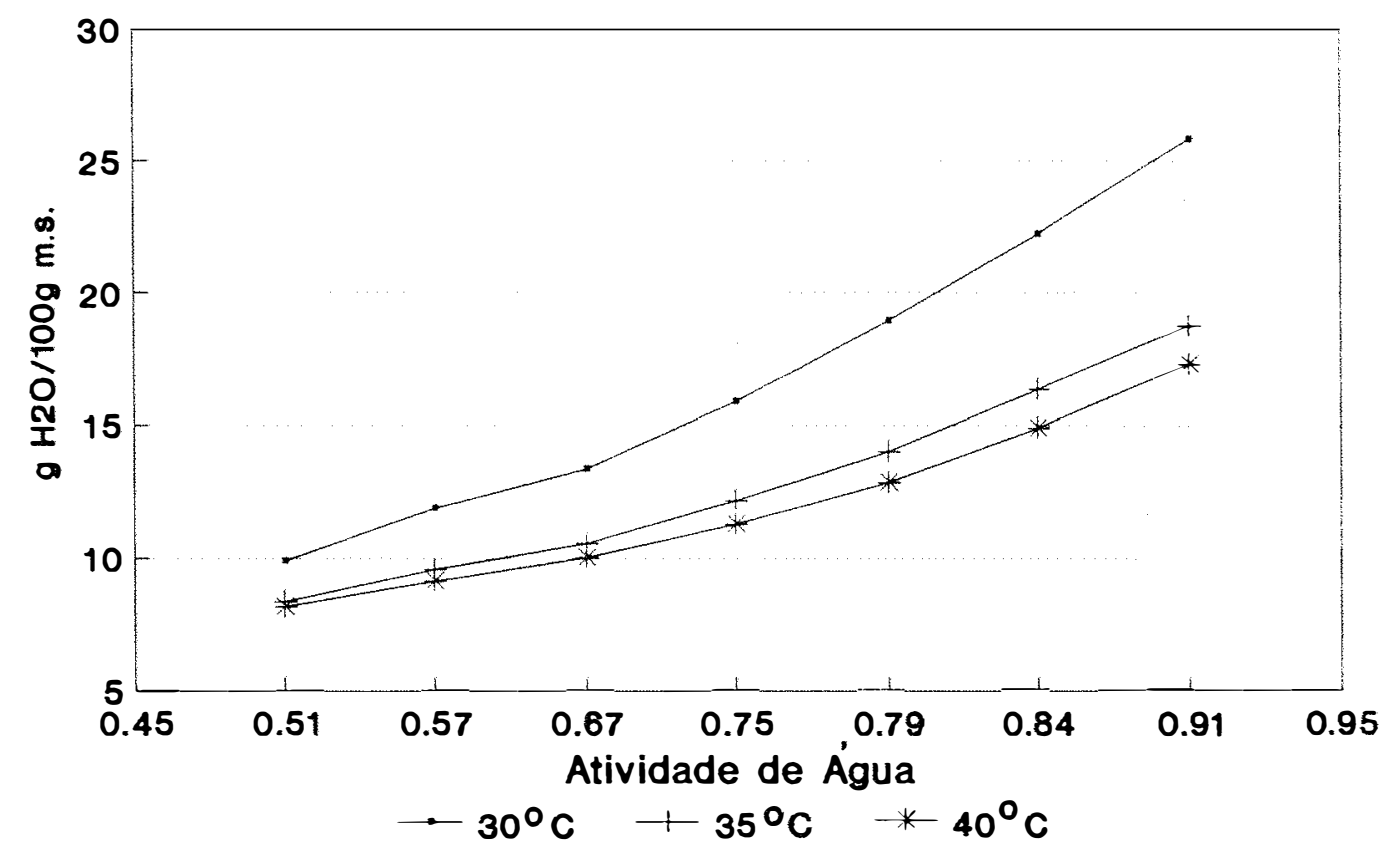

Figura 42. Isotermas parciais de adsorção de fubá Mimoso reciclado a $30^{\circ} \mathrm{C}, 35^{\circ} \mathrm{C}$ e $40^{\circ} \mathrm{C}$.

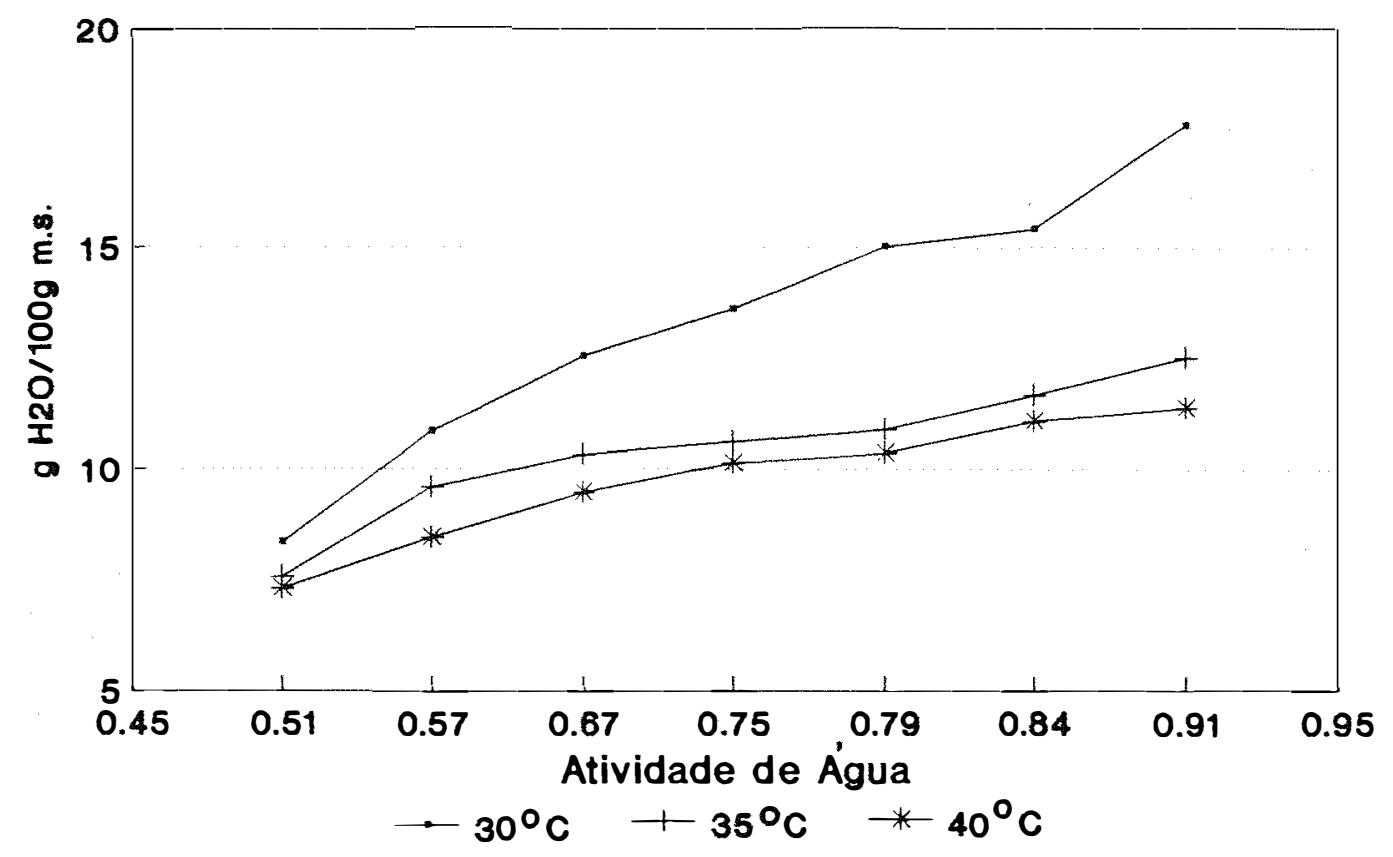

Figura 43. Isotermas parciais de adsorção de fubá Mimoso não reciclado a $30^{\circ} \mathrm{C}, 35^{\circ} \mathrm{C}$ e $40^{\circ} \mathrm{C}$. 


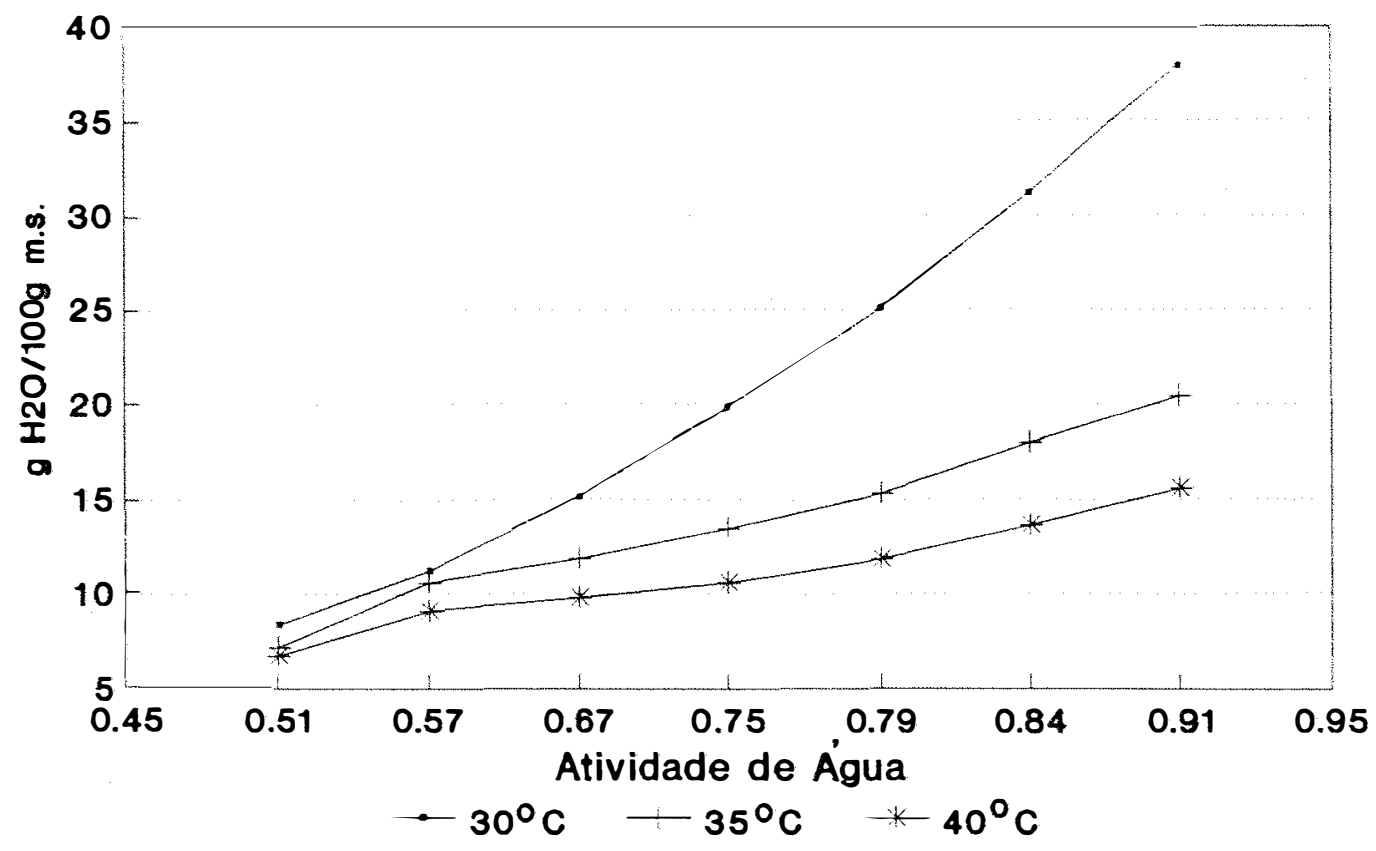

Figura 44. Isotermas parciais de adsorção de farinha de mandioca reciclada a $30^{\circ} \mathrm{C}$, $35^{\circ} \mathrm{C}$ e $40^{\circ} \mathrm{C}$.

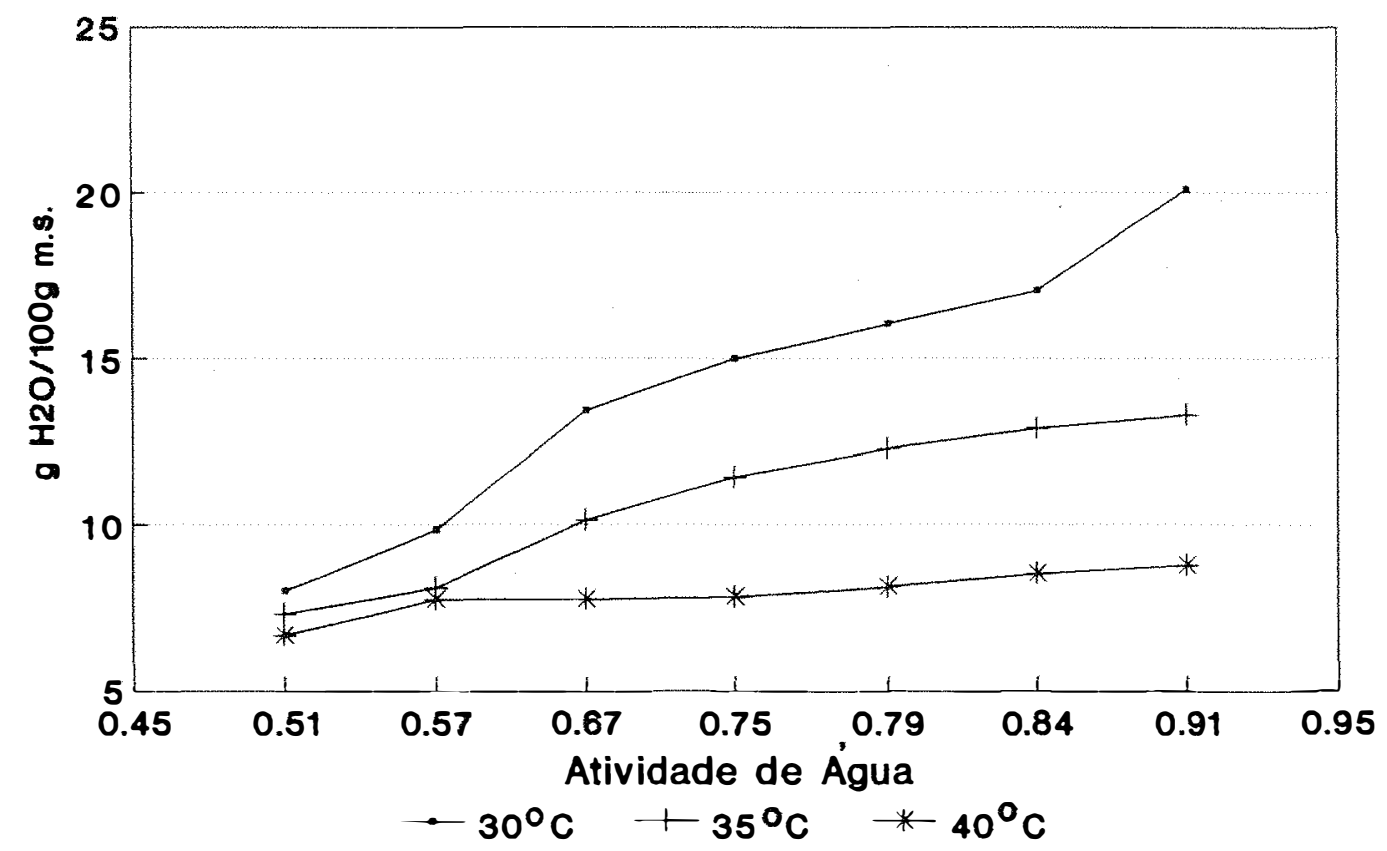

Figura 45. Isotermas parciais de adsorção de farinha de mandioca não reciclada a $30^{\circ} \mathrm{C}$, $35^{\circ} \mathrm{C}$ e $40^{\circ} \mathrm{C}$. 


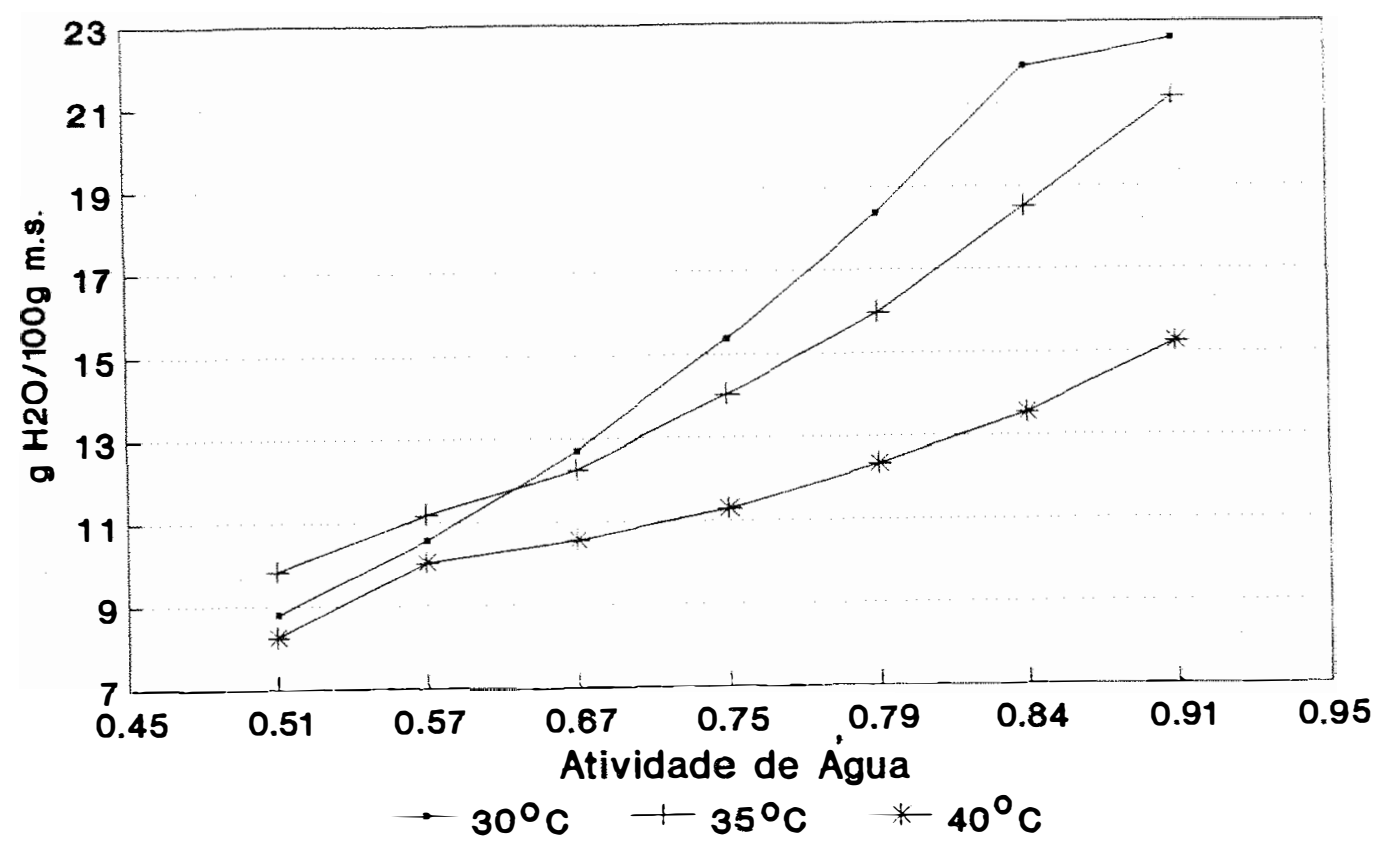

Figura 46. Isotermas parciais de adsorção de farinha integral de soja Céu Azul reciclada a $30^{\circ} \mathrm{C}, 35^{\circ} \mathrm{C}$ e $40^{\circ} \mathrm{C}$.

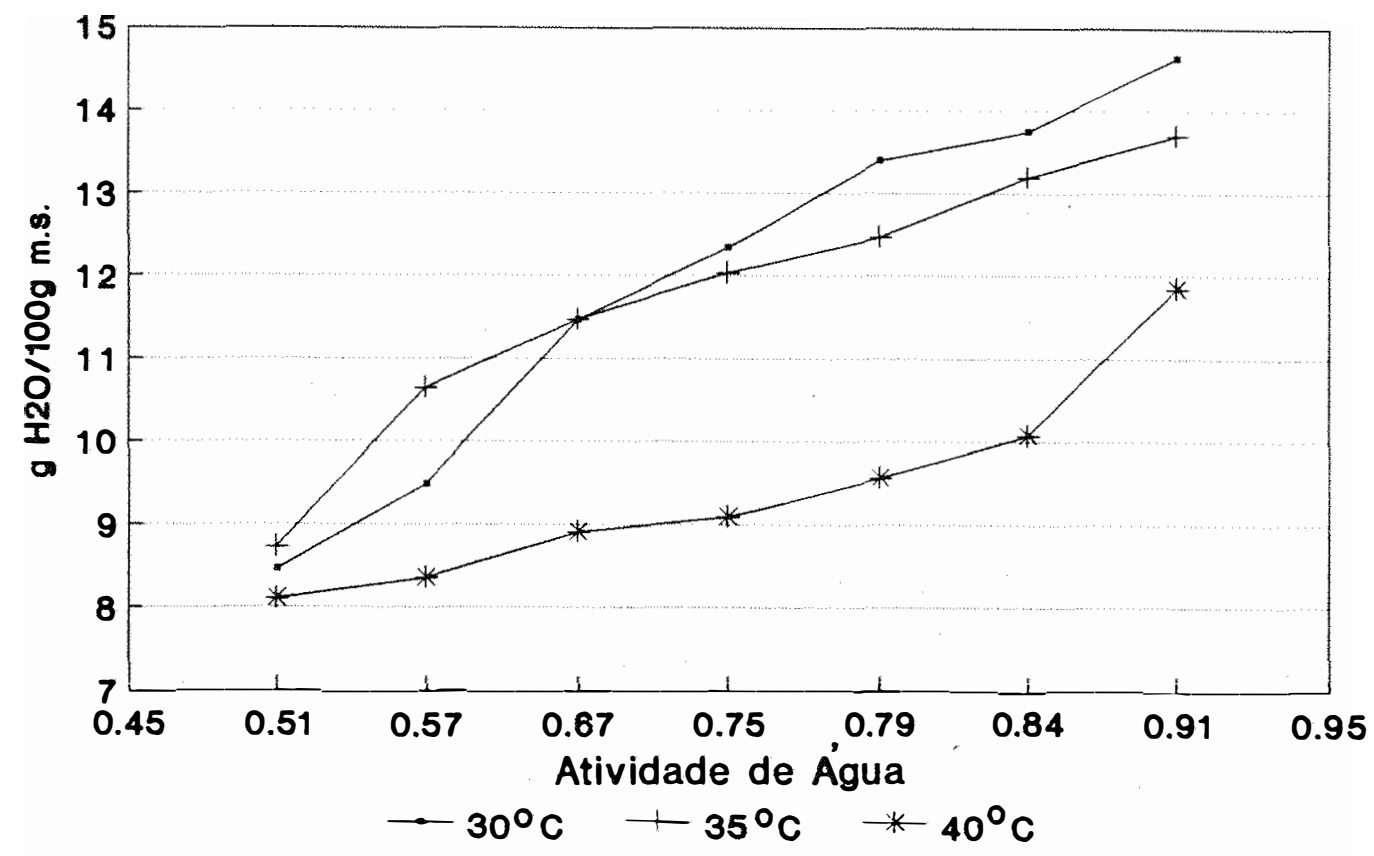

Figura 47. Isotermas parciais de adsorção de farinha integral de soja Céu Azul não reciclada a $30^{\circ} \mathrm{C}, 35^{\circ} \mathrm{C}$ e $40^{\circ} \mathrm{C}$. 


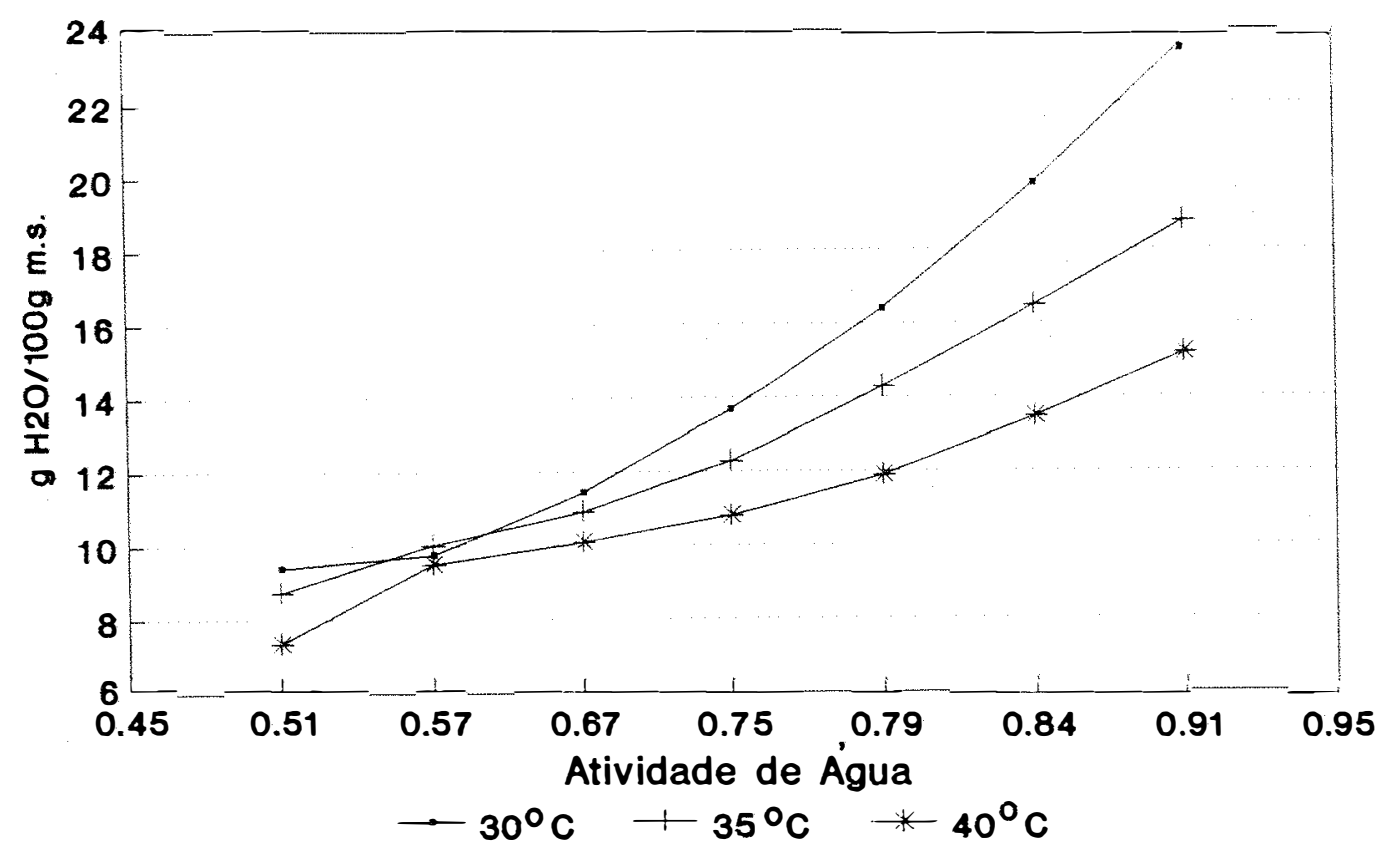

Figura 48. Isotermas parciais de adsorção de farinha de soja sem casca Céu Azul reciclada a $30^{\circ} \mathrm{C}, 35^{\circ} \mathrm{C}$ e $40^{\circ} \mathrm{C}$.

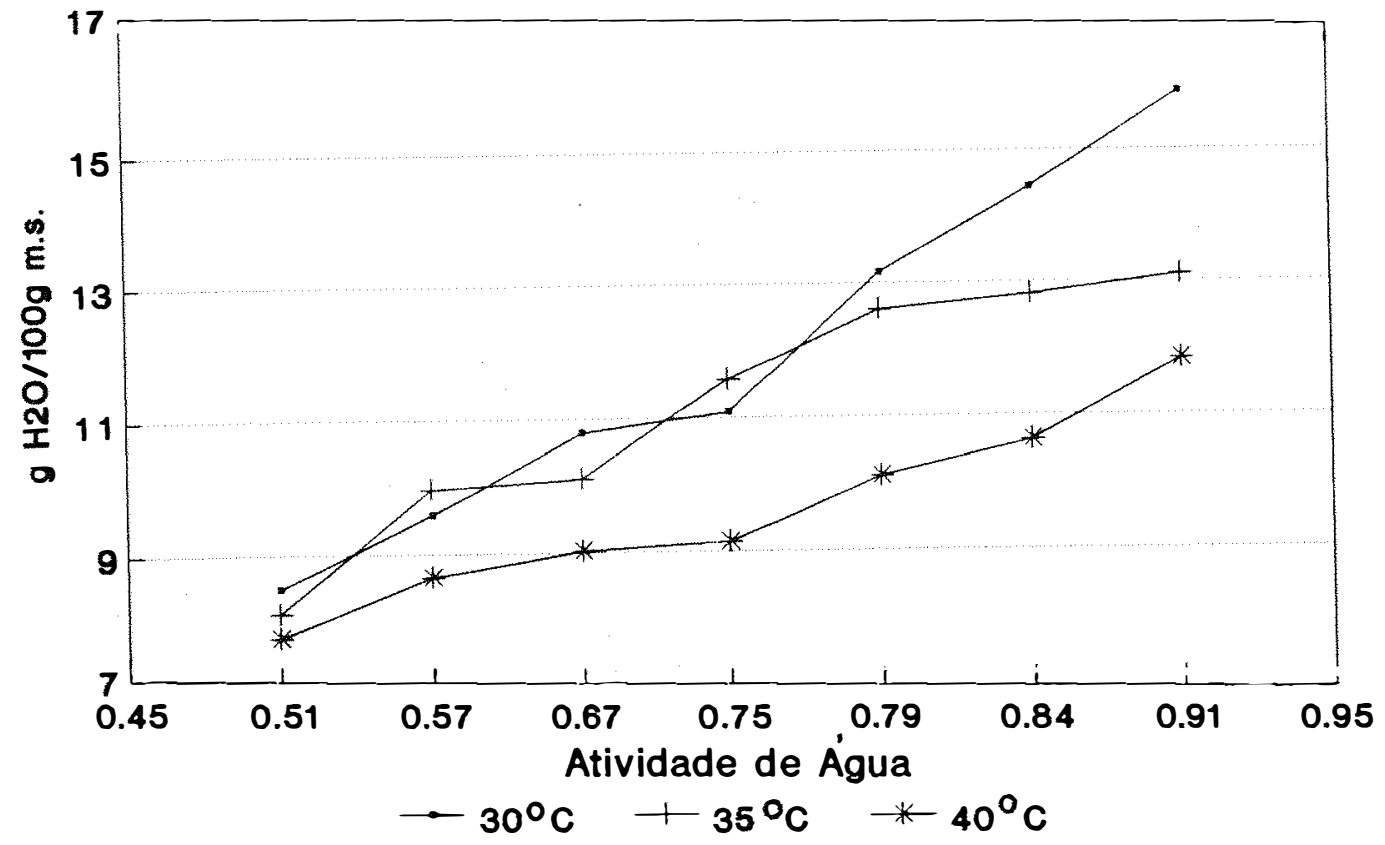

Figura 49. Isotermas parciais de adsorção de farinha de soja sem casca Céu Azul não reciclada a $30^{\circ} \mathrm{C}, 35^{\circ} \mathrm{C}$ e $40^{\circ} \mathrm{C}$. 


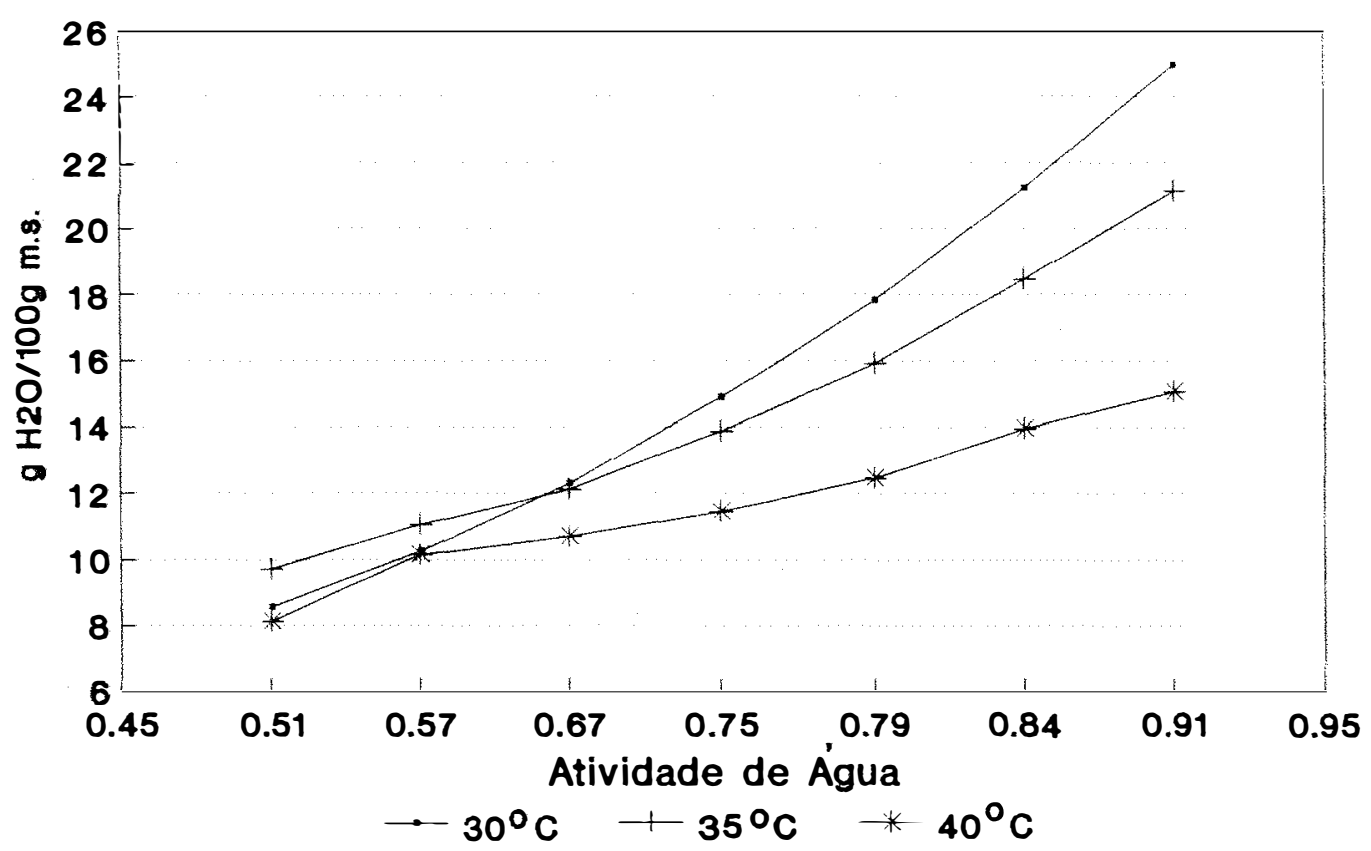

Figura 50. Isotermas parciais de adsorção de farinha integral de soja IAC-08 reciclada a $30^{\circ} \mathrm{C}, 35^{\circ} \mathrm{C}$ e $40^{\circ} \mathrm{C}$.

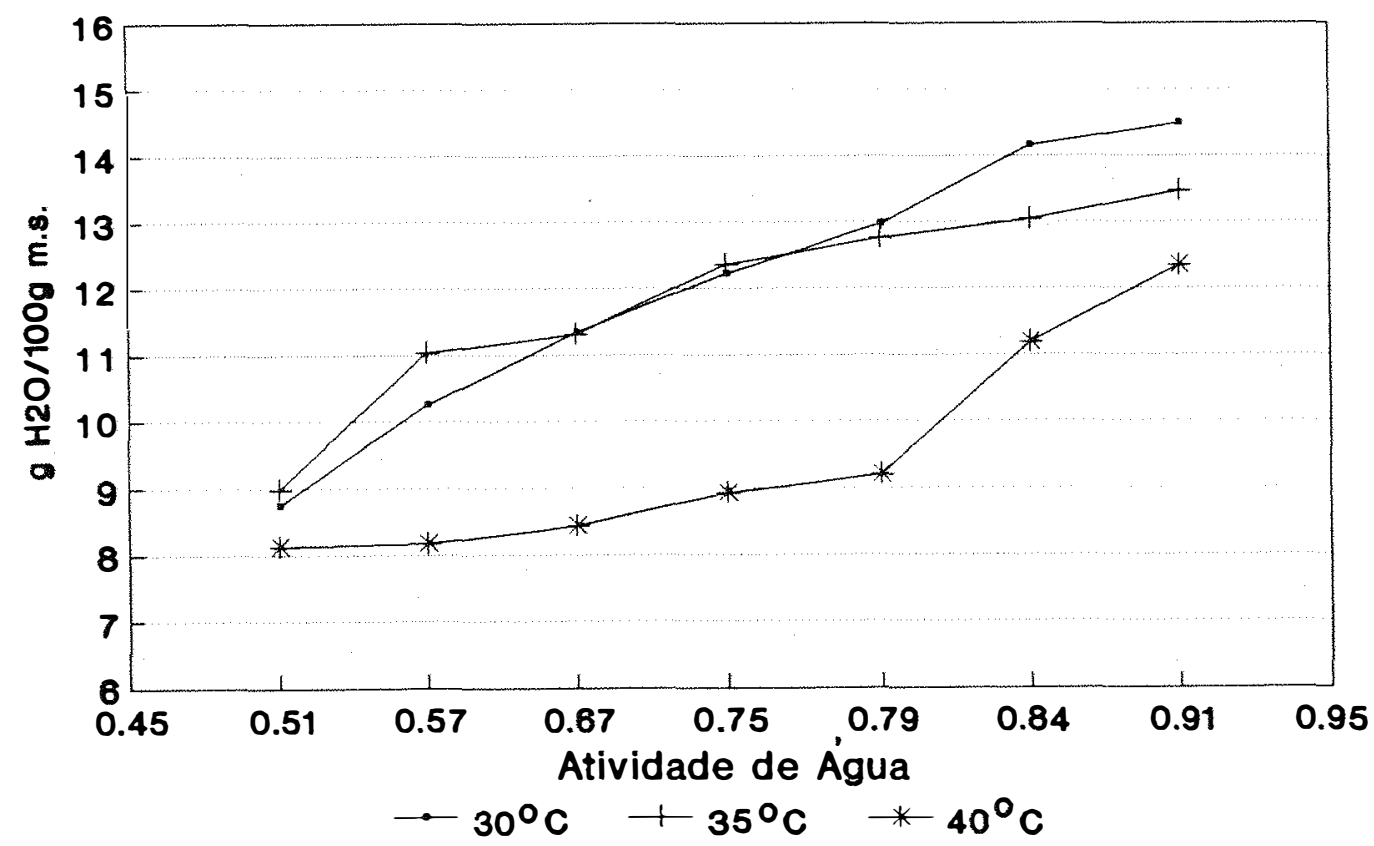

Figura 51. Isotermas parciais de adsorção de farinha integral de soja não reciclada a $30^{\circ} \mathrm{C}, 35^{\circ} \mathrm{C}$ e $40^{\circ} \mathrm{C}$. 


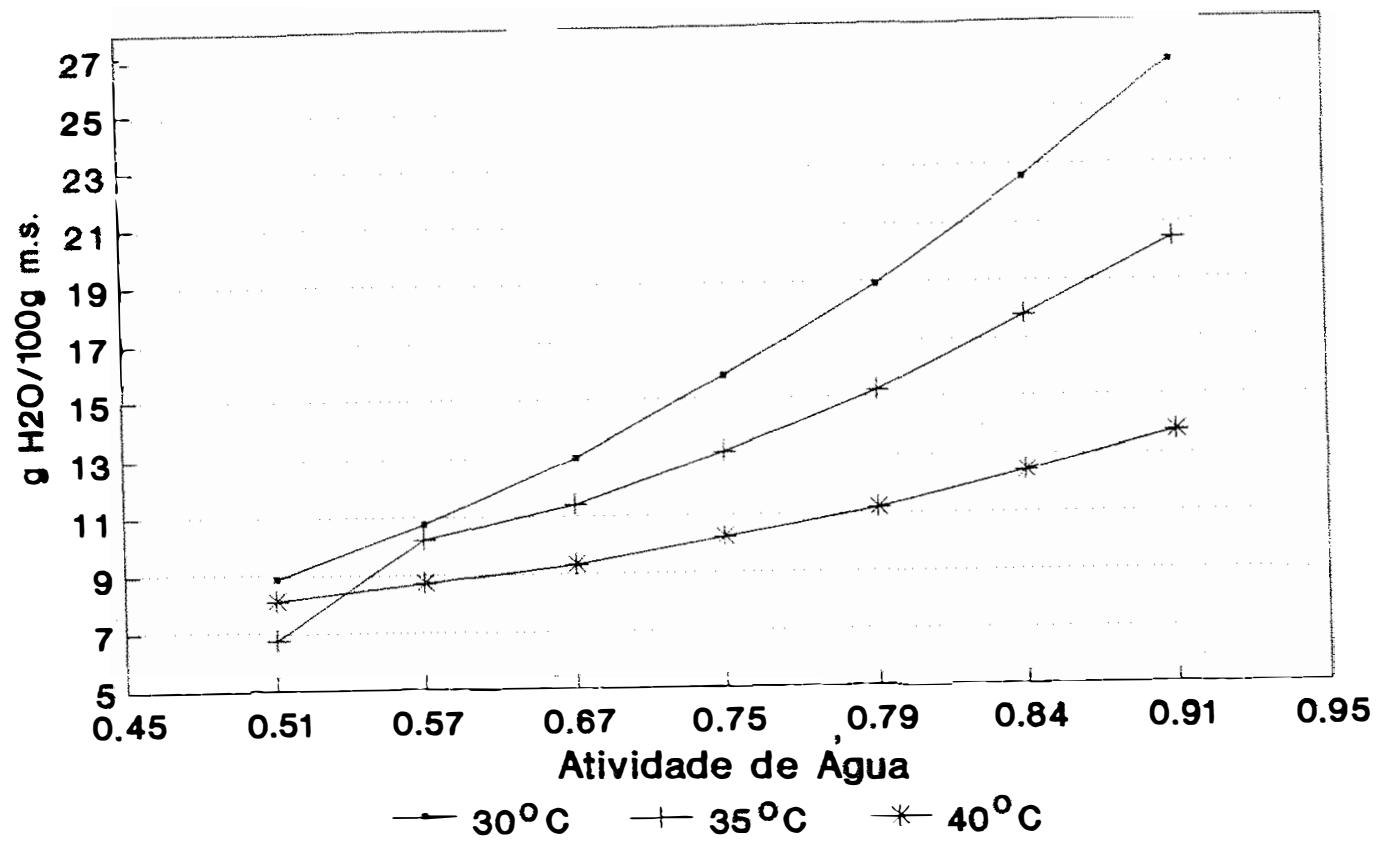

Figura 52. Isotermas parciais de adsorção de farinha de soja sem casca IAC-08 reciclada a $30^{\circ} \mathrm{C}, 35^{\circ} \mathrm{C}$ e $40^{\circ} \mathrm{C}$.

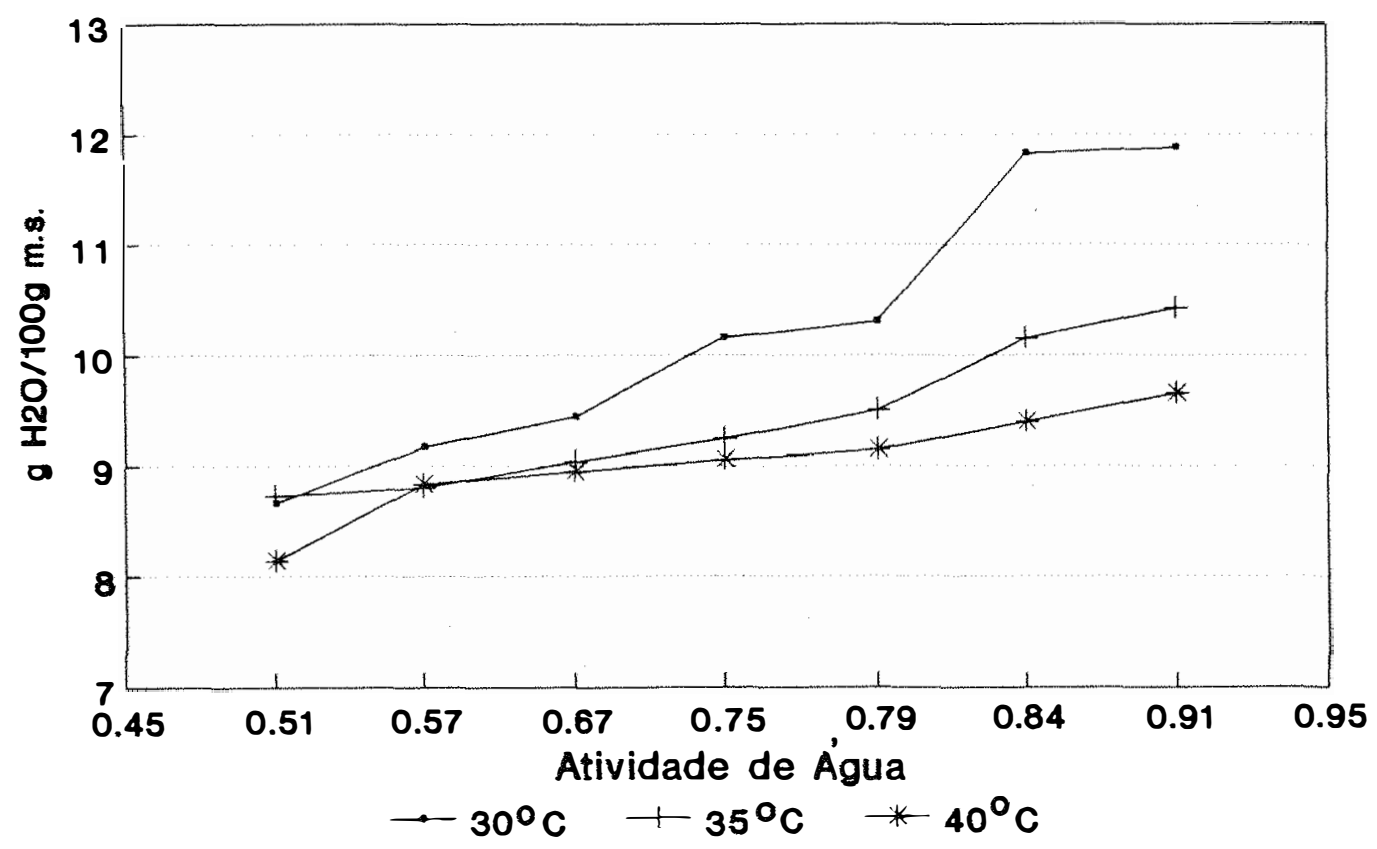

Figura 53. Isotermas parciais de adsorção de farinha de soja sem casca IAC-08 não reciclada a $30^{\circ} \mathrm{C}, 35^{\circ} \mathrm{C}$ e $40^{\circ} \mathrm{C}$. 
Os valores de umidade $\left(\mathrm{g}_{2} \mathrm{O} / 100 \mathrm{~g}\right.$ matéria seca) das amostras recicladas (Figuras $42,44,46,48,50$ e 52 ) foram bem maiores que os valores de umidade das amostras não recicladas (Figuras $43,45,47,49,51$ e 53), isto para as três temperaturas utilizadas e para todas as atividades de água (Tabelas 4 a 21 em anexo).

A partir dessa constatação, foi considerada a possibilidade de alteração das amostras recicladas, que permanecem em ambientes de umidade crescente por um tempo total de 238 horas, contadas a partir do início do equilíbrio à $\mathrm{Aa}=0,51$, Alterações estruturais nas moléculas de amilose e amilopectina traduzem-se, em geral, por uma maior facilidade de hidratação da mesma. Estas alterações podem ser tanto de origem físico-químico como microbiológica.

Embora não tenha sido detectado, visualmente, crescimento microbiano, alterações físicas como: menor friabilidade, menor facilidade de escoamento, aglomeração e aderência às placas, nas amostras recicladas, apontavam para a possibilidade de atividade microbiológica, ao menos incipiente, nas amostras.

A análise microbiológica centrou-se no gênero Bacillus, gênero de bactérias esporuladas amplamente disseminadas na natureza e, frequentemente produtoras de exoenzimas amilolíticas.

A contagem microbiológica (Tabela 3 ) mostrou uma alta incidência do gênero Bacillus, principalmente, nos produtos comerciais farinha de mandioca e fubá Mimoso que foram manipulados em condições usuais da indústria e do comércio. Nas amostras preparadas em laboratório a ocorrência é menor, embora haja uma diferença 
entre amostras recicladas e não recicladas que permanecem apenas 35 horas na umidade mais alta estudada.

Em vista dos resultados obtidos, verifica-se ser inadequado o emprego da mesma amostra para todos os experimentos na faixa de atividades de água estudadas. O método de renovar a amostra a cada nova Aa, ao contrário, permite que os estudos incluam Aa tão alta quanto 0,91. Este último valor excede, em muito, aquele tecnicamente admitido como limite seguro para estocagem de matérias primas e alimentos, que é no máximo, de $\mathrm{Aa}=0,8$.

Além do mais, um valor de $\mathrm{Aa}=0,91$ já está localizado no âmbito de umidade em que alimentos, muito provavelmente, se tornaram higroscópico (KNEULE, 1966; PRADO-FILHO \& GRISOTTO, 1994), sendo suas umidades absolutas, também, funções do tempo de exposição e não, apenas, da umidade do ambiente. Isto significa que com a dilatação do tempo de exposição há um aumento da umidade absoluta, não sendo atingido um equilíbrio verdadeiro. 
Tabela 3. Resultado das Análises Microbiológicas

\begin{tabular}{|c|c|c|c|c|}
\hline Produto & $\begin{array}{l}\text { Tempo de } \\
\text { exposição }\end{array}$ & $30^{\circ} \mathrm{C}$ & $\begin{array}{c}\text { Temperatura } \\
35^{\circ} \mathrm{C}\end{array}$ & $40^{\circ} \mathrm{C}$ \\
\hline $\begin{array}{l}\text { Fubá Mimoso } \\
\text { Recic lado } \\
\text { Não-Reciclado }\end{array}$ & $\begin{array}{r}238 \\
34\end{array}$ & $\begin{array}{l}2,68 \times 10^{8} \text { ufc } \\
1,9 \times 10^{6} \text { ufc }\end{array}$ & $\begin{array}{c}\text { inc } \\
1,21 \times 10^{7} \text { ufc }\end{array}$ & $\begin{array}{l}1,90 \times 10^{7} \text { ufc } \\
1,18 \times 10^{5} \text { ufc }\end{array}$ \\
\hline $\begin{array}{l}\text { Farinha de Mandioca } \\
\text { Reciclado } \\
\text { Não-Reciclado }\end{array}$ & $\begin{array}{c}238 \\
34\end{array}$ & $\operatorname{inc}_{1,54 \times 10^{7} \text { ufc }}$ & $\operatorname{inc}_{1,29 \times 10^{7} \text { ufc }}$ & $\operatorname{inc}_{1,81 \times 10^{6} \text { ufc }}$ \\
\hline $\begin{array}{l}\text { Farinha Integral de } \\
\text { soja Céu Azul } \\
\text { Recic lado } \\
\text { Não-Reciclado }\end{array}$ & $\begin{array}{r}238 \\
34\end{array}$ & $\begin{array}{l}1,17 \times 10^{6} \text { ufc } \\
1,24 \times 10^{5} \text { ufc }\end{array}$ & $\begin{array}{l}1,10 \times 10^{6} \text { ufc } \\
1,41 \times 10^{5} \text { ufc }\end{array}$ & $\begin{array}{l}1,43 \times 10^{6} \text { ufc } \\
1,50 \times 10^{5} \text { ufc }\end{array}$ \\
\hline $\begin{array}{l}\text { Farinha de soja sem } \\
\text { casca Céu Azul } \\
\text { Reciclado } \\
\text { Não-Reciclado }\end{array}$ & $\begin{array}{r}238 \\
34\end{array}$ & $\begin{array}{l}1,87 \times 10^{5} \text { ufc } \\
1,61 \times 10^{4} \text { ufc }\end{array}$ & $\begin{array}{l}1,82 \times 10^{5} \text { ufc } \\
1,40 \times 10^{4} \text { ufc }\end{array}$ & $\begin{array}{l}1,68 \times 10^{6} \text { ufc } \\
1,67 \times 10^{5} \text { ufc }\end{array}$ \\
\hline $\begin{array}{l}\text { Farinha Integral de } \\
\text { soja IAC-08 } \\
\text { Reciclado } \\
\text { Não-Reciclado }\end{array}$ & $\begin{array}{c}238 \\
34\end{array}$ & $\begin{array}{l}2,70 \times 10^{5} \text { ufc } \\
1,63 \times 10^{4} \text { ufc }\end{array}$ & $\begin{array}{l}1,81 \times 10^{5} \text { ufc } \\
1,72 \times 10^{4} \text { ufc }\end{array}$ & $=\operatorname{inc}_{1,71 \times 10^{6} \text { ufc }}$ \\
\hline $\begin{array}{l}\text { Farinha de soja sem } \\
\text { casca IAC-08 } \\
\text { Reciclado } \\
\text { Não-Reciclado }\end{array}$ & $\begin{array}{r}238 \\
34\end{array}$ & $\begin{array}{l}1,81 \times 10^{5} \text { ufc } \\
1,97 \times 10^{4} \text { ufc }\end{array}$ & $\begin{array}{l}1,40 \times 10^{6} \text { ufc } \\
1,32 \times 10^{5} \text { ufc }\end{array}$ & $\begin{array}{l}1,76 \times 10^{8} \text { ufc } \\
1,03 \times 10^{5} \text { ufc }\end{array}$ \\
\hline
\end{tabular}

ufc = unidade formadora de colônias; inc. incontável. 


\section{CONCLUSŌES}

- O equipamento montado, mostrou-se perfeitamente adequado para determinação de valores de equilibrios necessários para o traçado de isotermas parciais de farinhas.

- Os tempos necessários para as farinhas estudadas entrarem em equilíbrio com atividades de água até 0,91 , foram sensivelmente menores quando comparados com métodos de equilibrio estáticos e, mesmo, quando comparados com método de equilíbrio dinâmico com diferente disposição experimental.

- Os resultados obtidos demonstram não ser necessário tomar dados em períodos menores que 10 horas e, maiores que 12 horas a partir do início do experimento de equilibrio de umidades.

- O período necessário de 12 horas, para atingir o equilíbrio em todas atividades de água estudadas nas três temperaturas, $30^{\circ} \mathrm{C}, 35^{\circ} \mathrm{C}$ e $40^{\circ} \mathrm{C}$, permite que se trabalhe com Aa tão altas como 0,91, desde que não se utilize a reciclagem da amostra. 
- A reciclagem de uma mesma amostra para todas atividades de água mostrou-se inadequada, devido às alterações de propriedades físico-químicas e, à proliferação de microrganismos, principalmente, de bactérias esporuladas do gênero Bacillus. 


\section{REFERÊNCIAS BIBLIOGRÁFICAS}

ALVES, R.M.V. \& PADUlA, M. Papel da embalagem na conservação de alimentos sensíveis a umidade, Campinas, CETEA/ITAL, 1992. 8p.

ASSOCIATION OF OFFICIAL ANALYTICAL CHEMISTS. Official methods of analysis. 15 ed. Washington, 1990. v.2. p. 788.

ANAGNOSTOPOULOS, G. Water activity in food. Nutrition and Food Science, London, 59: 6-7, 1979.

AYRANCY, E. Moisture sorption isotherms of dried apricot, fig and raisin at $20^{\circ} \mathrm{C}$ and $36^{\circ}$ C. Journal of Food Science, 55(6): 1591-625, 1990.

BENEDETTI, B.C. \& JORGE, J.T. Curvas de umidade de equilibrio de vários grãos. Ciência e Tecnologia de Alimentos, Campinas, 1(2): 172-88, 1987.

BOBBIO, F.A Introdução à química de alimentos. Campinas, Fundação Cargill, 1985. 232p. 
BOLIN, H.R. Relations of moisture to water activity in prunes and raisins. Journal of Food Science, Chicago, 45, 1190-2, 1980.

CHRISTIAN, J.H.B. Specific solute effects on microbiol/water relation. In: ROCKLAND, L.B. \& STEWART, G.F. ed. Water activity: influences on food quality, London, Academic Press, 1980. p.825-55.

DUCKWORTH, R.B. Water relations of foods, London, Academic Press, 1975. 716.p

FETT, H.M. Water activity determination in foods in the range $0,80-0,99$. Journal of Food Science, Chicago, 38(6): 1097-8, 1973.

GAL, S, Recente advances in techniques for the determination of sorption isotherms. In: DUCKWORTH, R.B. Water relations of foods, London, Academic Press, 1975. p. 139-53.

GUR-ARIEH, B.E.; NELSON, A.I.; STEINBERG, M.P. \& WEI, L.S. A method for rapid determination of moisture-adsorption isotherms of solid particles. Journal of Food Science, Chicago, 30(1): 105-10, 1965. 
KARMAS, E.R. Symposium water in biosystem. Journal of Food Science, Chicago, 38: 736-9, 1973.

KELLOR, R.L. Defatted soy flourand grits. Journal of the American Oil Chemist's Society, Chicago, 51(1): 77-80, 1974.

KIMURA, I.A. Contribuição ao estudo da atividade de água e isotermas de adsorção de umidade em alimentos. São Paulo, 1992. 106p. (Mestrado - Escola Politécnica/USP)

KIMURA, I.A. \& MAEDA, M. Determinação de isotermas de adsorção de umidade: influência da concentração da solução e da variação no volume do recipiente. Boletim da Sociedade Brasileira de Ciência e Tecnologia de Alimentos, São Paulo, 27(2): 79-87, jul./dez., 1993.

KNEULE, F. El secado, URMO, Bilbao, 1966. 414p.

KONTOMINAS, M.G. Moisture adsorption behavoir of paste products. LebensmittlWissenschaft \& Techologie, London, 26(6)-512-6, 1993.

LABUZA, T.P. Water content and stability of low moisture and intermediate-moisture foods. Food Techonology, Chicago, 24: 35-42, 1970. 
LANDROCK, A.H. \& PROCTOR, B.E. A new graphical interpolation method for obtaing equilibria data, with special reference to its role in food pacaging studies. Food Technology, Chicago, 5(8): 332-7, 1951.

LEITĀO, M.F.F.; MAGLER, L.C.S.M.; MAGLER, A.N.; MENEZES, T.J.D. Tratado de microbiologia, São Paulo, Makale, 1987. v.1., 186p.

LEUNG, K.M. Structure and properties if water. Cereal Foods World, Chicago, 26(7): 350-2, 1981.

LONCIN, M.; BIMBENET, J.J. \& LENGES, J. Influence of the activity of water on spoilage of foodstruffs. Journal of Food Technology, Oxford, 3: 131-42, 1968.

PARK, K.J. Curvas de equilibrio higroscópio de três genótipos de grão-de-bico (Cicer arietinum, L). Coletânea do Instituto de Tecnologia de Alimentos, Campinas, 22(2): 209-16, jul./dez., 1992.

PITOMBO, R.N.M.; SPRING, C.; VITOLO, M. Effect of moisture content on the invertase activity of freeze-dried S. cerevisiae. Cryobiology, New York, volume, fascículo páginas, 1993. 
PRADO FILHO, L.G.; GRISOTTO, R. Método simplificado de determinação de isotermas localizadas de adsorção de águas. Boletim do Sociedade Brasileira de Ciência e Tecnologia de Alimentos, Campinas, 28(1): 10-7, 1994.

PRADOFILHO, L.G. \& SABBAGH, M. Equipamento experimental para determinação de isotermas de adsorção pelo método dinâmico. Scientia Agricola, Piracicaba, 50(3): 455-459, out./dez., 1993.

PRIOR, B.H. Measurement of water activity in foods a review. Journal of Food Protection, Ames, 42(8): 668-74, 1979.

QUAST, D,G, \& TEIXEIRA NETO, R.O. Atividade de água em alguns alimentos de teor intermediários de umidade. Coletânea do Instituto de Tecnologia de Alimentos, Campinas, 6(1): 203-32, 1975.

SABBAGH, M. Umidade relativa de equilibrio e oxidação de lipídios em farinhas de castanha do Pará, macadâmia e soja. Piracicaba, 1985 (Mestrado - Escola Superior de Agricultura "Luiz de Queiroz" - USP).

SALTMARCH, M.; LABUZA, T.P. Influence of relative humidity on the physicochemical state of lactose in spraydried sweet whaypowders. Journal of Food Science, Chicago, 45: 1231-6, 1242, 1980. 
SCOTT, V.N.; BERNARD, D.T. Influence of temperature on the measurement of water activity of food and salt system. Journal of Food Science, Chicago, 48: $552-4,1983$.

SMITH, A.K. \& CIRCLE, S.J. Soybeans: chemistry and technology. London, The AVI Publ, 1972. 470p.

SMITH, P.R. The determination of equilibrium relative humidity a water sensitivy in foods. A literature review. s.1. B.M.F.I.R.A, 1971.29p. (Scientific and Technical Survey, 70).

SPECK, M.L. Compedium of methods for the microbiological examination of foods. Washington, American Public Health Association, 1976. 701p.

SPIESS, W.E.L.; WOLF, W.R. The results of the COST 90 project on water activity. In: JOWITT, R.; ESCHER, F.; HALLSTROM, B; MEFFERT, H.F.; SPIESS, W.E.L.; VOS, G. Phisical properties of foods. London, Applied Science Publ. 1983. p.65-91.

SPIESS, W.E.L.; WOLF, W.R. Critical evaluation of methods to determine moisture sorption isotherms. In: ROCKLAND, L.B.; BENCHAT, L.R. Water activity. Theory and application to food. New York, Marcel Dekker, 1987, p.215-33. 
TEIXEIRA NETO, R.O. \& QUAST, D.G. Isotermas de adsorção de umidade em alimentos. Coletânea do Instituto de Tecnologia de Alimentos, Campinas, 8: 141-97, 1977.

TROLLER, J.A. Methods to measure water activity. Journal of Food Protection, Ames, 46(2): 129-34, 1983.

UBOLDI-EIROA, M.N. Atividade de água: influênia sobre o desenvolvimento de microrganismos e métodos de determinação em alimentos. Boletim do Unstituto de Tecnologia de Alimentos, Campinas, 18(3): 353-83, jul./set., 1981.

VAN DEN BERG, C. \& BRUIN, A. Water activity and its estimation in food systems. The critical aspects. In: ROCKLAND, L.B. \& STEWART, G.F., ed Water activity: influences on foods quality, London, Academic Press, 1981. p.1-61.

XAVIER, R.L.; ARDITO, E.F.G.; MORAIS, C. Isotermas de adsorção de umidade de blocos salgados prensados e secos de pescado. Coletânea do Intituto de Tecnologia de Alimentos, Campinas, 16: 81-92, 1986. 


\section{ANEXO 1}

Tabela 1. Fubá Mimoso $30^{\circ} \mathrm{C}$.

$\mathrm{g} \mathrm{H}_{2} \mathrm{O} / 100 \mathrm{~g}$. m.s. no equilíbrio

\begin{tabular}{ccc}
\hline Aw & Reciclado & Não-Reciclado \\
\hline \multicolumn{3}{c}{ gH $_{2} \mathrm{O} /$ l00g. m.s. } \\
0,51 & 8,40 & $\mathbf{8 , 4 0}$ \\
0,57 & 11,89 & 10,83 \\
0,67 & 13,37 & 12,54 \\
0,75 & 15,89 & 13,61 \\
0,79 & 18,94 & 15,03 \\
0,84 & 22,21 & 15,43 \\
0,91 & 25,79 & 17,79 \\
\hline
\end{tabular}

Tabela 3. Fubá Mimoso $40^{\circ} \mathrm{C}$.

$\mathrm{g} \mathrm{H}_{2} \mathrm{O} / 100 \mathrm{~g}$. m.s. no equilíbrio

\begin{tabular}{ccc}
\hline Aw & Reciclado & Não-Reciclado \\
\hline & \multicolumn{2}{c}{ gH $_{2} \mathrm{O} / 100$ g. m.s. } \\
0,51 & 7,29 & 7,29 \\
0,57 & 9,13 & 8,45 \\
0,67 & 10,03 & 9,47 \\
0,75 & 11,29 & 10,14 \\
0,79 & 12,85 & 10,36 \\
0,84 & 14,92 & 11,07 \\
0,91 & 17,34 & 11,38 \\
\hline
\end{tabular}

Tabela 5. Farinha de Mandioca $35^{\circ} \mathrm{C}$. $\mathrm{g} \mathrm{H}_{2} \mathrm{O} / 100$ g. m.s. no equilibrio

\begin{tabular}{ccc}
\hline Aw & Reciclado & Não-Reciclado \\
\hline \multicolumn{3}{c}{$\mathrm{gH}_{2} \mathrm{O} / 100$ g. m.s. } \\
0,51 & 7,21 & 7,31 \\
0,57 & 10,64 & 8,08 \\
0,67 & 11,86 & 10,14 \\
0,75 & 13,46 & 11,42 \\
0,79 & 15,35 & 12,28 \\
0,84 & 17,97 & 12,88 \\
0,91 & 20,44 & 13,28 \\
\hline
\end{tabular}

Tabela 2. Fubá Mimoso $35^{\circ} \mathrm{C}$. $\mathrm{g} \mathrm{H}_{2} \mathrm{O} / 100 \mathrm{~g}$. m.s. no equilibrio

\begin{tabular}{lcc}
\hline Aw & Reciclado & Não-Reciclado \\
\hline \multicolumn{3}{c}{ gH $_{2} \mathrm{O} / 100$ g. m.s. } \\
0,51 & 7,56 & 7,56 \\
0,57 & 9,58 & 9,58 \\
0,67 & 10,55 & 10,33 \\
0,75 & 12,17 & 10,61 \\
0,79 & 14,02 & 10,88 \\
0,84 & 16,37 & 11,67 \\
0,91 & 18,79 & 12,51 \\
\hline
\end{tabular}

Tabela 4. Faninha de Mandioca $30^{\circ} \mathrm{C}$. g $_{2} \mathrm{O} / 100$ g. m.s. no equilibrio

\begin{tabular}{ccc}
\hline Aw & Reciclado & Não-Reciclado \\
\hline \multicolumn{3}{c}{ gH $_{2} \mathrm{O} / 100$ g. m.s. } \\
0,51 & 8,00 & 8,00 \\
0,57 & 11,25 & 9,32 \\
0,67 & 15,10 & 13,41 \\
0,75 & 19,76 & 14.96 \\
0,79 & 25,06 & 16,20 \\
0,84 & 31,22 & 17,03 \\
0,91 & 38,01 & 20,08 \\
\hline
\end{tabular}

Tabela 6. Faninha de Mandioca $40^{\circ} \mathrm{C}$ $\mathrm{g} \mathrm{H}_{2} \mathrm{O} / 100$ g. m.s. no equilibrio

\begin{tabular}{ccc}
\hline Aw & Reciclado & Não-Reciclado \\
\hline \multicolumn{3}{c}{$\mathrm{gH}_{2} \mathrm{O} / 100$ g. m.s. } \\
0,51 & 6,74 & 6,66 \\
0,57 & 9,15 & 7,73 \\
0,67 & 9,77 & 7,74 \\
0,75 & 10,60 & 7,81 \\
0,79 & 11,85 & 8,12 \\
0,84 & 13,62 & 8.52 \\
0,91 & 15,59 & 8,77 \\
\hline
\end{tabular}


Tabela 7. Faninha Integral de soja Céu Azul $30^{\circ} \mathrm{C}$. $\mathrm{g} \mathrm{H}_{2} \mathrm{O} / 100$ g. m.s. no equilibrio

\begin{tabular}{lcc}
\hline Aw & Reciclado & Não-Reciclado \\
\hline \multicolumn{3}{c}{ gH $_{2} \mathrm{O} / 100$ g. m.s. } \\
0,51 & 8,78 & 8,46 \\
0,57 & 10,57 & 9,49 \\
0,67 & 12,69 & 11,46 \\
0,75 & 15,35 & 12,34 \\
0,79 & 18,36 & 13,40 \\
0,84 & 21,91 & 13,75 \\
0,91 & 24,32 & 14,64 \\
\hline
\end{tabular}

Tabela 9. Faninha Integral de soja Céu Azul $40^{\circ} \mathrm{C}$. $\mathrm{g} \mathrm{H}_{2} \mathrm{O} / 100$ g. m.s. no equilibrio

\begin{tabular}{ccc}
\hline Aw & Reciclado & Não-Reciclado \\
\hline & $\mathrm{gH}_{2} \mathrm{O} / 100 \mathrm{~g}$. m.s. \\
0,51 & $\mathbf{8 , 2 5}$ & $\mathbf{8 , 1 0}$ \\
0,57 & 10,03 & 8,36 \\
0,67 & 10,57 & 8,91 \\
0,75 & 11,28 & 9,09 \\
0,79 & 12,34 & 9,57 \\
0,84 & 13,55 & 10,07 \\
0,91 & 15,24 & 11,84 \\
\hline
\end{tabular}

Tabela 11. Faninha de soja sem casca Céu Azul $35^{\circ} \mathrm{C}$. $\mathrm{g} \mathrm{H}_{2} \mathrm{O} / 100 \mathrm{~g}$. m.s. no equilibrio.

\begin{tabular}{lcc}
\hline Aw & Reciclado & Não-Reciclado \\
\hline & $\mathrm{gH}_{2} \mathrm{O} / 100$ g. m.s. \\
0,51 & $\mathbf{3} 12$ & $\mathbf{8 , 1 2}$ \\
0,57 & 10,03 & 9,97 \\
0,67 & 10,91 & 10,11 \\
0,75 & 12,27 & 11,57 \\
0,79 & 14,27 & 12,60 \\
0,84 & 16,47 & 12,81 \\
0,91 & 17,26 & 13,10 \\
\hline
\end{tabular}

Tabela 8. Faninha Integral de soja Céu Azul $35^{\circ} \mathrm{C}$ $\mathrm{g} \mathrm{H}_{2} \mathrm{O} / 100 \mathrm{~g}$. m.s. no equilibrio

\begin{tabular}{ccc}
\hline Aw & Reciclado & Não-Reciclado \\
\hline \multicolumn{2}{c}{ gH $_{2} \mathrm{O} / 100$ g. } & m.s. \\
0,51 & 8,70 & 8,73 \\
0,57 & 11,18 & 10,64 \\
0,67 & 12,26 & 11,47 \\
0,75 & 14,02 & 12,04 \\
0,79 & 15,97 & 12,47 \\
0,84 & 18,53 & 13,19 \\
0,91 & 21,17 & 13,70 \\
\hline
\end{tabular}

Tabela 10. Faninha de soja sem casca Céu A zul $30^{\circ} \mathrm{C}$. $\mathrm{g} \mathrm{H}_{2} \mathrm{O} / 100 \mathrm{~g}$. m. s. no equilibrio

\begin{tabular}{lcc}
\hline Aw & Reciclado & Não-Reciclado \\
\hline & \multicolumn{2}{c}{ gH $_{2} \mathrm{O} / 100$ g. m.s. } \\
0,51 & 8,39 & 8,48 \\
0,57 & 9,76 & 9,58 \\
0,67 & 11,44 & 10,79 \\
0,75 & 13,66 & 11,08 \\
0,79 & 16,37 & 13,16 \\
0,84 & 19,77 & 14,43 \\
0,91 & 23,60 & 15,85 \\
\hline
\end{tabular}

Tabela 12. Faninha de soja sem casca Céu Azul $40^{\circ} \mathrm{C}$. $\mathrm{g} \mathrm{H}_{2} \mathrm{O} / 100 \mathrm{~g}$. m.s. no equilibrio

\begin{tabular}{ccc}
\hline Aw & Reciclado & Não-Reciclado \\
\hline & $\mathrm{gH}_{2} \mathrm{O} / 100$ g. m.s. \\
0,51 & 7,75 & 7,75 \\
0,57 & 9,50 & 8,64 \\
0,67 & 10,10 & 9,03 \\
0,75 & 10,79 & 9,14 \\
0,79 & 11,89 & 10,10 \\
0,84 & 13,45 & 10,62 \\
0,91 & 15,18 & 11,83 \\
\hline
\end{tabular}


Tabela 13. Farinha Integral de soja IAC $-0830^{\circ} \mathrm{C}$. $\mathrm{g} \mathrm{H}_{2} \mathrm{O} / 100$ g. m.s. no equilibrio

\begin{tabular}{ccc}
\hline Aw & Reciclado & Não-Reciclado \\
\hline \multicolumn{3}{c}{$\mathrm{gH}_{2} \mathrm{O} / 100$ g. m.s. } \\
0,51 & 8,74 & 8,74 \\
0.57 & 10,26 & 10,25 \\
0,67 & 12,29 & 11,34 \\
0,75 & 14,88 & 12,22 \\
0,79 & 17,82 & 12,97 \\
0.84 & 21,20 & 14,15 \\
0,91 & 24,94 & 14,49 \\
\hline
\end{tabular}

Tabela 15. Farinha Integral de soja IAC $-0840^{\circ} \mathrm{C}$. $\mathrm{g} \mathrm{H}_{2} \mathrm{O} / 100$ g. m.s. no equilibrio

\begin{tabular}{ccc}
\hline Aw & Reciclado & Não-Reciclado \\
\hline \multicolumn{3}{c}{$\mathrm{gH}_{2} \mathrm{O} / 100 \mathrm{~g}$. m.s. } \\
0,51 & 8,13 & 8,13 \\
0,57 & 10,16 & 8,18 \\
0,67 & 10,69 & 8,44 \\
0,75 & 11,46 & 8,93 \\
0,79 & 12,46 & 9,21 \\
0,84 & 13,96 & 11,18 \\
0,91 & 15,05 & 12,35 \\
\hline
\end{tabular}

Tabela 14. Farinha Integral de soja IAC $-10835^{\circ} \mathrm{C}$. $\mathrm{g} \mathrm{H}_{2} \mathrm{O} / 100 \mathrm{~g}$. m.s. no equilibrio

\begin{tabular}{ccc}
\hline Aw & Reciclado & Não-Reciclado \\
\hline \multicolumn{3}{c}{$\mathrm{gH}_{2} \mathrm{O} / 100$ g. m.s. } \\
0,51 & 8,98 & 8,98 \\
0,57 & 11,05 & 11,04 \\
0,67 & 12,11 & 11,31 \\
0,75 & 13,88 & 12,36 \\
0,79 & 15,91 & 12,76 \\
0,84 & 18,47 & 13,04 \\
0,91 & 21,13 & 13,46 \\
\hline
\end{tabular}

Tabela 16. Farinha de soja sem casca IAC $-0830^{\circ} \mathrm{C}$. $\mathrm{g} \mathrm{H}_{2} \mathrm{O} / 100$ g. m.s. no equilibrio

\begin{tabular}{lcc}
\hline Aw & Reciclado & Não-Reciclado \\
\hline & \multicolumn{2}{c}{ gH $_{2} \mathrm{O} / 100$ g. m.s. } \\
0,51 & 8,88 & 8,66 \\
0,57 & 10,72 & 9,17 \\
0,67 & 13,00 & 9,44 \\
0,75 & 15,77 & 10,16 \\
0,79 & 18,89 & 10,30 \\
0,84 & 22,56 & 11,83 \\
0,91 & 26,59 & 11,88 \\
\hline
\end{tabular}

Tabela 17. Farinha de soja sem casca IAC $-0835^{\circ} \mathrm{C}$. $\mathrm{g} \mathrm{H}_{2} \mathrm{O} / 100 \mathrm{~g}$. m.s. no equilibrio

\begin{tabular}{ccc}
\hline Aw & Reciclado & Não-Reciclado \\
\hline \multicolumn{3}{c}{ gH $_{2} \mathrm{O} / 100$ g. ms. } \\
0,51 & 8,65 & 8,73 \\
0,57 & 10,21 & 8,80 \\
0,67 & 11,40 & 9,04 \\
0,75 & 13,17 & 9,24 \\
0,79 & 15,22 & 9,50 \\
0,84 & 17,80 & 10,15 \\
0,91 & 20,47 & 11,42 \\
\hline
\end{tabular}

Tabela 18. Farinha de soja sem casca IAC $-0840^{\circ} \mathrm{C}$. $\mathrm{g} \mathrm{H}_{2} \mathrm{O} / 100 \mathrm{~g}$. m.s. no equilibrio

\begin{tabular}{ccc}
\hline Aw & Reciclado & Não-Reciclado \\
\hline \multicolumn{3}{c}{ gH $_{2} \mathrm{O} / 100$ g. m.s. } \\
0,51 & 8,13 & 8,14 \\
0,57 & 8,69 & 8,83 \\
0,67 & 9,31 & 8,95 \\
0,75 & 10,20 & 9,05 \\
0,79 & 11,16 & 9,14 \\
0,84 & 12,40 & 9,65 \\
0,91 & 13,73 & 9,89 \\
\hline
\end{tabular}

